Historic, archived document

Do not assume content reflects current scientific knowledge, policies, or practices. 

$62 \cdot+3$

1922

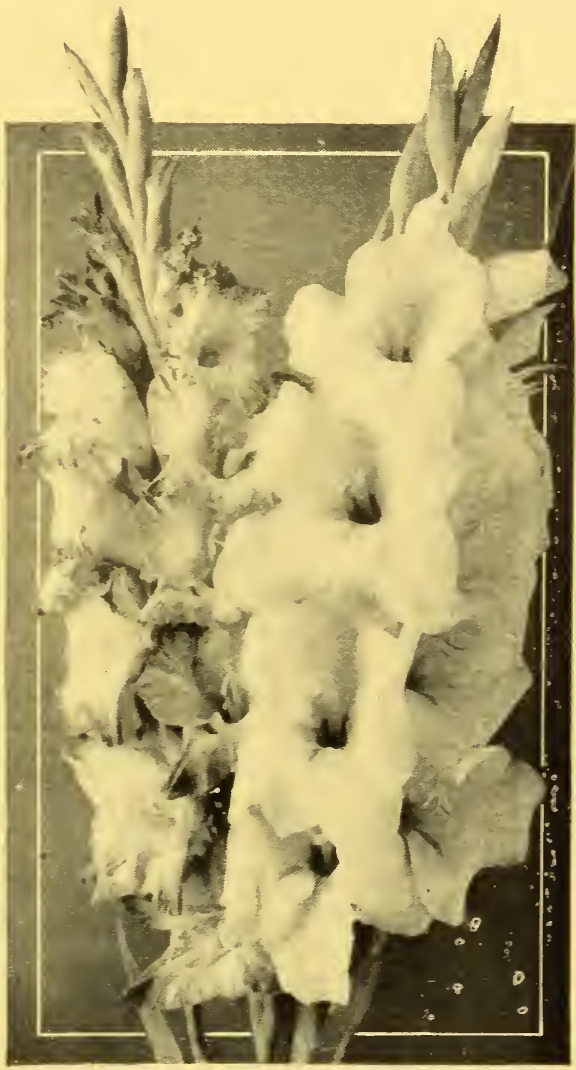

SEEDS

$$
\text { PLANTS }
$$

\section{BULBS}

Emma V. White Company

3010 Aldrich Avenue South

Minneapolis, Minnesota 
The very best oltainable, for our success is assured only by the success our gardner friends have in planting our sceds.

Plan to have a garden-both vegetable and flower-a small plot will furnish fresh vegetables for the table and flowers to embellish and beatify the home. order today.

IIave your seed when ready to plant.

1. We warrant your remittance to reach us if sent by either postoflice or express money order, bank draft or registered letter, but by no other method. You may select extra flower seed to the amount of the cost of sending money by any one of these methods.

If you remit by stamps or silver, it will be at your own risk. If stamps are sent. use one or two cent stamps and do not stick them to rour letter. Canarlian stamps we can't use.

It is comparatively safe to send small amounts of silver, but it should be sewer between pieces of card or blotting paper.

Adr 5 cents for exchange if remitting by personal check.

2. We warrant safe delivery of seeds, provided we receive the order. If you don't receive them promptly, notify us not later than two weeks from the time order was sent; give date and enclose duplicate. Be sure and retain ropy of original order.

You should receive your seeds within three or four rlays of the actual time it takes the mail to come and go between the two points. We aim to fill all orders within 24 hours of their receipt, except plant and bulb orders. See Bull and Plant Pages in regard to these deliveries.

3. We warrant our seeds to be good. No one can guarantee that secrls will grow, nor do we, as so much depends on conditions. Every lot of seed we have is tested for germination ard only stocks of strong viability are offered for sale. Anyone not thoroughly satisfied with germination or products raiser may fecl at liberty to, when placing your order for seeds with us this year, to include such varieties, which will be replaced without charge.

\section{In no manner do we guarantec the crop.}

Warranty does not include seeds of greenhouse plants, which recuire special treatment and care.

Malie new order for seed to he rcplaced, giving date of former order.

\section{PROMIPTESS IS OER MO'T'to Why You Do Not Receive lour Seeds a. No Idress given. We receive many orders without signature or postoffice. Be sure to sign your name and give name of office.}

b. Insullicient address. If there is mail delivery, do not fail to give street or rural delivery number.

c. Indistinct writing. Take special pains to write name and postoffice rery plainly.

d. No title given. Ladies should always give title, Miss or Mrs., especially if initials only are signed.

e. Fault in Postal service. Sometimes letters fail to reach us, and sometimes paskages, even when properly arliressed, are lost or miscarried in the mails. All Bulbs, Plants and Seeds sent prepaid, unless otherwise stated.

\section{TIBIA OF CONTENTS}

Page

Asters ................ $\delta-10$

Fertilizers and Insecticides. Back Cover Flower Seeds .............. 11-3s

Lawn Grass \& Clover Seed..... 39

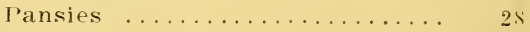

Perennial Seeds ............ $3 \mathrm{~s}$

Plants and Bulbs............ 40-4s

Sweet Peas ............ $35-36$

Vegctable secds ........... 1-7 


\section{SELECT VEGETABLE LIST}

Our vegetable list includes the best standard sorts only. They are of the best stocks, grown by professional growers of national reputation.

All sent Postpaid to any part of the United States or its possessions.

To Canada or other foreign countries, add $10 \mathrm{c}$ for each pound of beans, corn or peas, and add 10 per cent on all regetable seeds.

Price-Packet, 5c. unless otherwise noted.

Special prices to Market Gardeners and Truck Farmers buying large lots of vegetable or flower seeds. Send us a list of your requirements and we will be glad to submit our special quotation.

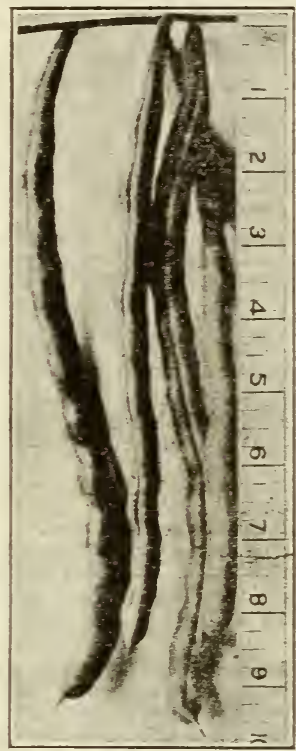

Kentucky Wonder Bean

\section{BEANS}

One pound will plant 50 feet of drill.

Extra Early Refugee. Pods are green, nearly round and produced in great abundance; one of the earliest and best. 1/4 lb., 15e; 1 lb., 40e; 2 lbs., 75 c.

Henderson's Bush Lima. The most popular early Bush Lima. 1/4 1b., 15e; 1 1b., 40c; 2 lbs., 75c.

New Webber Wax. The best wax bean. Very vigorous, healthy and wonderfully productive. Broad, flat golden yellow pods, absolutely free from strings 1,1 b., 15c; 1 lb., 40c.

Round Pod Ixidney Wax. Eariy and heavy yielding; pods long, round and stringless. The best round pod Wax Bean. 1/4 lb., 15e; 1 lb., 40c; 2 lbs., 75c.

Kentuck Wonder Pole, Old Homestead. Earlier than any other green pole bean. The most popular green podded climbing or corn hill bean; productive and good quality. 3/4 1b., 15c; 1 lb., 40c; 2 1bs., 70c.

Early Leviathan, Pole Lima. A very early large podded rariety; the earliest of the large Lima class. Pods 5 to 6 inches long, containing 5 to 6 large, flat white beans. 1/4 lb., 15e; 1 lb., 45e; 2 lbs., 80c.

King of the Garden, Pole Lima. One of the old favorites. $1 / 4$ lb., 15c; 1 lb., 40c; 2 lbs., 70c.

Stringless Green Pod. Early, hardy, vigorous and productive. Pods large, 5 inches long, stout, long and crease-backed, dark green in color; stringless, tender and brittle; good quality. 1/4 lb., 15e; 1 lb., 35e.

\section{BEET}

Detroit Dark Red. One of the very best sorts for home and market garden and canning purposes. Roots uniformly smooth, of medium size, and globe shaped; skin dark red, flesh solid vermillion red. Our special stock of this variety shows little, if any, white zones. Tops are small, upright, dark green shaded red. Packet, 5e; oz., 10e; $1 / 4$ lb., 30c.

Extra Early Egyptian. Grows extra quickly, producing very deep red, turnip-shaped roots. Oz., 15e; $1 / 4$ lb., 35e. Edmand's Blood Turnip. Deep red, very sweet and tender, the standard early sort. Oz., 10; 1/4 1b., 30c.
Beet Iixed. The above three sorts mixed. Oz., 10c; $1 / 4$ lb., 30c.

Swiss Chard, or Spinach Beets. The young leaves make delicious green, and later the large white midribs mas be used as asparagus or for pickles. Oz., 10c; $1 / 4$ lb., 30c.

\section{BEET FOR STOCK}

Giant Sludstrup. A long, redish -yeilow, ovoid root, growing more than half above ground; easily harvested, and by actual test far excels any other variety in weight and feeding value. Oz., 10c; $1 / 4$ 1b., 20c; 1b., 50e. 


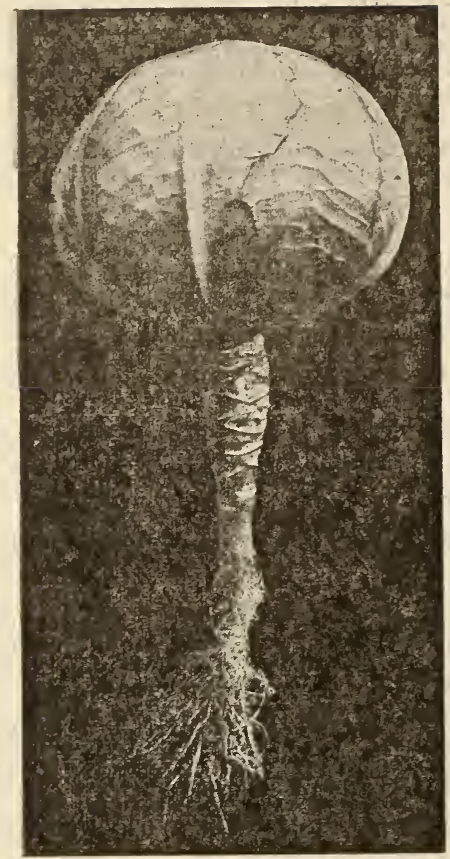

Holland or Danish Ballhead

\section{CABBAGE}

Early Jersey Wakefield. Most popular market strain. 1/4 oz., 10c; oz., 30c. Hollam, or Danish Ball Head. Best winter keeper. 1/4 oz., 10e; 1 oz., 30c. Copenhagen Market. Round, very solid heads: As early as Early Jersey Wakefield and yielding heavier. Very popular.with market gardeners. 1/4 oz., 10e; 1 oz., 30e.

Chinese, or Celery Cabbage. Delicious and more easily grown than the ordinary Cabbage. Use with meats or as a salad. Grow same as lettuce. 1/4 oz., 10e; oz., 30c.

\section{CARROT}

Half Long Scarlet Nantes. Roots 6 to 8 inches long, almost cylindrical, smooth and of deep orange color; very sweet and almost entirely without a core. Packet, 5e; oz., 15e; $1 / 4$ lb., 35c.

Danver's Half-Long. Best main crop variety; half-long, with small tap-root. Oz., 10e; $1 / 4$ lb., 30c.

Oxheart or Guerande. Fine grained and sweet, good for stock or for the table. 1 oz., 10c; $1 / 4$ lb., 30c.

\section{CAULIFLOWER}

Early Snowball. Exceedingly early and one of the surest to make a solid, compact head. Highest grade. Danishgrown seed. Pkt., 10e; $1 / 8$ oz., 40e; $1 / 4$ OZ., T0e; Oz., \$2.25.

\section{CELERY}

Golden Self-Blanching. .Standard yellow blanching. Best French-grown seed. Pkt., 10e; $1 / 4$ oz., 25e; $1 / 2$ oz., 40c.

White Plume. Crisp, self-blanching sort, the earliest variety known. $1 / 4$ oz., 10c; $1 / 2$ oz., 15e. Soak celery seed over night before sowing.

Celeriac or Turnip-Rooted Celery. An improved large type; round, smooth roots. For flavoring and salads. $1 / 2$ oz., 20c.

\section{SWEET CORN}

Mammoth Earliest White Cory. The best variety to plant for extra early. See description page. $1 / 4$ lb., 15c; lb., 35c. Golden Bantam. Try our own grown, it's fine, selected stock 1/4 lb., 15c; lb., 35e.

Peep 0' Day. An excellent white early variety following Mammoth White Cory. $1 / 4$ lb., 15c; 1b., 30c.

Early Evergreen. Ripens 8 to 10 days earlier than Stowell's Evergreen. 1/4 lb., 15e; lb., 35̄e.

Conntry Gentleman or Shoe Peg. A very popular variety which ripens a little earlier than Stowell's Evergreen. Medium sized ears, deep grain in irregular rows and deliciously sweet and tender. 1/4 1b., 15c; lb., s5c.

Black Mexican. An old popular variety, very sweet. Grains white when young. 1/4 lb., 15e; lb., 35e.

\section{POP CORN}

White Rice. $1 / 4$ lb., 10c; lb., 25e.

Golden Queen. 1/4 lb., 10e; lb., 25e.

\section{CRESS}

Pepper Grass, Extra Curled. Used as a garnish. 1/2 oz., 7 c; oz., 10c.

\section{CUCUMBER}

Snow's Perfect Pickling. Just the size and shape for pickles. $1 / 2$ oz., 8c; oz., 12c; $1 / 4$ lb., 35c. 
Improved Long Green. One of the best. for pickles; when ripe, fine for sweet pickles. 1/2 oz., Se; Oz., 12e; $1 / 4$ lb., 35c Early Fortune. The finest type of White Spine yet produced. Early, very productive and disease resistant; fruits nine inches long, slightly tapering flesh white, very firm and crisp, with very few seeds; color, rich dark green Oz., 12e; 1/4 lb., 35c.

Cucumber Iixture, Above mixed. Oz. 10e; $1 / 4$ lb., 30c.

Japanese Climbing. Can be trained on a trellis. The fruits run from 12 ti 16 inches long, and are especially adapted for slicing or salads. $1 / 2 \mathrm{Oz}$. 10e; oz., 15e.

\section{EGG PLANT}

Black Beauty. The best early variety fruits dark purple, holds color for a long time. We consider this the bes variety for market or home garden 1/2 oz., 30e; oz., 50c.

\section{ENDIVE}

Large Green Curled. The most hardy and vigorous sort; leaves bright deep green, with the outer midribs showing trace of rose; readily blanches a creamy white. 1/2 oz., 8c; oz., 15c.

\section{KOHL RABI}

Purple Vienna. A favorite in the old country. It forms a turnip-like bulb above the ground, which is cooked when young and tender. $1 / 2$ oz., 15c; oz., 25c.

\section{LETTUCE}

Black-Seeded Simpson. Leaves curled. inner ones almost white, non-heading. Big Boston. A deservedly popular early Oz., 10c; $1 / 4$ lb., 30e.

variety which thrives in cool weather and stands hot weather equally as well. Large solid heads, hearts bleach a rich yellow, tender and excellent flavor. One of the best for market or home garden. $1 / 2$ oz., 8c; oz., 15c; $1 / 4$ lb., 46e.

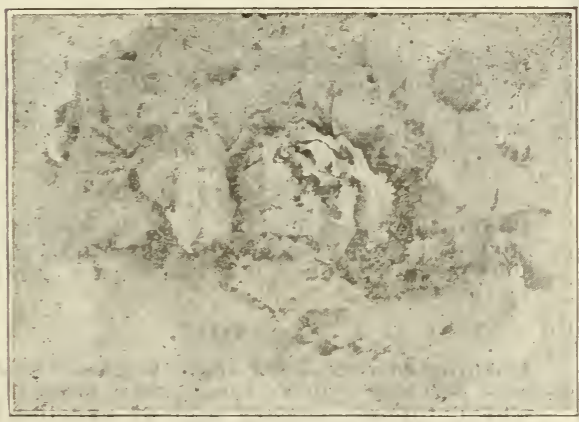

Iceberg Lettuce

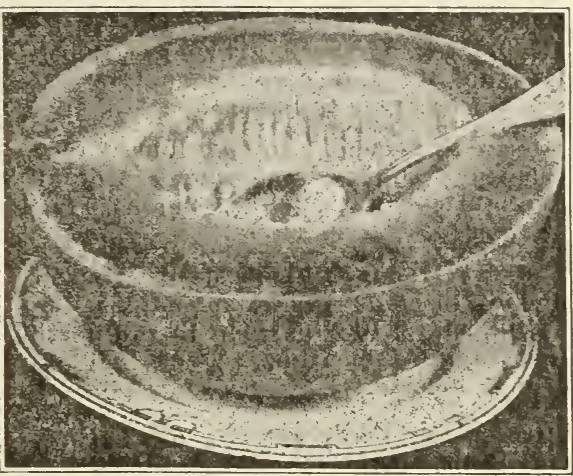

Honey Dew Muskmelon

\section{MUSKMELON}

Burrell's Gem. Like the Rocky Ford in shape but with orange flesh. Fairly melts in the mouth. Oz.,12c; $1 / 4$ lb., 35c. Honey Dew. Delicious and meltingly sweet; large, oval-shaped, with smooth rind, thin skin and unusually thick flesh, of emerald greenish hue. $1 / 2$ oz., 10c; oz., 15c.

EarIy Hackensack. One of the best, earliest, hardiest and most prolific of netted melons; thick, light green flesh of fine flavor. $1 / 2$ oz., 8c; oz., 12c.

Osage, or Miller's Cream. The standard oval sort. Most delicious. Flesh salmon color; very thick. $1 / 2$ oz., 8c; oz., 12c.

Rocky Ford, or Netted Gem. Second earliest, round or slightly oval. Flesh greenish and of luscious flavor. $1 / 2 \mathrm{oz}$., $8 \mathrm{c} ;$ oz., 12e.

\section{LETTUCE (Continued)}

Hanson Head. Sne of the finest Head Lettuces. Inner leaves usually curled and $t w i s t e d .1 / 2$ rz., 8c; oz., 12e; $1 / 4$ lb., 30c.

Grand Rapids. One of the very best leaf lettuces. Leaves finely curled and iplendid for salads. $1 / 2$ oz., 8c; oz., 15c; $1 / 4$ lb., 40c.

Iceberg. Extremély hard heading, with finely indented leaves and center thoroughly blanched. Our grower regards [ceberg and Hanson Head as the best Head Lettuces. Always crisp and tendenr, even in the hottest days of summer. $1 / 2$ oz., 8e; oz., 15e; $1 / 4$ lb., 40c.

l'rize Head. Very popular, large, loose heading sort. Leaves finely fringed, outer ones shaded brown. $1 / 2$ oz., 8c; cz., 10e; $1 / 4$ lb., 30c.

Lettuce Mixture. All the above mixed. $1 / 2$ oz., 8c; oz., 12c; $1 / 4$ lb., 30e. 


\section{WATERMELON}

Cole's Early. Best early and most desirable for northern growing. Excellent quality and very productive. $1 / 2$ oz., 8c; oz., 12c; $1 / 4$ lb., 30c.

Kleckley Sweets. Of luscious flavor, crisp and sugary,-the sweetest of all and quite early. $1 / 2$ oz., 8c; oz., 12c; $1 / 4$ lb., 30c.

Halbert Honey. Flesh deep crimson, and of luscious flavor; splendid seller. Though late, it will ripen in the north if in a good location. $1 / 2$ oz., 8c; oz., 12c; $1 / 4$ lb., 30c.

Citron. For preserves. $1 / 2$ oz., 8c; oz., 12e; $1 / 4$ 1b., 30c.

\section{ONION SEED}

One ounce will

plant 200 feet

of drill; four

pounds in drill

for an acre.

Selected

Sonthport Red

Globe Orion
High Grade

Selected

Strains Oux

Specialty

\section{ONION}

Selected Southport Red Globe. Finest type and most popular of the Red Onions. The bulbs are distinctly globeshaped, with a small neck, excellent keepers; color, a deep purplish-red. Our stock is grown from selected bulbs and we recommend it for market and home garden. Oz., 25c; $1 / 4$ lb., 85c; 1 lb., \$2.75.

Ideal Yellow Globe. An exceedingly handsome large yellow Onion, which is the most globe-shaped we have ever seen. Its general characteristics stamp it as the best main crop variety of its type, and we are pleased to offer it to our customers, feeling sure that it will fully satisfy all who desire to grow large Onions from seed. The bulbs are true globe-shape, with skin of a pleasing yellow color, flesh white and of mild flavor. It is not the ordinary Southport Yellow Globe, but is far superior, much more productive, and we especially recommend it for planting in the home garden. Packet, 5e; oz., 25c; $1 / 4$ lb., 85c; lb., \$3.00.

Mammoth Spanish or Prizetaker. Exterior pale yellow, flesh white. Grow to immense size if seed is sown in hot bed and transplanted. Very productive. $1 / 2$ oz., 15c; oz., 25c; $1 / 4$ lb., 85e; lb., \$3.00.

Red Wethersfield. The very best keeper and one of the most popular for general cultivation. $1 / 2$ oz., 15e; oz., 20 s $1 / 4$ lb., 65c.

Silver skin. Large White Portugal. Early and mild; best for growing sets and pickles. $1 / 2$ oz., 15c; oz., 25c; $1 / 4$ lb., 85e.

\section{ONION SETS}

Plain liberally, for green onions from sets are the first crop ready for the table. Selected, clean, sound stock.

White Bottom, lb., 35e; 5 lbs., \$1.50. Parcel Post Prepaid.

\section{OKRA}

Perkins Long Pod. An exceedingly handsome variety; pods grow 4 to 5 inches long, slim and of a beautiful green color. Dwarf and very productive. Oz., 10c; $1 / 4$ lb., 25c.

\section{PARSLEY}

Champion Moss Curled. Dark, densely curled leaves. Slow in germinating; soak seed 24 hours. $1 / 2$ oz., 8c; oz., 15e; $1 / 4$ lb., 45c.

Prices in Quantity on Application

\section{PARSNIP}

Hollow Crown or Large Sugar. The best variety roots; long, very smooth, white, tender, sugary and of excellent flavor. Oz., 10es $1 / 4$ lb., 30c. 


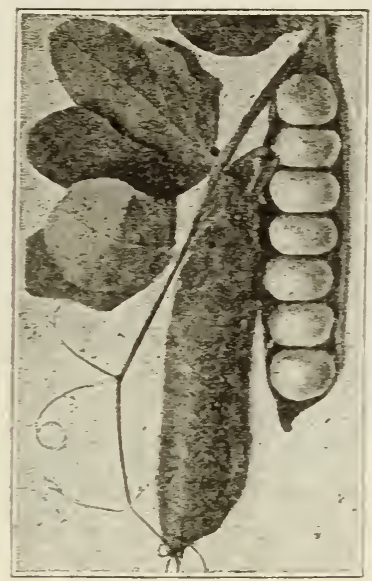

Little Marvel

\section{GARDEN PEAS}

One pound will plant fifty feet of drill.

Alaska or Earliest of All. A sweet, smooth, dark blue pea, the earliest known. 3 oz., 15e; lb., 40c.

Peter Pan. The largest of all the early dwarf varieties. Large, dark green pods, averaging 9 to 10 peas to Dod. Exquisite llavor and mature early. Superior to Gradus. Thos. Laxton or Laxtonian. 3 oz., 15e; lb., $45 \mathrm{c}$.

American Wonder. Most popular early pea; quality excellent: needs no support. 3 oz., $15 \mathrm{c}$; $1 \mathrm{~b} ., 45 \mathrm{c}$.

Little Marvel. Whenever tried, this becomes a permanent feature of the wegetable garden. Fully as early as the American Wonder, while the pods are larger and yield much heavier. 3 oz., 15c; lb., 45c.

Nott's Excelsior. Of compact growth and almost as early as American Wonder. Pods three inches long, with large peas and very sweet. 3 oz., 15c; lib., $45 \mathrm{c}$.

Telephone Improved. Tall growing, long bearing, late sort. Pods very large; flavor delicious. 3 oz., 15c; lb., 45c.

Melting Sugar (Edible Pods). The pods are cut and cooked like beans. Very sweet and tender. 3 oz., 15c: lb., 45c.

\section{PEPPER}

Chinese Giant. Largest and finest red pepper, flesh unusually thick and very mild, and splendid for salads. $1 / 4 \mathrm{oz}$. 30 c.

Pimiento. The sort so much used for salads, flavoring or garnishing; also unequalled for stuffing. Thick skin, "ery mild and delicate. 1/4 oz., 15c.

Red Chili. Small bright red; very hot and pungent. 1/4 oz., 15e; 1/2 oz., 25c.

Ruby King. Most popular, largefruited sort, best for stuffed pickles. 1/4 Oz.. 1Sc.

\section{PUMPKIN}

King of Mammoths. Immense in size and from 100 to 200 pounds in weight. 1 oz.. 15c; 1/4 lb., 45c.

Small Sugar. The famous New England pie pumpkin, sweetest of all. 1 oz., 15c; 1/4 lb., 35c.

\section{VINE PEACH}

For the vegetable garden. Grows simllar to $\mathbf{M u s k m e l o n . ~ F r u i t ~ b r i g h t ~ o r a n g e ~}$ yellow, size of a large peach. For pies, preserves or pickles. 1/2 oz., 15c.

RADISH

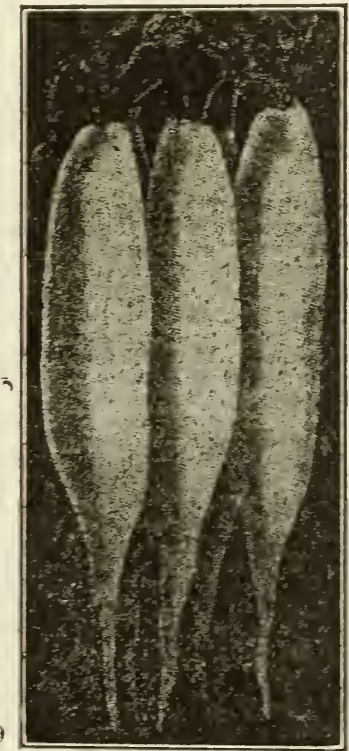

Icicle Radish 


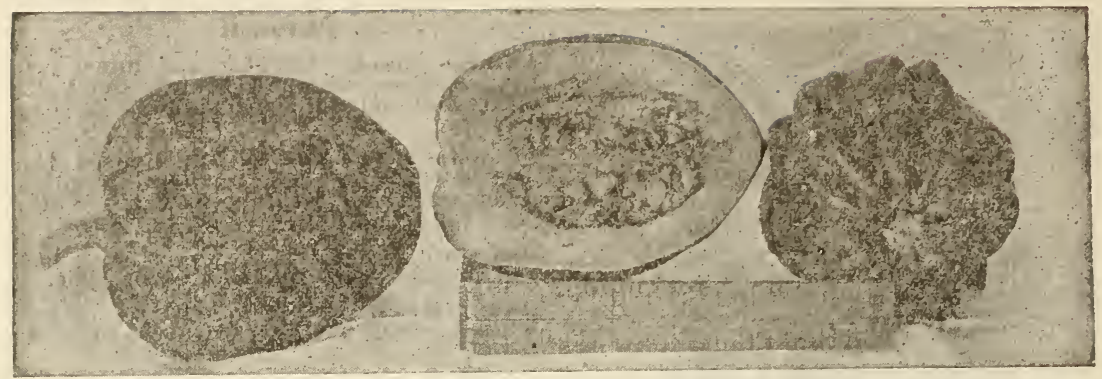

Golden Queen Squash

Vines vigorous and very productive. Fruits's just the right size, averaging 6 to 8 inches long and 4 to. 6 inches in diameter. Color dark green, shell is hard, smooth and is ridged as shown in picture. Culture same as Hubbard, keeps late into the winter.

Also known as the Individual squash for it is served like canteloupe and eaten out of shell with a spoon. To prepare, wash clean, cut in half, remove seeds, bake twenty minutes and you will have the most delicious squash you ever tasted. Splendid for pies. Packet, 8c; 1/2 oz., 15c.

\section{RADISH-SAXA}

The earliest of the forcing radishes. Round, bright scarlet, with an exceedingly small top. Both for forcing and early open ground. Packet, 5e; oz., 15e.

\section{RADISH}

Vick's Scarlet Globe. We have an exceptionally fine stock of this superb variety. It is one of the very earliest of the forcing radishes and does equally well outside; roots are of fair size, globe-shaped and with a small top; always crisp and tender; color, a bright scarlet. Oz., 15c; 1/4 1b., 45c.

Sparkler White Tip. Quite similar to Scarlet Turnip White Tipped as to its size and time of maturity. The white, however, extends further up on the radish; fine looking and excellent quality. Pkt., 5c; oz., 15e; $1 / 4$ lb., 45e.

Crimson Giant. Early, crisp and tender; does not get pithy or hollow. Oz., 10c; $1 / 4$ lb., 35c.

French Breakfast. Scarlet, oliveshaped, white tipped, about two inches long. Very crisp and tender, and of beautiful color. Oz., 10e; $1 / 4$ lb., 30c.

Icicle. A beautiful transparent white radish, crisp and brittle; about three inches long. Oz., 10c; $1 / 4$ lb., 35c.

Radish Mixture. The above five varieties mixed. Oz., 10c; $1 / 4$ lb., 35c.

Long Black Spanish, Winter. Sow about July 10th. Usually run to seed if planted early spring. $1 / 2$ oz., 10c.

\section{SALSIFY OR VEGETABLE OYSTER}

One of the most delicious and nutritious vegetables, it has the true oyster flavor, a delicious and inexpensive substitute for them when used in soup or fried. One ounce will sow 50 feet. Cultivate like parsnips.

Mammoth Sandwich Island. Standard variety. Oz., 20c; $1 / 4$ 1b., 75e.

\section{SPINACH}

Long standing. Best for family use. Oz., 10c; $1 / 4$ 1b., 20c.

\section{SQUASH}

Bush Fordhook. A new Bush Squash suitable for summer or winter use. Fruits are oblong, or 10 inches in length, with thin yellowish skin and thick, straw-colored flesh; unequalled in quality and flavor, and being of bush growth the plants can be grown more closely together. Oz., 12c; $1 / 4$ 1b., 35c.

Delicious. The best flavored squash, unsurpassed for fall and winter. Oz., 15e; $1 / 4$ lb., 45c.

Early Summer Crookneck. Oz., 12e; $1 / 4$ 1b., 40c.

Hubbard. Best winter squash. Oz., 15e; $1 / 4$ 1b., 55c. 


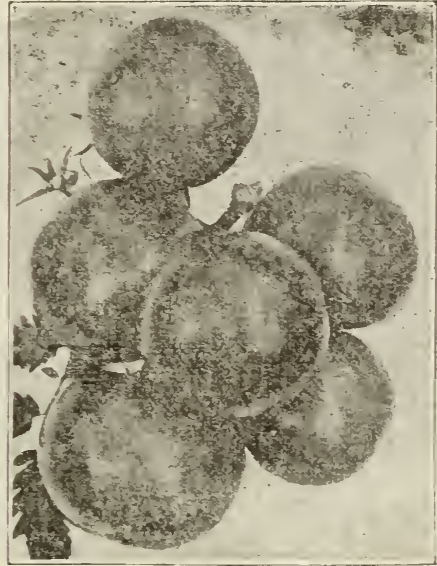

John Baer Tomato

\section{TOMATO}

John Baer. An exceptionally fine early variety, about ten days later than the Earliana; fruit uniformly smooth, round and solid; color, crimson; a good canning sort for the North. On account of the large yield, desirable size and shape, this variety is suited both for early market and home use. $1 / 4$ oz., 12c; $1 / 2$ oz., 20c.

Ear1y June. Said to be "earlier than Earliana, as smooth and handsome as Stone, as solid and spedless as Ponderosa and more prolific than either." Especially valuable for the extreme North. $1 / 4$ oz., 15c; $1 / 2$ oz., 25c; oz.. 45c.

Earliana. For a number of years this ranked as the Earliest Tomato, being equally valuable in size and quality, with solid, smoothefruits and it is still a great favorite. $1 / 4$ Oz., 10c; $1 / 2$ Oz., $18 c$.

Husk, or Ground Cherry. Also called Strawberry Tomato. The small yellow fruits are enclosed in a husk and are much prized for eating, preserving and making pies. $1 / 4$ Oz., 10c; $1 / 2$ Oz., 18c.

Golden Ponderosa. A splendid new yellow Tomato. The large yellow slices make a lovely salad, both in appearance and taste, and it is especially fine for preserving. $1 / 4$ oz., 15e; $1 / 2$ oz., 25e.

\section{TOMATO (Continued)}

Ponderosa. The largest and meatiest Tomato, almost seedless, especially fine quality for slicing. $1 / 4$ oz., 12e; $1 / 2$ oz., 20c.

Small Fruited Tomatoes, Mixed. A mixture of the currant, cherry and pear-shaped sorts in both red and yellow. $1 / 4$ Oz., 12c.

Yellow Pear, Yellow Plum and Red Plum. Each, packet, 5c; $1 / 4$ oz., 12c.

\section{TURNIP}

Improved Purple Top Ruta Baga. It keeps perfectly all winter. Oz., 10c; $1 / 4$ lb., 25e; lb., 75c.

Purple 'Iop Strap-Leaf. One of the best table, and stock turnips. Good cropper; excellent keeper. Oz., 10e; $1 / 4$ 1b., 25e.

Snowball. : The best white turnip, desirable for early sowing. Oz., 10c; $1 / 4$ lb., 25e.

\section{HERB GARDEN}

Price, each, per packet, 5c.

Caraway. Seeds used for flavoring bread, pastry, meats, etc.

Dill. Seeds are used in pickles and for flavoring soups.

Lavender. Flowers used in making perfume.

Rosemary. The leaves are used for seasoning.

Sage. The leaves used in dressings and sauces.

Sweet Fennel. Leaves used for garnish and fish sauces.

sweet Marjoram. Leaves and shoots used for seasoning.

Summer Savory. Used for soups and dressings.

Thyme. Used for seasoning; a tea is also made for nervous headache.

\section{ANNUAL, FLOWER GARDEN COLLECTION}

No. 70-the 7 for 25c.

Seabiosa. Mixed colurs.

Pinks. Mixed colors.

Poppies. Mixed colors.

Asters. Mixed colors.

Early Cosmos. Mixed colors.

Verbina. Mixed colors.

Everlastings. Mixed colors. 


\section{QUEEN OF THE MARKET}

If you want Asters at the earliest possible date, this should be in your purchase, especially if you grow commercially, as the earliest blooms always bring the best prices. It comes from 2 to 4 weeks earlier than any other sort and is besides a handsome flower. Price, pkt., 100 seeds, 5c; 3 pkts., 12c.

\section{Crimson}

Lavender Mixed

Purple

Rose-pink

\section{IMPERIAL DAYBREAK ASTER}

Blossoms are very double and compact, and have always been a favorite with florists, both because of their medium early-flowering period and for their own peculiar beauty. Price, pkt., 75 seeds. 8 c.

Purity Daybreak. Pure white.

Shell-pink Daybreak.

Pale Lavender Daybreak.

Galmon Pink Daybreak.

inixed, All Colors.

\section{PEONY-FLOWERED ASTER}

One of the handsomest sorts, with very double, ball-like flowers, resembling a Peony or some of the new Chrysanthemums. One of my customers said these were among her largest and finest Asters. Price, pkt., 100 seeds, 5c.

\section{Crimson Rose White \\ Blood Red Dark Blue Mixed}

\section{ASTERMUM,}

\section{CONET OR OSTRICH PLUME TYPE}

A splendid new type of the Ostrich Plume Aster, with large Chrysanthemum-like flowers. Pkt., 50 seeds, 5c.

Lavender, Rose Pink, White, Mixed

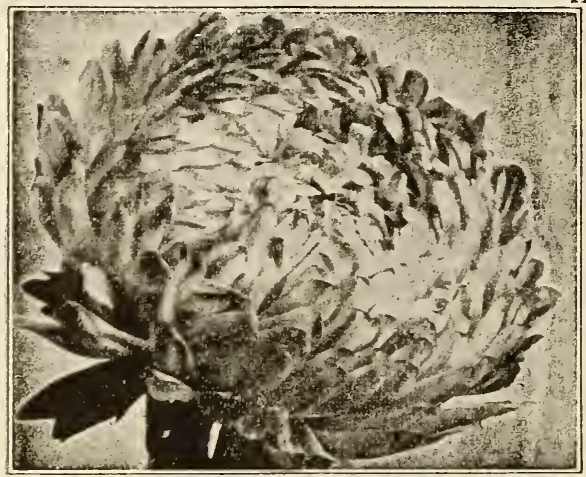

Peony-Flowered Aster

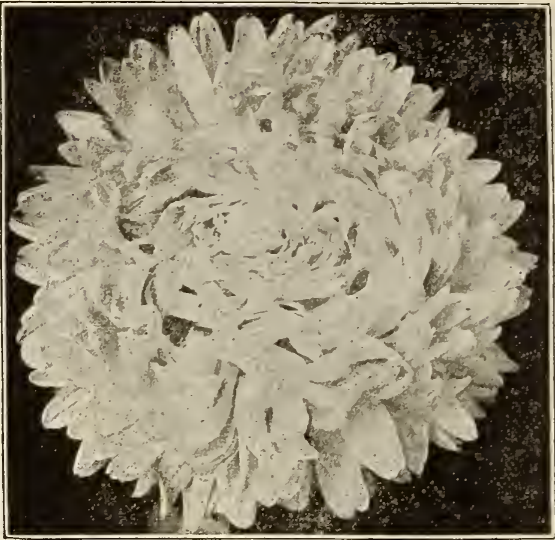

White Perfection Aster

VICK'S CARDINAL ASTER

The best Lavender Aster. Comet form and excelling all other Lavender Asters in its delicate shade. Packet, 50 seeds, 5c.

WHITE PERFECTION ASTER

Best Mid-season White Aster. Vick places this as the finest mid-season White Aster in cultivation. In form it is like the Upright Branching, the plants being tall, with abundant flowers of exquisite shape and very double, the centers strongly whorled, and witb long, strong stems, splendid for cutting. Packet. 50 seeds, 8c.

\section{VICK'S LAVENDER GEM}

A dark red Aster spiêndid for bedding, making a brilliant show from early August till the close of the season. Used in a mass they are as handsome as a bed of geraniums. Pkt. 100 seeds, כૅc.

\section{LADY ROOSEVELT ASTER}

This is an exceedingly mammoth Aster and is a rampant grower, producing immense flowers, 5 to 6 inches in diameter. The long, broad petals are curled, giving an appearance of a graceful chrysanthemum; color a deep rose-pink. Packet, 75 seeds, 5c.

\section{ASTER LEAFLET}

My "Aster Leaflet," with full instructions, is free with an order for Aster seed of $10 \mathrm{c}$ or over.

\section{CRIMSON GIANT ASTER}

One of Dreer's Asters, dark blood crimson, of remarkable perfection of form and appearance, the flowers frequently measuring 5 inches across. Packet, 75 seeds, 8c. 
KIXG NEEDLED TIPE ASTERS A distinct class, the long, narrow petals having somewhat the appearance of being quilled. Price for pkt., finest mixed, 75 seeds, 5c.

\section{ENCHANTRESS ASTER}

A splendid Aster introduced by Tick, highly recommended for commercial growing. The plants are upright in habit, bearing immensely large flowers on long, strong stems The color is soft pink, like that of the popular Pink Enchantress Carnation. The blooming period is an adrantage, too, as they come between the mid-season and the lateblooming sorts. Pht., 75 seeds, Sc.

\section{PEERLESS PIXK ASTER}

Introduced by Dreer, and said by experts to be the best shell-pink of its type. It is a cross between the pink Crego and late-branching shellpink, but is more closely related to the latter class in form, color and season of flowering. They bear immense flowers, 4 and 5 inches across, of a beautiful rose or shell-pink color. Packet, 60 seeds, Sc.

\section{AIERICIX BEILTY}

Similar in type and growth to the Late Branching Asters, large, full flowers with incurase petals and stout stems from 15 to 24 inches in length and longer flowering than any other Aster. Should be planted early to give it a longer season of growth and it will continue blooming until killed by the frost. Especially desirable for cut flowers and recommended for florists' use.

American Beauty Rose, pht., 10c.

American Beauts Lavender, pkt., 15̃.

Imerican Beauty Purple, plit., 10c

Imerican Beanty September Pink, plit., 1 15c.

Collection Yo. 003 -One packet each, four colors American Beauty Aster, 40 .

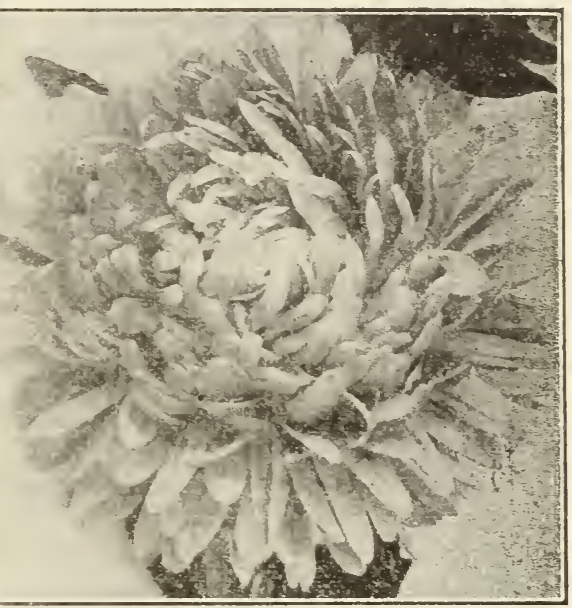

Enchantress-Branching Type

HEARTS OF FRANCE

Claimed to be the best red Aster ever introduced. Opens red and retains its remarkable beauty to the very end. Plants large and robust, branching type, long stems with few laterals. Flowers large and full, with never a trace of hollow center. Mid-season. Price, packet, 15c.

coleil DOr, Golden sun. The flowers ¿re of good size, borne on long, strong stems; color, pleasing light yellow. Packet, 10e.

\section{ATE A.EIICAN BR.A NCHING}

This magnificent Aster, an improved strain of Semple's Branching, produces large double flowers borne on long, stiff stems and prized by florists for cut fowers. Excellent bedder. Use With Queen of the Market and Comet types and have a succession of beautiful Asters from inid-summer to first frost. Price, packet, 150 seeds, Sc; 3 for 20e; 14 oz., 50c.

shell Pink

Lavender

White Rose or Lavender Pink

Collection No. 205-One pachet each of above separate colors, $\mathbf{4 0}$.

\section{GIANT CREGO ASTER}

Pronounced by many the best Comet, or Ostrich Plume strain. The blossoms measure 4 to 5 inches, their graceful Chrysanthemum effect being heightened by the much twisted petals. Price, packet, 100 seeds, כe.
Lavender White
Rose Pink
Rose
Mixed 


\section{GIANT BRANCHING COMET}

This Giant Branching class is an improvement on the old and inferior Comet class, not only in bearing much larger flowers, but the petals are broader and longer. Packet, 150 seeds, Se; 4 for 30e.

\begin{tabular}{|c|c|c|}
\hline White & Rose & Light Blue \\
\hline $\begin{array}{l}\text { Lavender } \\
\text { Royal Purl }\end{array}$ & & $\begin{array}{l}\text { Crimson } \\
\text { d, All Colors }\end{array}$ \\
\hline
\end{tabular}

\section{A S T E R M I X T U R E S EXHIBITION ASTER MIXTURES}

Color Mixtures. The increasing demand for Asters as cut-flowers makes it desirable to grow them in separate colors. I therefore offer my newest and largest sorts, those especially adapted for exhibition purposes, in five groups, as follows. Read and tell me if this is not a method you have long wished for.

Price, per packet, 75 seeds, 5c.

Exhibition Dark Blue and Purple Asters. A mixture including these shades in the Comet, Crego, Invincible, Queen of the Market and Semple's and Royal and Upright classès, 7 sorts.

Exhibition Deep Pink and Rose Asters. A mixture of these shades in the following classes: Comet, Crego, Crimson Giant, Invincible, King, Royal, Upright and Semple's; also Lady Roosevelt, 9 sorts.

Exhibition Lavender Asters. A mixture including lavender shades in the Comet, Crego, Invincible, Queen of the Market, Royal and Semple's classes; also Vick's Lavender Gem, 7 sorts.

Exhibition Light Pink Asters. A mixture of light pink, including all the light pink shades listed under Comet, Crego, Daybreak, Invincible, Peerless Pink, Rochester, Queen of the Market, Upright and Semple's classes, 9 sorts.

Exhibition White Asters. A mixture including Comet, Crego, Invincible, Rochester, Purity, Queen of the Market, Upright and Semple's, 8 sorts.

\section{SPECIAL EXHIBITION PRIZE ASTERS, MIXED}

This is a special mixture which we make ourselves, including large-flowering varieties only, in an attractive range of colors, especially designed for those who are growing for exhibition or commercial purposes, and we do not hesitate to class it with the best on the marliet. We have hundreds of letters commending our Asters, and know that no other general mixture will give better satisfaction. Packet, 75 seeds, 5c; $1 / 8$ Oz., 40c.

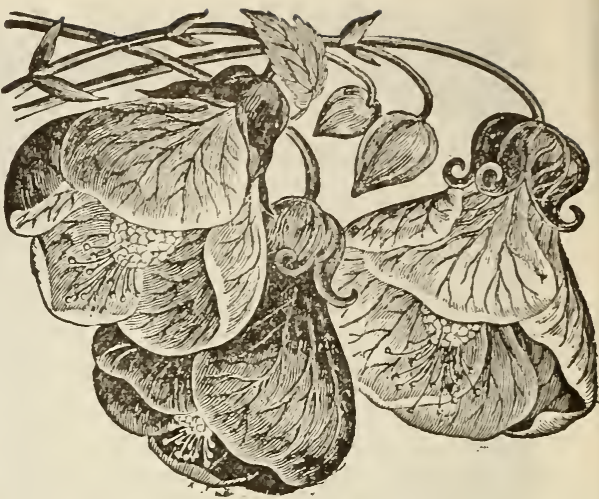

NEW HYBRID ABUTILON

Or Flowering Maple. A choice selection from newest hybrid varieties, in pure white, straw, yellow, rose, crimson and scarlet shades, with beautiful veins and markings. They bloom soon from seed and often give new and charming kinds. 3 feet. Mixed. Packet, 30 seeds, 10e.

\section{A BRONIA UMBELLATA}

The Sand Verbena, for beds, rockwork or hanging baskets. Fragrant, rosylilac flowers. Packet, 50 seeds, 5c.

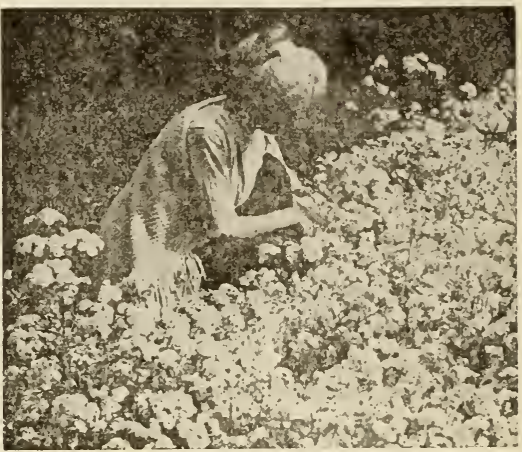

ACHILLA, "The Pearl"

A popular perennial, bearing large clusters of pure white double flowers. It blossoms all summer and is invaluable for floral pieces or bouquets, and is grand for cemetery planting, as it is perfectly hardy and takes care of itself. $1 \frac{1}{2}$ feet. Packet, 60 seeds, $6 c$, 


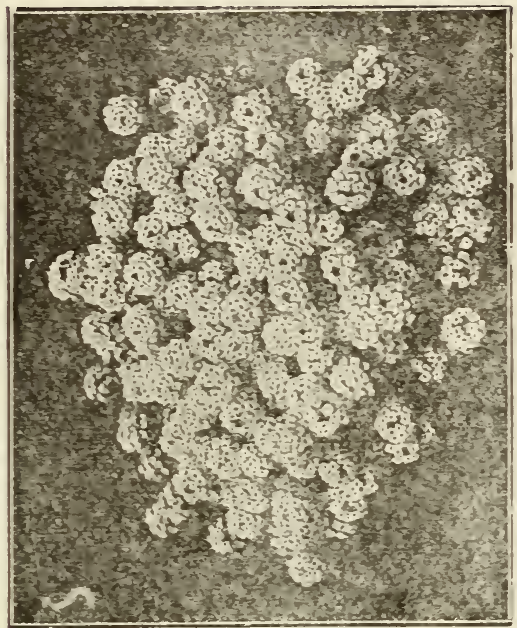

SWEET ALYSSUM

Price, each, per packet, כ̌c.

Alysium, sweet white. The common Sweet Alyssum, best for cutting. Packet, 400 seeds. 1/4 oz, 15e.

Myssum, "Carpet of sinow." A new dwarf Alyssum, growing only 2 or 3 inches high, and flowering so profusely as to make a perfect carpet of white throughout the season. splendid for pots and edgings. Packet, 300 seeds. 1's oz., 1Je.

Alysum, Little Gen. Also a dwarf variety, splendid for cemetery planting or for $\in$ dgings. The plants are more compact and the single florets larger and more closely crowded than in the common Alyssum. Packet, 400 seeds. I's oz., 15c.

Alyssum, Lilac Queen. A pretty new dwarf variety with pale lilac flowers. Packet, 200 seeds.

\section{SWEET FERY}

A graceful plant of the Artemisia family, growing 3 to 5 feet tall, with finely cut foliage and tiny greenish flowers, prized for its aromatic qualities. The sprays afford a beautiful garnish for a bouquet. Hardy annual. Packet, 250 seeds, 5c.

\section{GER I T II}

ropular edging plant, growing readily Irom seed. It comes on rapidly sown out doors in May and flowers profusely until frost. Tender perennial, 9 inches.

Blue lerfection. A splendid new sort, color darkest of all, a deep amethyst blue. Of dwarf, compact habit. Packet, se.

\section{AMIRINTHLS}

A mixture of named varieties, all the best sorts. Splendid where tall effects are desired. 3 to 4 feet. Packet, 300 seeds, je.

Asparawus Sprengeri. Nothing is handsomer for hanging baskets, bouquets, wreaths or other decorating. Its drooping. featherr sprays grow from two to eight feet long, and multiply so rapidly as to give an abundance of green for cutting. Packet, 12 seeds, sc.

Asparagus Plumosus. The Asparagus Fern, with foliage more graceful and lace-like than the most delicate fern. Nothing is finer for cutting and the sprays will last for weeks. One of the best of house plants, succeeding almost anywhere. Packet, 7 seeds, Sc.

Asparagus Mixed. \& seeds of each, Sc.

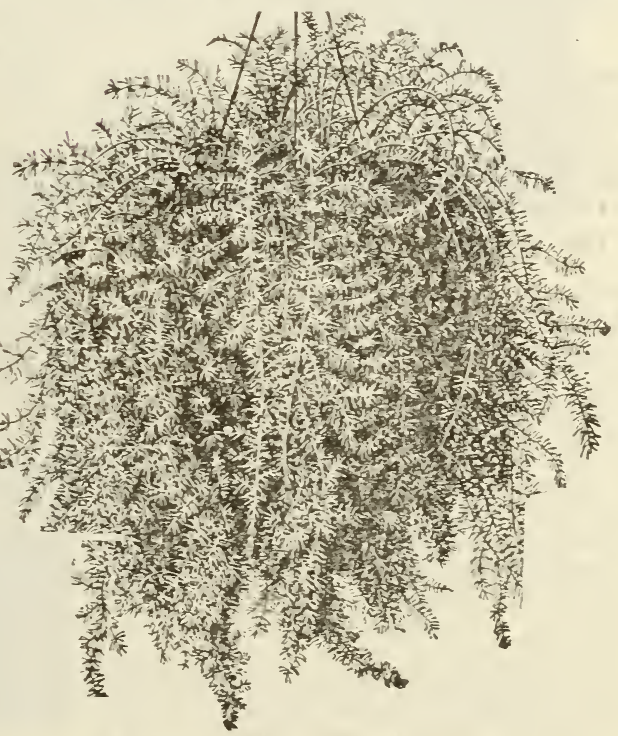

ASPARAGUS SPRENGERI 


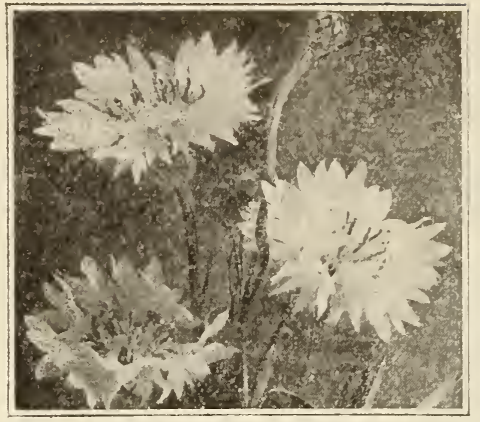

BACHELOR'S BUTTON (Centaurea Cyanus)

Also known as "Corn Flower," "Blue Bottle" and "Ragged Sailor." The blues, with such yellow flowers as the California Poppy, Calendula or other Marigolds, make a striking combination. $11 / 2$ feet. Price, packet, Јc.

Double Blue. Deep blue, semi-double flowers, one of the best blues for cutting. Packet, 25 seeds.

Double Rose-Pink. Packet, 25 seeds. Special Mixed. A fine assortment in many shades, double and single. Packet, 40 seeds.

\section{DOURLE BALSAIS}

Prize Mixed. My special mixture of choice named varieties, including also prize strains of various growers. Unchallenged for beauty and variety of colors, including lovely solid shades and beautiful spotted or camellia-flowered Balsams. Packet, 30 seeds, 5c.

\section{ORNAMENTAL BEDDING PIANTS}

\section{Rivals of the Coleus}

Price, each, per packet, 125 sends, Gc; ł oz., 15e; one packet of eacñyc.

Chilean, or Brazilian Bect. Leaves are crinkled and all shades of crimson, rose and yellow.

Crimson, or Willow-leaved Bect. With narrow drooping foliage of fine deep glossy crimson, this equals the Coleus as an ornamental bedder, either used alone or with some contrasting leaf or color, such as Dusty Miller, Golden Feather, Feverfew, Sweet Alyssum, Candytuft, or Mignonette.

Coleus-leaved Borecole. A new form of variegated Kale, very useful and quaint for garnishing and splendid for bedding, especially where a late display is desired, as it stands almost zero weather. The finely cut and curled leaves take on, at approach of autumn, many striking colors, shades of rose and pink, violet, green, white, yellow and purple.
HEGONIA

Price, packet, 10c.

Prize Hegonia. Saved from the newest and best varieties, including the bronzy-leaved sorts, with flowers of very hue and shape. They grow easily from seed, bloom early and continously and are most brilliant plants for potting or bedding.

\section{RIRD OF PARADISE \\ (Poinciana Gillesi)}

$\Delta n$ attractive plant, producing in large compact trusses, orange-red flowers, with long red stamens; the foliage also is decorative, similar to the Acacia. Greenhouse perennial except in the south, where it is hardy. Packet, 12 seeds, 5c.

\section{CALLIOPSIS}

Dwarf Callionsis, Beanty. A gem for pots, bearing a mass of golden yellow flowers, with dark crimson centers. Packet, 150 seeds, śc.

Dwarf Calliopsis, Mixed. Splendid sorts, including crimson and gold "Beauty" (see cut), and other hybrids in great variety. Plants 6 to 8 inches, splendid for edging. Packet, 200 seeds, for 5c.

Calliopsis, Special Tall Mixed. Both single and double sorts, including the usual bronze-red and gold shades. If not allowed to seed, they will bloom the entire season. 18 inches. Packet, 300 seeds, 5̃c.

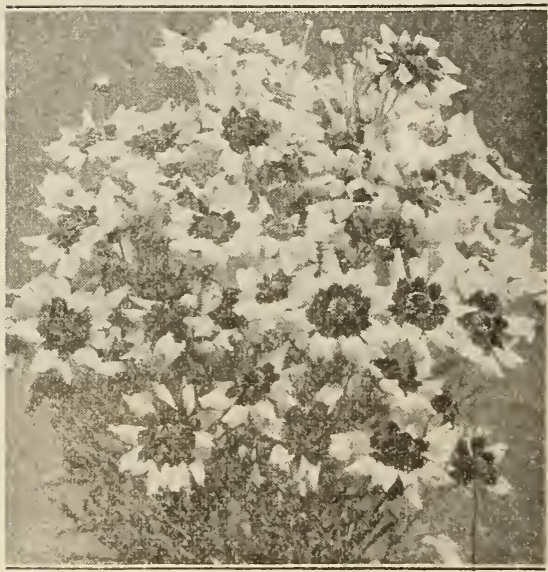

Dwarf Calleopsis Beauty 


\section{CALCEOLARIA GRANDIFLOR.I}

These are gorgeous plants for the greenhouse or window, remarkable for their orchid-like blossoms. They come into flower eight months after sowing, bearing hundreds of curious pocketlike flowers, spotted and blotched and margined in a most unique fashion, in such shades as rellow, maroon, crimson, white, etc. Greenhouse biennials. Packet, 125 seeds. 10c.

\section{CILETDLLI OR POT MARIGOLD}

Fine annuals for cutting. They bloom early and long, especially in the cool fall days after most anmuals have gone to seed. The place of slort-lived plants may be filled by scattering seeds of Calendulas in May or June. They come in every shade of yellow or deep. golden, double and semi-double. Mixed. Packet, 100 seeds. ic: $1 / 4$ oz., 15c.

\section{CIVIA}

Price per packet, $\epsilon a c h, 12$ seeds, 5c.

Bronze-Leaved Canna. A mixture of dark or red-leased, dwarf varieties, splendid where foliage effect is desired.

Canna, Prize Hixed. A splendid strain of the new Dwarf Crozy type, saved from the newest and best named varieties; especially recommended for its large, gladiolus-like blooms, and beautiful colors. Cannas are easily raised from seed and bloom the first season. Oz., 25e.

Giant Canna, Mixed. Tall-growing varieties, including both bronze and green-leaved sorts. Oz., 2ü.

\section{L.I FRANCR CANNA}

A lovely new Canna. Plants very compact, with enormous trusses standing well above the foliage, a beautiful pink in color like that of the popular La France Pose. $3 \frac{1}{2}$ feet. Packet, 6 seeds, -ic.

\section{GI.ITT CEYTALIEA or Srreet Sultan}

This is the Centaurea Imperialis, or Giant Sweet Sultan, a new strain of the beautiful Centaureas which you should not fail to try. They are of easy cultivation, and are equally beautiful for the garden or cut flower use. White, lilac, yellow and rose shades mixed. $11 \frac{1}{2}$ feet. Packet, 50 seeds, je.

\section{CINARY BIRD FLOWER}

A splendid climber for the porch or trellis. It grows rapidly, has very pretty foliage, and curiously shaped, canary yellow flowers with fancied likeness to a bird with outstretched wings. I recommend it as one of the most desirable vines to be obtained from seed. Annual. Pkt., 20 seeds, 6c.

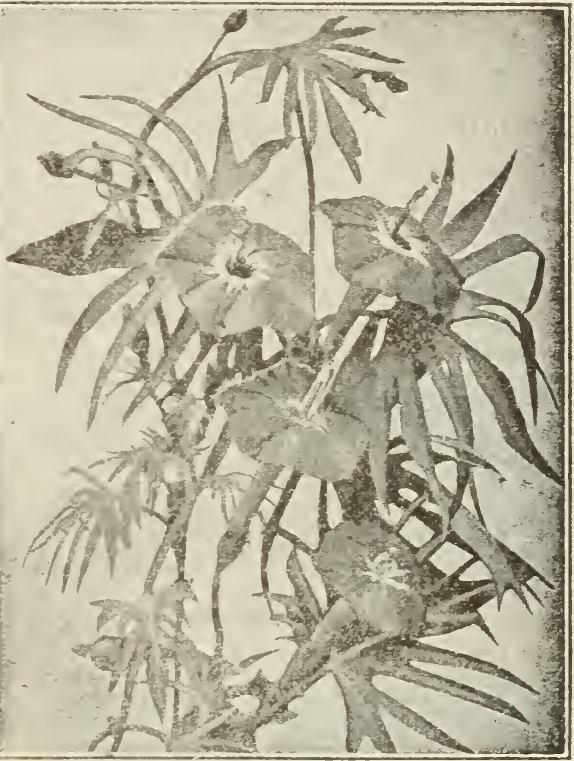

\section{THE CARDINAL CLIMBER}

\section{A Splendid New Climber}

The vine quickly reaches a height of 30 feet or more. The blossoms are about $1 \frac{1}{2}$ inches in diameter, in clusters of 5 to 7 blooms each, and as the name indicates, are of a rich cardinal red. It likes sun and good soil. If started in the open, do not sow until settled warm weather, as the seed will rot in cold, wet ground. File each seed, or slightly cut through the outer covering, soak in luke-warm water over night, and sow in a warm place. Packet, 10 seeds, Se; 2 packets, 15c.

\section{CLIRKIA ELEGANS}

A pretty, desirable annual with racemes of white or varying shades of red. Popular in European gardens, but not so well known here. Double mixed.

1 foot. Packet, 400 seeds, 5c. 


\section{CANDYTUFT}

Price, each, per pkt., 5́c; any 3 pkts., 12c. Giant Hyacinth. Listed also as Rocket and Empress. Each plant has from four to nine branches, crowned with a bunch of magnificent white flower spikes, sometimes 6 inches long. Annual, 8 inches. Packet, 200 seeds, $1 / 8$ oz., 15e.

Rose Cardinal and other beautiful crimson shades. Packet, 100 seeds.

Special Mixed. A mixture of Giant Hyacinth and colored varieties. Packet, 150 seeds, 1/4 oz., 15e.

\section{CHRYSANTHEMUM}

Price, each, per pkt., 5c; any 3 pkts., 12c. Bridal Robe. A hardy biennial, blooming the first year if started early. It has fern-like foliage and is covered for a long period with hundreds of graceful white flowers, both double and semi-double. Splendid for home or church decoration. 1 to 2 feet. Packet, 75 seeds.

New Dwarf Double. Dwarf and compact plants, densely covered with small flowers, in white, cream or gold. Best annual sort. Packet, 75 seeds.

Northern Star. White, with yellow center, dark disc, flowers extra large and showy (see cut). Pacliet, 50 seeds.

Special Mixed. Including the above three and other double annual varieties, also the Single Annual Sorts, known as "Painted Ladies." Packet, 150 seeds.

Japanese. Saved from an extra choice collection of house Chrysanthemums. Beautiful new and often valuable varieties are obtained from seed. Packet, 75 seeds, each, 10c.

\section{COBEA SCANDENS}

Blue Cobea. A beautiful climber for either outside or for the window garden. It grows 20 to 30 feet, branching freely, and being a rapid climber, is especially fine for northern regions. The large bell-shaped flowers open a clear green but soon turn to a lovely lilac blue. Price, packet, 12 seeds, こ̌; $1 / 4$ Oz., 15c.

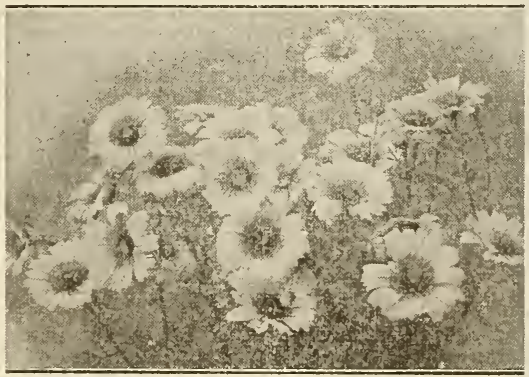

Chrysanthemum, "Northern Star"

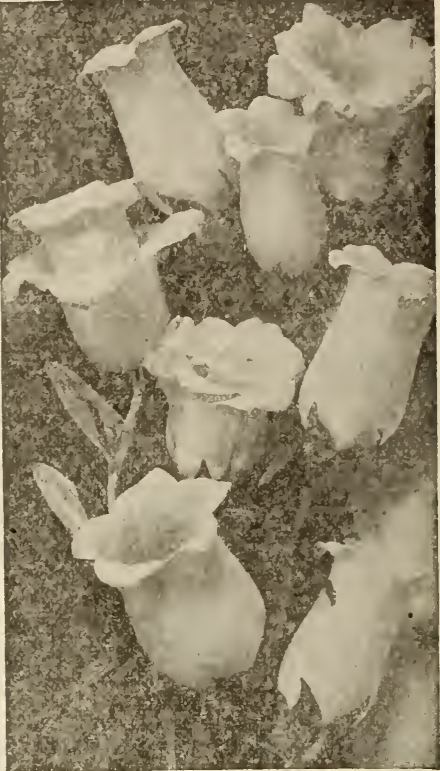

CANTERBURY BELLS

Much attention is now paid to this stately, old-fashioned flower. Easily grown from seed and fine for the Perennial Border. Hardy biennial. $21 / 2$ to 3 feet. Price, packet, 400 seeds, 5c. "Cup and Saucer." A showy strain, with flowers resembling a cup and saucer. A single plant bears from 100 to 200 blossoms. Mixed.

Double vixed. With bells doubled or trebled.

Pink Shades. Choice pink shades.

Single Mixed. A splendid prize strain. Special Mixed. My above four strains mixed, nothing finer, is oz., 15c.

\section{CYPRESS VINE}

A beautiful climber, always a favorite, with delicate, feathery, dark green foliage, bearing bright, velvety, starshaped flowers in scarlet and white. Mixed. Packet of 30 seeds, 5e; 1/4 oz., 15c.

\section{DATURA (Trumpet Flower)}

Also called "Sweet Nightingale." A bushy plant bearing immense funnelshaped blossoms, in white, lilac and yellow, delicately scented, there being as many as 200 blossoms on a single plant in a season. Double and single mixed. 2 to 4 feet. Pkt., 60 seeds, 5c. 


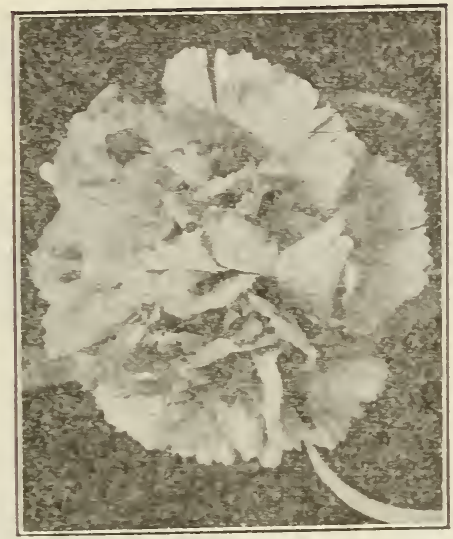

CARYATION

Beautiful rarieties of Carnations may be raised from seed. They bloom in from three to four months from seed sown in the open ground, and fully $\delta 0$ per cent come double. Hardy in all sections but the extreme north.

Giant Marguerite Carnation, Mixed. The flowers are of unusual size and brilliant colors, very double and beautifully fringed, and include the new yellow, also innumerable shades of scarlet, crimson, pink, striped, flaked white and pure white. Packet, 100 seeds, Se.

Chaband's Everblooming Carnations. A new strain of Hardy Carnations, developed by a French specialist, blooming almost as soon as the Marguerite and flowering indefinitely. Mixed, in choicest colors. Packet, 70 seeds. Sc. Carnation, Special Ilixed. A mixture of all varieties. Packet, 50 seeds, 5c.

\section{CASTOR BEAN (Rieinus)}

Price, packet, 12 seeds, 5c; oz., 15c. Aside from their use in decorative beds Castor Beans are recommended as affording a quick shade for poultry yards. 10 to 12 feet.

Green-Leaved. Immense plants with gigantic green leares. $1 \frac{1 / 2}{2}$ to 2 feet across.

Red-Leared. Both stems and leaves are highly ornamental, the latter being a shiny, bronzy-red. This is a mixture of three best red or bronze-leaved sorts: Cambodgensis, large palm-like leaves; Panormitanus, huge leaves of a peculiar bronze shade, and Sanguineus, or Mexican, in which stems and leaves are red.
Special Mixed. All the above mixed, including also the well-known Zanzibarersis.

\section{COLEUS}

A splendid assortment of highly colored varieties, including handsomely crinkled and large heart-shaped leaves in many pleasing and surprising combinations of color. Packet, 100 seeds, 10c.

\section{Cockscomb (Celosia) \\ Price, each, per packet, sc.}

Chinese wool Flower. A new and unique Feathered Cockscomb. It grows 2 to 3 feet high, each 'branch covered with a great head of rich crimson flowers having the appearance of soft, silky wool. Tery effective in beds and borders, splendid for cutting as it lasts many days, and dried it is a valuable addition to the winter bouquet. It blooms continuously until cut off by frosts. A much longer blooming period is obtained by starting seed indoors. Do not sow outside until settled warm weather. Packet, 40 seeds.

Improved Ostrich Plume Cockscomb. A superb strain saved from a magnificent collection of exhibition varieties. With its graceful feathery plumes of brilliant crimson and other magnificent shades of red and gold, it makes a great show for the garden, lasting until everything else is gone. 18 to 24 inches. Mixed. Packet, 100 seeds.

Cockscomb, special Mixed. Splendid mixture, including Wool Flower, Plumed and Combed varieties. Packet, 150 seeds.

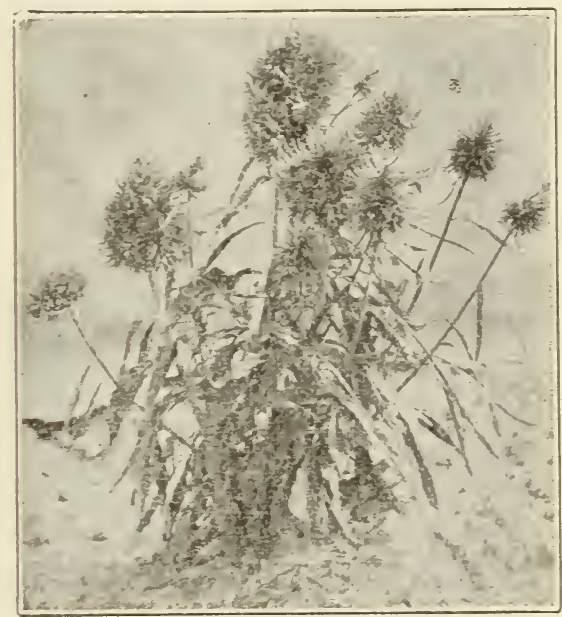

Chinese Woolflower 


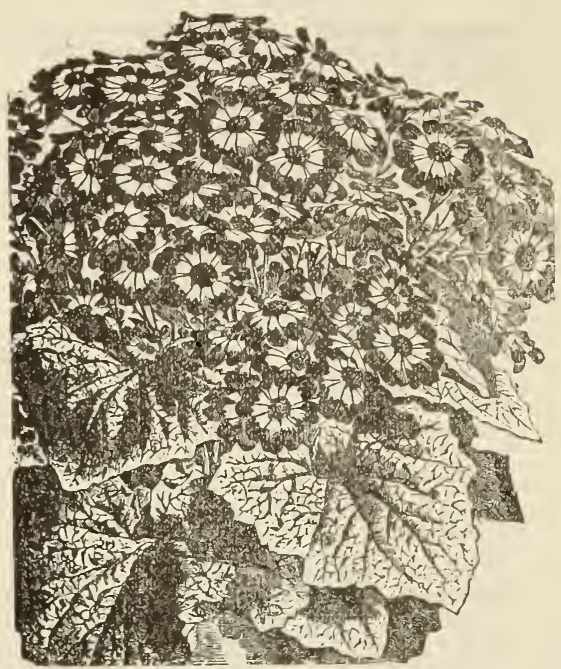

GRANDIFLORA CINERARIA

A beautiful greenhouse ilant, very easily raised from seed, affording a mass of gorgeous blooms in the late winter and spring. My mixture is grown from two extra choice prize exhibition strains from new varieties of the large-flowering $d w a r f$ and grandiflora sorts, whose large blossoms cover the plants with most brilliant hues in crimson, magenta, violet, purple or variegated shades. Mixed. Packet, 100 seeds, 10c.

\section{COIX LACHRYMAT (Job's Tears)}

Plants with corn-like leaves, suitable for the Perennial Border, but quite as often grown for the hard, shiny seeds so largely used in basket and raffia work, or for portieres or necklaces. The teething baby especially will much appreciate one of these hard necklaces. For sowing, file the seeds and sorv in a warm place. 2 to 3 feet.

Job's Pearly Tears. Light, or pearlcolored seeds, very handsome for stringing. Packet, 25 seeds, ne; oz., I5e; $1 / 4$ lb., 40e.

Gray Job's Tears. The dark-seeded sorts, also in much demand. Packet, 30 seeds, se; oz, 10e; $1 / \frac{1}{4}$ lb., 25 s.

\section{Cosmos}

For fall blooming Cosmos has no superior, both flowers and foliage being unsurpassed for decoration. Late sorts are not adapted, however, to the extreme north, seldom blooming before frosts.

EXTRA EARLY, Mammoth Flowering. Our grower says: "The blossoms, under ordinary field cultivation, average 4 to 5 inches across, surpassing in size any of the late varieties. From seed sown in the open ground, the 'white' blossoins in exactly 60 days, 'pink' in 65 days, "crimson' in 70 days." Packet, 8e; 3 for 20e; $1 / 4$ oz., 30c.

White Pink Crimson Mixed Lady Lenox. New varieties of gigantic size and beauty. Mixed. Pacliet, sc.

Warly Mammoth Flowering. Regular strain not so early as the Extra Early. Packet, 5e; 3 for 12c.

White Pink

Crimson

\section{NEW CRESTED COSMOS}

Price, packet, 25 seeds, 8c; 3 for 20 . A new late double Cosmos of striking colors and form. Like many double flowers from seed, they do not all come true, but will yield a large percentage of doubles, as shown in the cut.

Crimson King. Beautiful dark crimson. Pink Beauty. Soft, delicate pink.

white Queen. The same charming double form in white.

\section{COSMOS, SPECIAL MIXED}

This mixture includes all the kinds described on this page, and other fancy varieties. Pkt., 50 seeds, 5c.

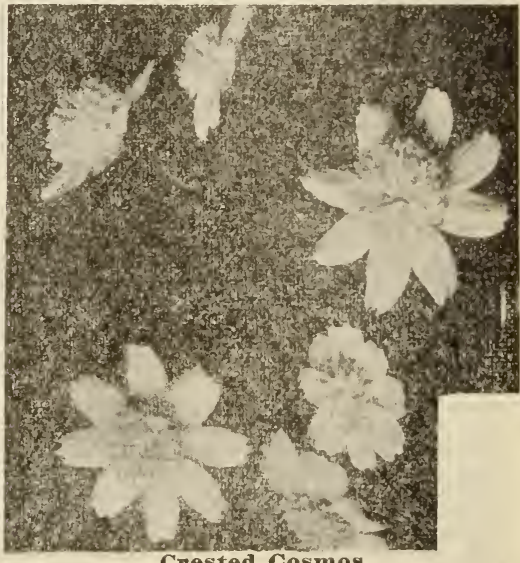




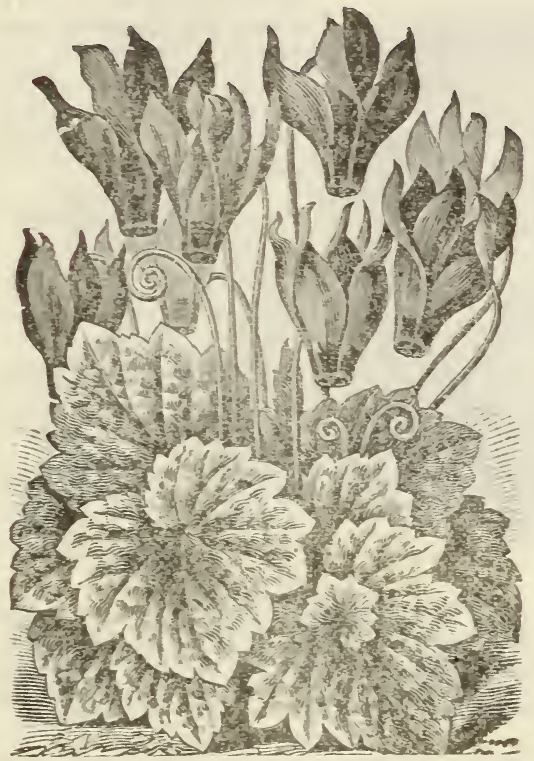

CICLA.YEN

Charming window plants, with ornamental foliage and richly colored orchid-like flowers in pink, white and crimson shades. They are easy to raise from seed, scarcely a seed failing to germinate.

Cyclamen Giganteum. A splendid large-flowering strain, mixed in all the Cyclamen colors. Packet, 12 seeds, 10c. Butterfy Cyclamen. A new type of surpassing beauty in which the edges are deeply waved or crinkled. Packet, 10 seeds, 15 c.

\section{COLUMBINE (Aquilegia)}

Popular hardy perennials producing graceful spurred flowers on stems 2 feet or more above the beautiful dark green foliage. Easily grown from the seed. Price, packet, 10c.

Chrysantha. Long spurred golden yel$10 \mathrm{w}$.

Chrysantha Alba. Large pure white.

Coerulia, Hybrids (Rocky Mountain Columbine). Blue and pink mixed with yellow.

Jaetschani. Yellow with red tip.

skinneri. Large scarlet, extra fine.

Collection-One full packet each of 5 colors, 40c.

Long Spurred Columbines. Mixed splendid large flowering, long spurred varieties. If not allowed to seed these sorts will bloom through a good part of the summer. Packet, 10c; 1/8 oz., 10c. special Mixed. Including the above and many other beautiful hybrids. Double and single. Pkt., 200 seeds, 5c.

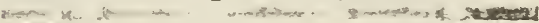
BUTTERFLY FLOWER

New Hybrids, Mixed. Large flowering varieties of these dainty, orchid-like flowers, curiously marked with crimson, lilac, purple and yellow blotches. Immense bloomers and easy to grow. Pretty to edge beds or decorate bouquets of coarser flowers. Sow some seed in August for the house. Plants will bloom all winter. Annual. 1 foot. Packet, 200 seeds, 5c.

\section{DAHLIA.}

Dahlias are as eásily raised from seed as sun-flowers, and one often gets unique and beautiful sorts in this way. They bloom the first year, beginning in midsummer, and continue until the frost comes. Not all come double. Price, each, per packet, 20 seeds, 5c.

Double Dahlias. Best mixed. A splendid strain saved from the best and latest varieties. Packet, 20 seeds.

Double Cactus Dahlias. Flowers are less regular and formal, giving added grace and charm.

Single Prize Dahlias.. A beautiful strain, including the popular "Century," or pink and white variety. Highly prized for decorating. Packet, 30 seeds.

Dahlia, Special Mixed. The above four strains mixed.

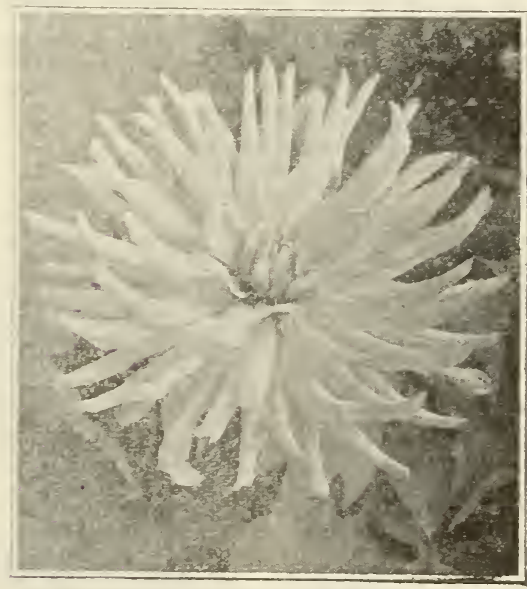

Cactus Dahlia 


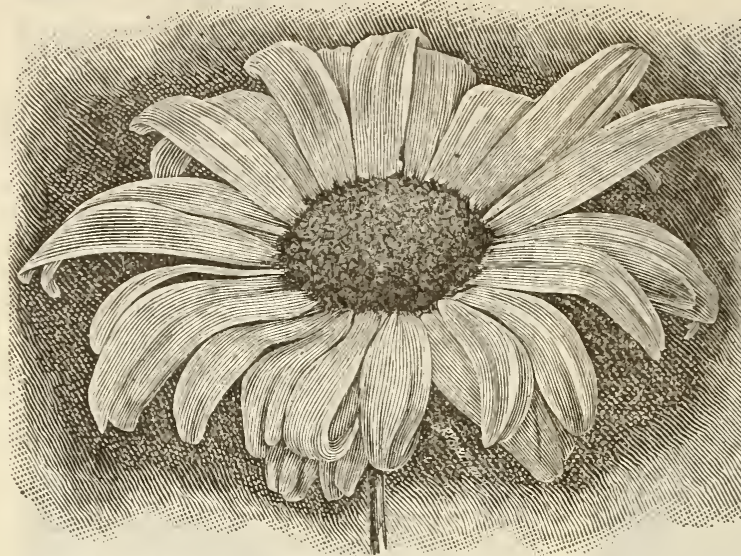

MARGUERITE DAISY Yellow Marguerite (Anthemis Kelwayi). A hardy perennial, bearing all summer daisylike golden-yellow blossoms, excellent for cutting, 18 to 24 inches. Packet, 5e.

\section{SWAN RIVER DAISY (Brachycome)}

Charming little plants with feathery foliage and pretty cineraria or star-like flowers.

Little Blue Star. An improved new variety with multitudes of blue starlike flowers. Packet, 200 seeds, 8c.

Swan River Daisy, Mixed. The same charming flowers in pink, blue or white, mixed. Packet, 300 seeds, 5c.

SHASTA DAISY, ALASTEA

One of Luther Burbank's many important contributions to the floral world. It is perennial and absolutely hardy, and blooms somewhat the first year from seed. The flowers are white with yellow center, extremely large and graceful, freely produced on long, stiff stems. Alaska is the largest and best variety. 2 feet. Pkt., 35 seeds, 6c. ENGLISH DAISIES (Bellis Perennis) No flower has more often been the theme of the poet than the dainty English Daisy. They bloom the first year; with protection the plants live over winter, their blossoms being the first to greet one in the spring. Price, each, per packet, 125 seeds, 5c.

Longfellow Daisy. The "wee modest, crimson-tipped flower," remarkable for the size and doubleness of its dainty rosy blossoms.

Snowball Daisy. An extra large, very double, pure white Daisy.

Snowball Daisy, Mixed. A splendid mixture of English Daisies, including the Snowball and Longfellow and the newer hybrids.

\section{AFIRICAN DAISY}

Price, each, per packet, 5e; the 2 for 8 e. African Orange Hybrids (Dimorphotheca Aurantiaca). The plants are low growing, covered with Margueritelike flowers in shades of yellow from golden to sulphur, deep orange and salmon. Many are ringed and zoned. Easily grown from seed. Do best in a dry sunny position. 10 inches.

African Lilac Daisy (Arctotis Grandis) A handsome annual with whitish leaves and myriads of showy flowers, nearly as large as the Shastas. The upper sides of the petals are white, the under sides lilac. Of easy culture, blooming throughout the season. $2 \mathrm{ft}$.
DUSTY MILLER

Valuable foliage plants, used to mass with dark-leaved plants or for edging beds. A fine mixture of Centaurea Gymnocarpa and Cineraria Maritima some are hardy perennials. 1 foot. Packet, 300 seeds, 8c. $1 / 8$ oz., 20c.

\section{FLAX (Linum)}

Perennial Flax, Mixed. Blue or white flowers, borne in great profusion with charming. Vary hardy. Mixed blue an airy grace, both beautiful and charming. Very hardy. Mixed blue and white. Packet, 100 seeds, 5c.

Scarlet Flax. Pretty scarlet flowers similar to the perennial blooms, but the plant is annual. Packet, 200 seeds, sc; one packet of each. 8c.

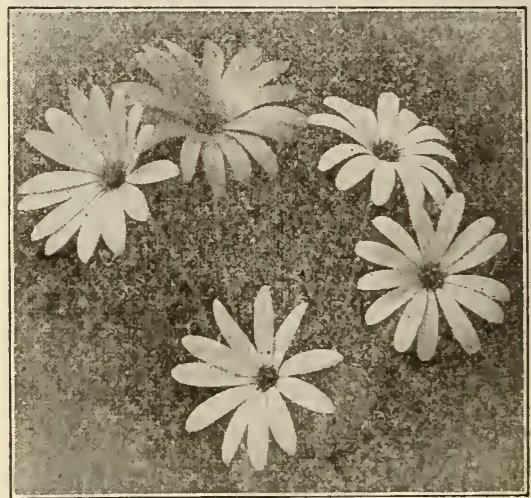

African Orange Daisy 


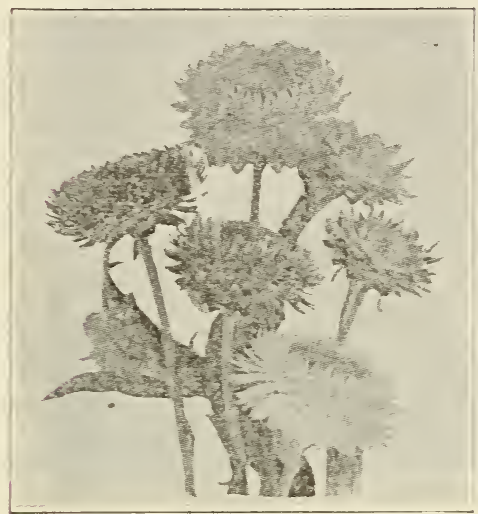

Helichrysum or Straw Flower

\section{EVERLASTINGS}

Everlasting flowers, when wanted for winter bouquets, should be picked before fully open, and hung head downward to dry. Price, each, packet, 5c; any 3 packets, 12c.

Acroclinium Roseum. One of the most beautiful Everlastings. Flowers are double, a delicate rose pink with golden center. Packet, 75 seeds.

Globe Amaranth. The plants bear great quantities of clover-like blossoms. Attractive in bud and flower. Mixed. Packet, 75 seeds.

Helichrysum Monstrosum. Straw Flower. The blossoms are large and extra double in many shades of yellow and scarlet, about as showy as Asters. Mixed. Packet, 150 seeds.

Rhodanthe. Flowers are deep blood red, rose and yellow shades, with dark eyes. Mixed. Packet, 125 seeds.

Statice Latifolia, or Sea Lavender. Large clusters of delicate pale lavender flowers, splendid for garnishing a bouquet of coarser flowers. Fine also dried for the winter bouquet.

Xeranthemum. Beautiful violet and rose-colored flowers. Both buds and flowers are handsome to save. Packet, 150 seeds.

Yixed Everlastings. A mixture of the above named varieties, affording a splendid assortment. Large pkt., Jc.

Collection of Everlastings, No. 107.

full packet of each of 6 varieties, 22c.
Feverfew (Matricaria)

Price, each, per packet, 5c.

Dwarf Snowball. Charming little plants, oval in shape, covered with clusters of pure white double flowers; very desirable for bedding or for edgings. $S$ inches. Packet, 200 seeds.

Dwarf Golden Ball. A fine display is made by combining the white and the golden. Both are hardy perennials, blooming the first season. Packet, 200 seeds.

Golden Feather (Parthenifolium Aureum). Low growing, with golden variegated foliage, used for edgings. Packet, 500 seeds. 1-16 oz., 10c.

Tall snowball. One of the prettiest things I have ever seen was a single specimen of this tall Feverfew, 3 feet tall, in bush form, which was covered for weeks with a mass of double white blossoms. Hardy perennial. Packet, 300 seeds.

\section{ESCISCHOLTZIA OR CALIFORNIA POPPY}

Price, each, per pkt., 5c.

Bush Eschscholtzia. Low shrubby plants, with flowers daintily crinkled and extra large, on long, stiff stems. The most beautiful thing in yellow for cut flowers. Packet, 75 seeds.

Burbank's New Crimson. The most beautiful of the new Crimson-flowered type. Packet, 150 seeds.

"Golden West." The California state flower, dotting her meadows and making them gay with brilliant yellow. Packet, 200 seeds.

Vesuvius. A beautiful dark reddish, maroon, an entirely new shade in California Poppies. Packet, 100 seeds.

White. Large pure white.

Rosea. Fluted flowers, bright rosy pink.

Eschscholtzia, Mixed. The above varieties and other shades of yellow, white and rose. Packet, 200 seeds.
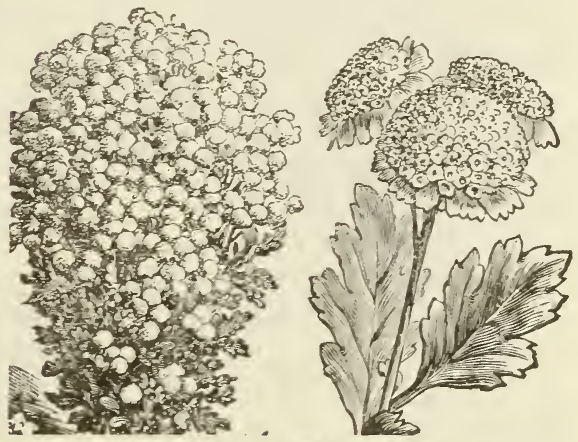

Feverfew (Matricaria) 


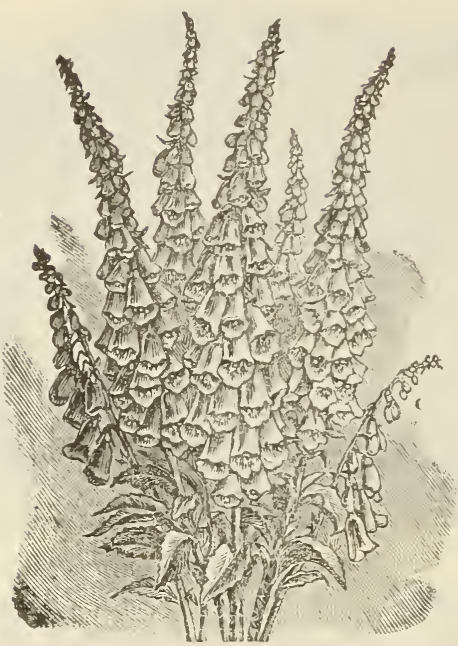

FOXGLOVE OR DIGITALIS

The Foxglove become more popular each year. It is perennial and perfectly hardy, very easily grown from seed and is fine for shrubberies and other partially shaded places. It sends up stately stalks 2 to 5 feet high, covered with thimble-shaped flowers in varied and beautiful colors. This is a strain of Gloxeniae-flora, which rivals the gloxinia in odd and varied shadings and markings. Splendid mixed. 3 to 5 feet. Packet, 400 seeds, 5c; 1-16 oz., 15e.

\section{FORGET-ME-NOT (Myosotis)}

To let you try some of the choicest varieties I make a mixed packet containing the most desirable sorts, such as: Alpestris, the Alpine Forget-MeNot; Indigo Blue, Victoria Dwarf, very floriferous, and others. These different sorts are in varying shades of blue, and will furnish both early and late bloomers, thus giving the longest possible flowering season, and many will bloom the first year. 6 inches. Packet, 250 seeds, 5c; 1-16 oz., 15c.

\section{FOUR O'CLOCKS}

Four O'clocks should be grown for the children if for no other purpose, from which they may pick freely, they so enjoy the bright colors and sweet odor. In a large garden they may be used effectively to border walks, or as a background for lower-growing plants. Mixed. 2 to 3 feet. Packet, 25 seeds, 5e.

\section{GAllLARDIA, PICTA}

Very showy garden annuals, 1 to 2 feet high. Grown in masses they are especially effective; large flowers, 2 to 3 inches across, produced from early summer until irost; unrivalled for cutting. Color rich shades of scarlet, red and yellow, and of the easiest culture. Single mixed seed, packet, sc.

G.IILLARDII, PICTA LORENZIANA The double form of the proceeding in rich shades of red and yellow. Double inixed seed, packet, sc.

\section{GERINIUM}

New California Geranium. Seedling Geraniums almost always give some nerv varieties, and being easy to cultivate they are interesting to grow. This mixture contains a splendid new strain of California Zonale varieties in shades of blush pink, crimson and scarlet. Packet, 40 seeds, 6c.

Lary Vashington Greraniums, or l'elargonium. Packet, 10 seeds, 15.

\section{GILIA}

Has dainty flowers in rose, blue or white, and graceful, finely cut foliage serving nicely for a decoration of green. A good honey plant. 1 foot. Packet, 400 sceds, Jc.

\section{GOURDS}

If you have an odd corner or an old brush heap, trail the gourd vine over it. Its fruit has many uses, but if for no other purpose raise it for the little ones. They much enjoy the striped and odd-shaped fruits-Calabash, Bottle, Dipper, Dish Cloth, Hercules Club, Nest Egg, Sugar Trough, and many other sorts. Mixed. Packet, 50 seeds, 5e; large packet, $1 / 2$ oz., $12 c$.

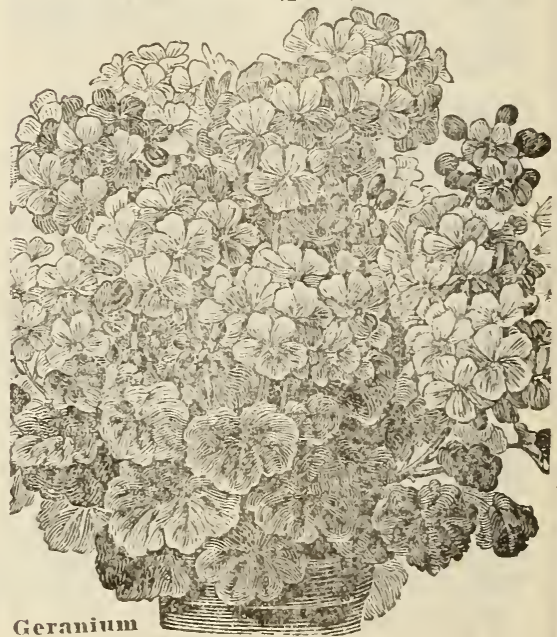




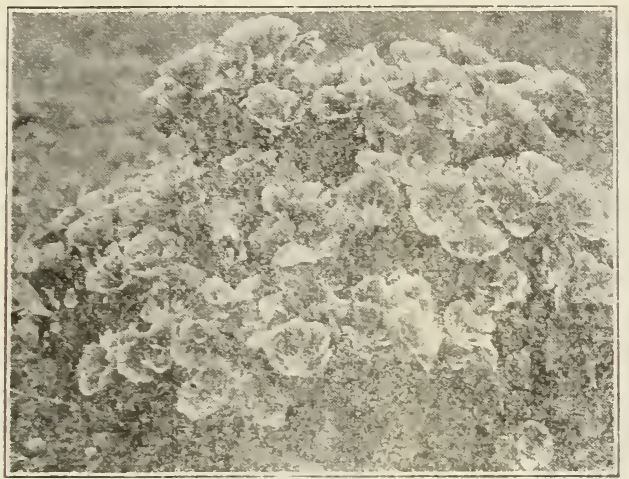

Godetia

GODETI. the "Satin Flower" Little annuals of easiest culture. The blossoms have a satiny lustre and range in color from brilliant reds, through rose to delicate pink and lavender. Fine for shady places. $\delta$ inches.

Godetia Mixed. All shades mixed. Packet, 400 seeds, 5e.

\section{GLADIOLUS}

It is interesting to see the endless rariety of colors and fantastic markings that come from the seedings and one often gets valuable new varieties. This is a mixture of 3 very choice strains. 3 feet. Packet, 65 seeds, 8c. For bulbs, see Plant Department.

\section{GLOXINIA}

Popular greenhouse and conservatory plants with gorgeous bell-shaped flowers and ornamental foliage. This is a splendid mixture including strains of new and rare French hybrids, tigered and spotted sorts, and a special giantflowering superb class, affording delicate shades and all the other brilliant Gloxinia combinations. Indeed, all the Gloxinia colors are so brilliant one seldom grows an unsatisfactory plant. II ixed. Packet, S5 seeds, 10e.

\section{ORNAMENTAL GRASSES}

For ornamenting the border, for summer cutting, and for the winter bouquet, these are indispensable. This mixture includes beautiful feather and striped grasses and many other choice varleties, some annual, others perennial. Large packet, Je.

\section{GREVIWLEA}

Or Silk Oak. A beautiful fernlike plant for the window garden coming from seed and making in two or three months a very ornamental little plant. 2 feet. Pacliet, 50 seeds, 8c.

GIPSOPHILA, "Angel's Breath" Gypophila Paniculata. Also called "Baby's Breath." It is extensively used for decorating, its mist-like sprays setting off a bouquet as dainty lace does a lady's dress. Hardy perennial. 11:2 feet. Packet, 300 seeds, 5c.

Double Grpsophila. New and very desirable. The spray is just a little heavier because of the double flowers, but loses none of its dainty or graceful effect. Hardy perennial. Facket, 50 seeds, 10c.

Gypsophila Anumal. Sow at different times througout the season, and always have a quantity to use for decorating. Pkt., 500 seeds, 5e; 1-16 oz., 12c.

\section{FREESIA}

New Mybrids. These beautiful plants, though generally grown from the bulbs, may be easily raised from seed and made to bloom within a year. The flowers are deliciously fragrant, cut well and are adapted to design work. White and mixed colors. Packet, 40 seeds, 10c.

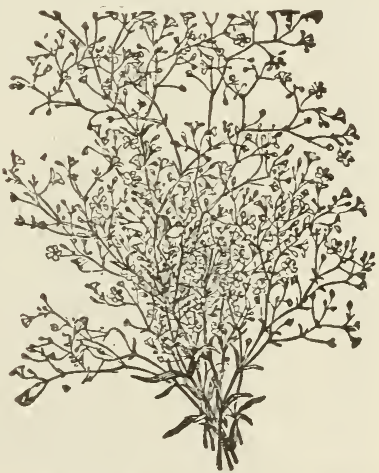

Gypopḷila, "Angel's Breath" 


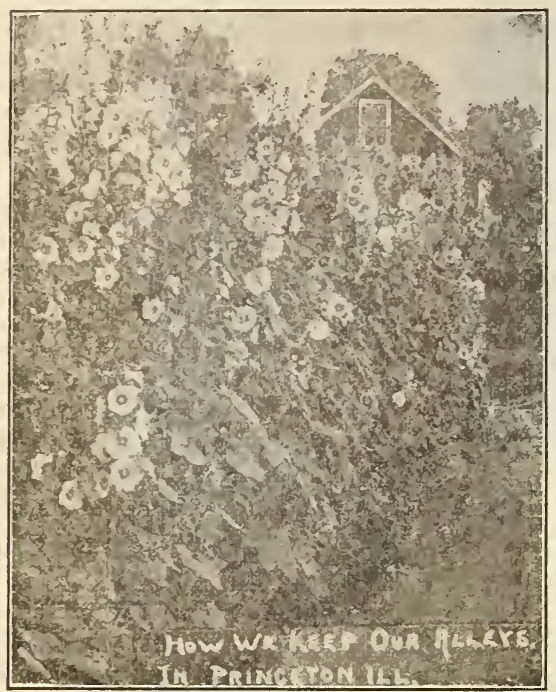

Hollyhock

\section{DOUTLE HOLLYHOCIR}

Constant experimenting by hybridizations and selections has secured flowers of extreme size and fullness, unsurpassed in beauty and variety of colors. Many are rosette-shaped and all will please the most fastidious. Price each, per packet, je.

Youble, Pink, Red, White and Yellow, separate, each, packet, 40 seeds.

Special Double Mixed. My special mixture of the above named and other English Prize Hollyhocks, all of the choicest double sorts grown. Packet, 50 seeds. 1/4 oz., 40c.

Illegheny. A handsome semi-double strain, very popular because of its long flowering season. Mixed. Pkt., 50 seeds. New Annual Hollyhocks. A new strain tliat blooms from seed the first year; also valuable for their unusually long blooming period. Mixed. Packet, 50 seeds. $1 / 4$ oz., 40e.

Single Hollyhocks Mixed. Single Hollyhocks have a much longer blooming period than double sorts. Packet, 50 seeds. 1/4 oz., 30c.

Immobium llatum. Flowers white and very double. Eeing smaller than other Everlastings, they give variety to the winter bouquet. The buds, too, are pretty and should be gathered freely. Packet, 150 seeds.

\section{HELIOTROPE}

Ielloine's Giant. A mammoth strain producing immense heads, 10 to 15 inches across, with thousands of individual florets, in all the beautiful Heliotrope shades. Pkt., 100 seeds, se. Hidnight. Beautiful dark bronze green foliage with stems as dark and black as mid-night; flowers dark purple, variegated with white and lighter purple. A handsome new variety. Packet, 100 seeds, 10c.

\section{NEW CIIMUING HELIOTROPE "ROYAI, HIGHNESS"}

A magnificent new variety of wonderfully rapid growth, forming immense plants that climb to a.height of 10 or 12 leet. It has splendid large trusses of rich purple flowers, and is a most profuse bloomer. Packet, 80 seeds, 8c. One packet each of the 3 varieties, 20.

\section{ICE PI.INT}

A trailing plant with curious foliage, covered with glossy globules, looking like minute drops of dew. Packet of 300 seeds, 5c.

\section{JAPANESE IRLD'L VINE}

A fast growing hardy climber. The first season it grows 10 feet, and later often makes a growth of 50 feet in a season. The flowers are rosy-purple and pea-shaped. In the north the top dies in winter, but in the south it becomes woody. For vigorous growth and fine shade it is unsurpassed, but is not hardy enough for the extreme north. Packet, 20 seeds, 5c.

\section{JAPANESE HOP}

For a rapid growing vine nothing is better than the Japan Hop. The foliage is luxuriant, the leaves being smaller and more delicate than those of the common hop, and curiously marked with silvery and yellowishwhite streaks. Packet, 5c.

IX̃CHIA CHLDSII, (New) Also called Summer Cypress, Fire Ball or Fire Plant. A beautiful decorative plant, growing quickly, forming neat, compact, perfectly ball-shaped bushes, which in fall turn to a brilliant red. The Childsii strain is a marked improvement on the varieties ordinarily sold. Packet. 5e.

\section{KENILWORTH IVY}

Pretty for hanging baskets. It comes quickly from seed and grows under severest neglect. Packet, 300 seeds, כe.

\section{L.IVATLRA, Splendens Rosea}

An improved form of the showy Annual Mallow. with larger and more intensely colored blooms, completely covering the large bush-like plants. Very desirable for the garden and splendid for cutting. Pink and white mixed. Packet, 50 seeds, 5c. 


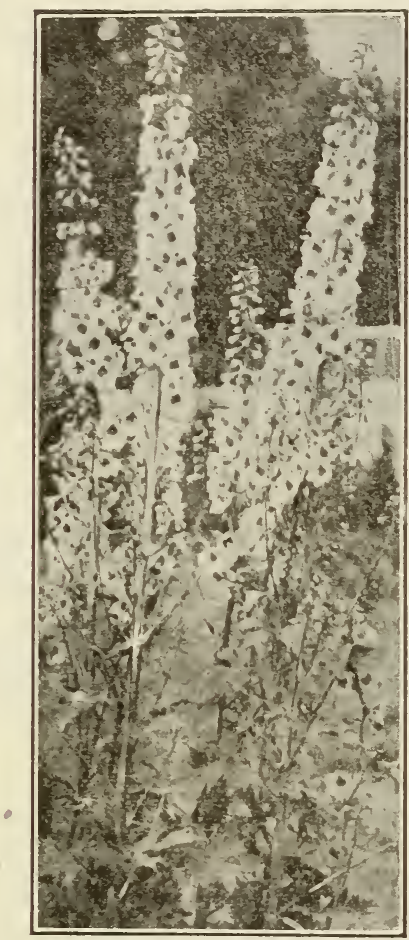

Perennial Larkspur

\section{PERENNIAL LARKSPUR (Delphinium)}

No perennial border is complete without the stately Delphinium, or Larkspur, justly one of the most popular Perennials. Our mixture contains the Formosum, or Bee Larkspur, delicate Chinese varieties (fine for cutting) and the best hybrid varieties from the famous Kelway strain. If not allowed to seed they bloom almost continually. Price, pkt., 65 seeds, 6c.

Perennial Larkspur. Light blue Shades, hybrids of the beautiful Belladonna Larkspur. Mixed. Packet, 8c.

\section{IMPERIAL LARISTUR, Annual}

Imperial Larkspur, Mixed. Very choice, improved strain, made up from special named varieties. 2 foot. Packet, 100 seeds, 5e.

\section{LOBELIA, Crystal Palace}

Much used for edgings; effective also for the hanging basket, rockery or porch box. The standard blue variety for edgings and vases. Packet, 600 seeds, Se; 1-16 oz., 20e.

\section{ANNUAL LUPINE}

Long graceful spikes of rich and variously colored pea-shaped flowers, valuable where tall effects are desired. Mixed. Packet, 5e; oz., 25e.

\section{LINARIA MAROCCANA, "Excelsior"}

Also called Annual Snapdragon. This Excelsior strain affords varied and beautiful flowers, ranging from white to yellow, pink and blue, the very best of the class. 1 foot. Packet, 10c.

\section{EUPHORBIA}

Euphorbia Variegata (Snow on the Mountain). The foliage is veined and margined with white, making the bushes like a mass of beautiful white flowers. 3 to 4 feet. Pkt., 50 seeds, 5c.

Euphorhia Mixed. Variegata and $\mathrm{He}$ terophylla, or Mexican Fire Plant, mixed. Packet, 50 seeds, 5c.

\section{HYACINTH BEAN}

Fapid climbers; ornamental in all stages, foliage, flower and pod. Price, packet, 10 seeds, 5e; any 3 packets, 12e. Princess Helen or "Daylight." Long spikes of showy white flowers, followed by equally showy white pods.

Purple, or "Darkness." Both blossoms and pods are a glossy dark purple.

Scarlet. Blush, deepening to dark red. Mixed. All the above mixed.

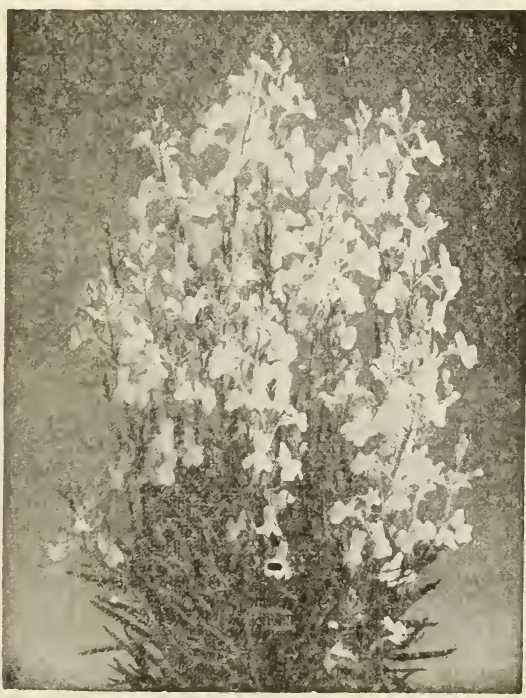

Linaria Moroceana, "Excelsior" 


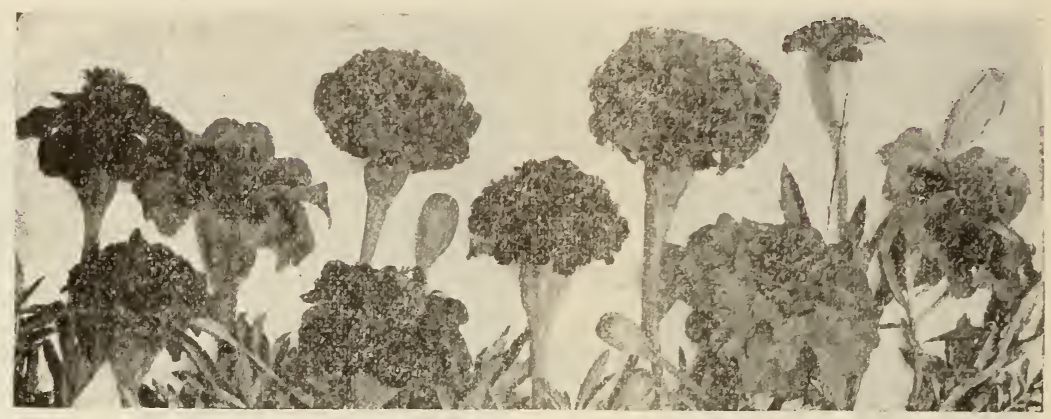

MARIGOLD

Price, packet, 5c.
MIGNONETTE

Price, each, per packet, 5c.
Tall Double African-Orange Ball. Large, perfect double-quilled flowers of a rich deep golden orange color; the finest of all and very showy. $1 / 4$ oz., 40e.

Tall Double African-Lemon Ball. A counterpart of the Orange Ball except in color, which is soft lemon yellow. $1 / 4$ oz., 40c.

Dwarf Single French, Legion of Honor (Little Brownie). Compact bushes 9 inches high, flowering June to Frost; color, golden yellow, marked with a large spot of velvety crimson at base of each petal. Best for edging. $1 / 4$ oz., 20e.

Tall French Marigold, Mixed. Plants grow as tall as the Eldorado, but the blossoms are small like those of the Dwarf French, blooming till latest frosts. Splendid for cutting. Packet, 100 seeds.

Dwarf French, Selected. Mixed. The Dwarf Marigolds form ornamental little bushes about one foot high, and are especially suitable for window vases, bordering walks or edging of beds. In bloom till late fall. Gold edged, spotted and dark shades. 100 seeds in packet.

Collection No. 240-1 full packet each of the five varieties, 20c.

\section{MAURA NDIA VINE}

One of the prettiest things I have seen was a little cottage embowered in Meurendia Vine. Used also in pots for the window. Mixed. Packet, se.
Alen's Defiance. The finest and most fragrant variety yet produced, the favorite for cutting. Packet, 250 seeds. $1 / 8$ Oz., 15c.

Mixed Mignonette. A splendid mixture, including our named varleties and others of the newest sorts. Packet, 300 seeds, 5c; 1/8 oz., 12c.

\section{MOONFLOWER VINE}

Early Giant Noonflower. The Southern Moonflower, of whose beauty and fragrance so much is told. This is a new hybrid variety from 40 to 60 days earlier than the old style, bearing just as large and beautiful flowers. It comes into flower in the extreme north about August 15, from seed sown May 1. Starting it indoors gives a longer period of bloom. Packet, 8 seeds, Sc.

Giant Pink Moonflower. Of marvelous growth, the plants beginning to bloom nearly as soon as the Morning Glory. They remain open from four o'clock in the afternoon until about noon the next day, and cover the vines all summer and fall. Packet, 8 seeds, $8 c$.

\section{FOR SHADY PLACES}

Achillea, Alyssum, Anchusa, Anemone, Arabis, Asperula, Bachelor's Button, Fegonia, tuberous-rooted, Chinese Primrose, Calendula, Canterbury Bell, Chrysanthemum (annual), Columbine, Coreopsis, Daisy (English) Eschscholtzia, Feverfew, Forget-Me-Not, Foxglove, Godetia, Larkspur, Maurandia, Mignonette, Mimulus, Oenothera, Pan. sy, Petunia, Pinks, Poppy, Snapdragon and Violet. 


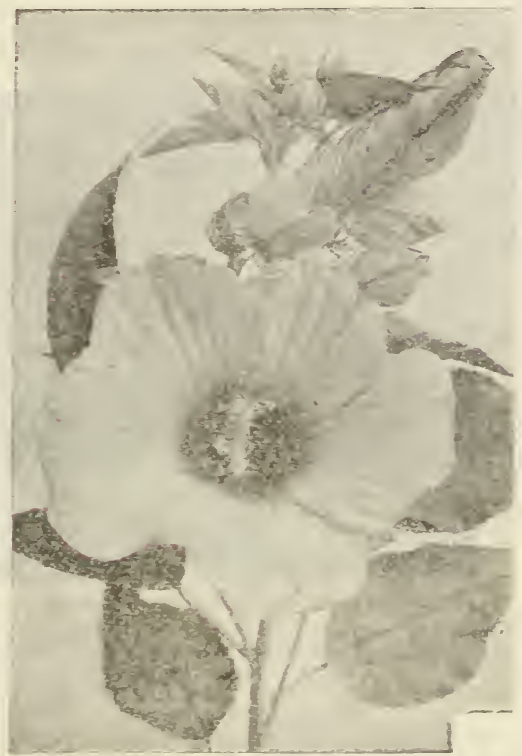

NEW RAISBOW MARTELS

splendid new hybrids of the garden Hibiscus. Tery hardy, blooming profusely from mid-summer until frost, bearing large hollyhoch-shaped flowers in various tints of red, pink and white, some solid in color, others with dark velvety centers; one of the few perennials that bloom the first year. The plants die to the ground each year and are late to start, so the root clumps should not be disturbed in the spring. 4 feet. Packet, 25 seeds, Sc.

\section{MORYIXG GLORY}

Price, each, per packet, 5e.

Morning Glory, Mixed. The old-fashioned, common, Morning Glory. A splendid mixture of named varieties. Packet, 75 seeds, 4c; oz., 10.

Brazilian Morning Glory. Very ornamental, because of the hairy appearance of the leares and the tiny brown spines that cover the branches and stems; rose colored flowers. Packet, 7 seeds.

\section{VOR.IVG GLORI}

Double White Tassel Morning Glury. The vines are great climbers and are covered with pretty, fringy white blossoms, proving very effective. Packet, 15 seeds.

Heavenly Blue Morning Glory. Large beautiful shy-blue flowers. Sow seeds indoors and transplant outside when warm. Packet, 7 seeds.

Japanese Morning Glory. The rich, velvety colorings of the common Morning Glory are intensified in these gorgeous varieties. Mixed. Packet, 50 seeds, $1{ }^{\prime}$ oz.. 10e.

Rochester Norning Glory. Tick's introduction, remarkable for size, beautiful color and prolific bloom. The throat is violet blue, blending to azure blue with white border. Pacliet, 15 setds.

Vorning Glory Collection 3o. 260-One packet each of the above seven varieties, 6 whole packets for 22c.

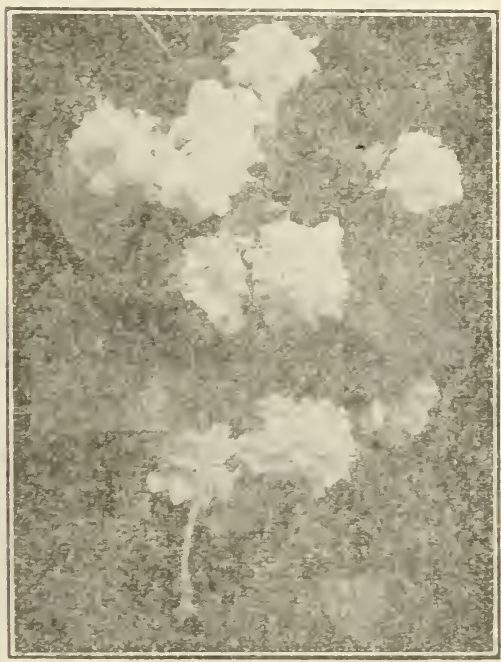

Morning Glors

Donble White Tassel 


\section{WILD CUCUMBER}

This well-known climber has so many favorable qualities-easy of cultivation, rapid growing, dense foliage, graceful blossoms, self-sowing - that we cannot do without it. Packet, 20 seeds, 5c; oz., 25c.

\section{SC.IRIET IRUNER BEANS}

Highly ornamental as well as useful both in foliage and flower and as pretty a climber as many of its more aristocratic neighbors, and the beans are good for the table if one wishes, Packet, 12 seeds, 5e; oz., $10 c$.

White Runner Beans. Blossoms pure white. Packet, 5c; oz., 10c.

\section{RAINBOIV CORN (Japanese Maize)}

An improved, fancy strain, as beautiful and decorative as the Dracaenas. In some the leaves are variegated like those of the striped grass, in others there will be broad stripes of crimson, yellow, white and other rainbow colors. Nothing like it for decorative purposes, either for the garden or for cutting where large effects are desired, or in the center of a tropical bed, or a screen against a fence, or a background in a border. 4 feet. Packet, 25 seeds, 5e.

\section{ORNAMENTAL PEPPERS}

The cultivation of small-fruited peppers for the window or ornamental garden is exciting much attention, and there are many new and odd sorts which are interesting to grow besides being of use for seasoning, etc. This mixture contains the popular Christmas Pepper, and other varieties, such as Cayenne, Red Cluster, Red and Yellow Cherry, Yellow Plum, Kaleidoscope and Red Chili, small scarlet, used for "pepper sauce." Mixed. Packet, 100 seeds, эе; $1 / 4$ oz., 1ӟ.

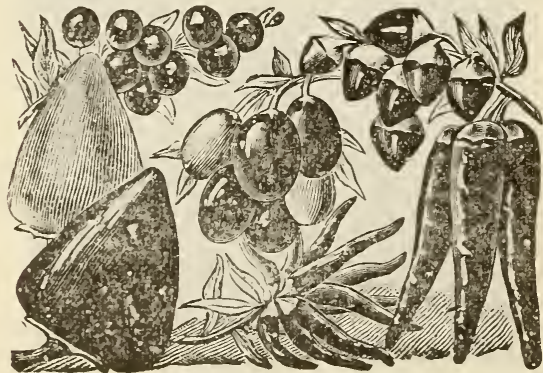

Ornamental Peppers

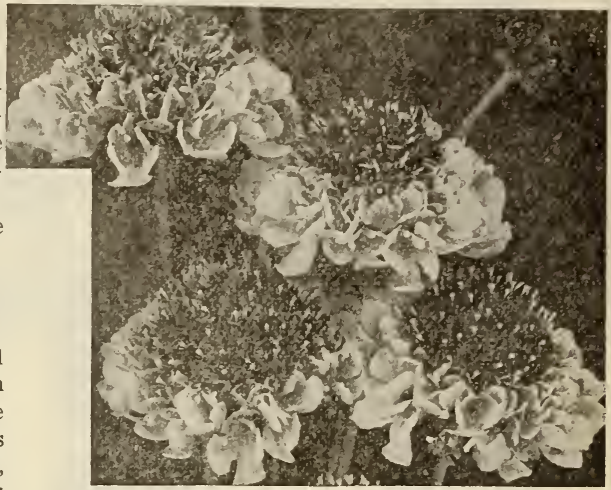

MOUINING BRIDE (Scabiosa)

Our own special mixture of named varieties, the very best I can offer. Valuable for cutting and for exhibition purposes. $2 \frac{1}{2}$ feet. Pkt., 60 seeds, 5c. Separate Colors

Lilac, Rose, Scarlet, Purple, Yellow and White. Packet, oc.

Collection No. 111-6 full packets, 22c.

\section{MIMULUS or "Monkey Flower"}

Showy, profuse, flowering plants, with Gloxinia-like blossoms, fine for the winter garden, or for moist, shady positions. A mixture of Tigrinus, or true Monkey Flower, and Musk Plant, noted for its fragrant foliage. Packet, 500 seeds, 5c.

\section{NICOTIANA}

Nicotiana Affinis. The Sweet-scented Nicotine or Tobacco Plant. It will bear continuously an abundance of large pure white flowers of delicious fragrance, 2 to 3 feet. Packet, 500 seeds, 5с; 1-16 oz., 15c.

Nicotiana Sanderae Irybrids. Small graceful flowers, in many shades of crimson, purple, carmine, pink or mauve, 2 to 3 feet. Mixed. Packet, 200 seeds, 5e.

Nicotiana Mixed. A mixture of the above two sorts and other popular varieties, 2 to 3 feet. Mixed. Packet, 500 seeds, 5e; $1-16$ oz., 20c.

\section{NIGLLLA}

"Love in a Mist," or "Ragged Lady." Varying shades of blue or violet flowers, charmingly imbedded in lacy, fernlike foliage. Mixed. 1 foot. Packet, 50 seeds, 5c. 


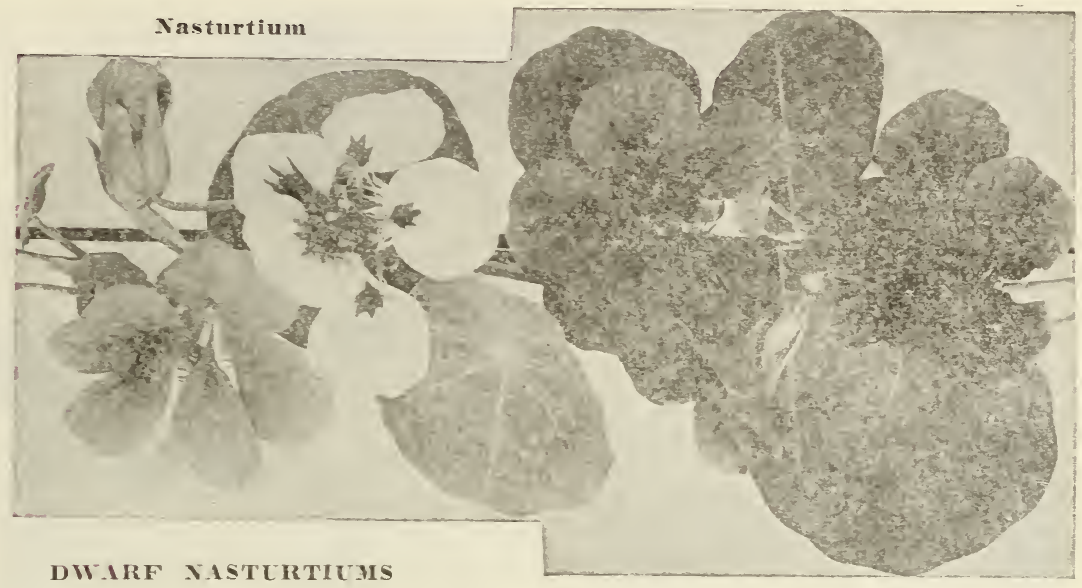

Price, each, per packet, 25 seeds, ฮ̃c; $1 / 2$ Oz., 10c.

TALL, OR CLIMBIYG

spotted king, or Ladybird. Indian yellow, spotted cardinal red, calyx and spur ruby.

Iurora. Terra Cotta.

Empress of India. Dark scarlet and dark leaved.

Crystal Palace Gen. Sulphur spotted red.

Pearl. Light cream, nearest to white. Golden Queen. Bright yellow, golden leaved.

King Theodore. Telvety maroon.

Vesuvius. Brilliant salmon pink.

Yixtures of Dwarf Nasturtiums Dwarf Iry-Leaved, Mixed. Distinct Iry-shaped leares, with fringed flowers. Packet, 25 seeds, 5c; 1/2 oz., 10c; oz., 15e.

Dwarf Liliput, Mixed. Extra, dwarf, dense bushes almost hidden by the mass of bloom standing well above the foliage. Especially adapted for edgings. Packet, 25 seeds, 5c; $1 / 2$ Oz., 10c; Oz., 15 c.

\section{Our Special Dwarf Mixture}

Especially prepared for us from named sorts, including all the dwarf sorts described on this page as rich and raried an assortment of colors as any other mixture offered. Packet, 25 seeds, 5c; $1 / 2$ Oz., 10c; Oz., 15c.

\section{Nasturtium Collections}

Dwarf Collection No. packet of each of our eight named dwarf varieties for $\mathbf{3 9 c .}$

Tall Collection vo. 271-One full packet of each of our six named tall varieties for 25c.

The two collections for 50c.
Price, each, per packet, 25 seeds, je; $1 / 2$ oz., 10c.

Giant of Battles. Sulphur yellow, blotched red.

Jupiter. Best deep, golden yellow.

King of Blacks. Dark crimson maroon.

Moonlight. Exquisite light creamyellow.

Fimbriata. Beautiful fringed varieties.

Twilight. Rose or salmon-rose.

\section{Mixtures of Tall Vasturtinus}

Giants of California. Large-flowering strain of many choice varieties. Packet, 30 seeds, 5e; 1/2 Oz., Sc; Oz., 12e; 1/4 lb., 35e.

Tall Ixy-Leaved, Hixed. Peculiar ivyleaved foliage and fringed flowers. Packet, 25 seeds, је; $1 / 2$ oz., 10c; oz., 15e.

Tall Variegated-Ieaved, Mixed. Leaves variegated with yellow, white and green, affording something new for decorating. Packet, 25 seeds, 5e; 1/2 oz., 10e: oz., 15e.

\section{Onr Special Tall Mixture}

For richness and variety of color this cannot be excelled. We make it ourselves and include all the tall varieties named on this page and many others. Packet, 25 seeds, 5e; 1/2 oz., 10c; oz., $15 \mathrm{c} ; 1 / 4$ lb., 45c. 


\section{GIANT I'A ISILS \\ EXHIBITION INININS}

Especially selected. Whe are offering this season, in this carefully selected strain from only the largest and most perfect flowers the lwet l'ansy strain we have ever sold. It includes our attractive frilled vinetripiese, the many unusual shades of Mrilam l'erret, or Fed Pansins, and 711 onr other charming named varietics of the Giant-flowering sorts, and is unexclled in size, variety and beauty of hluom.

Canon ('ity, Colo., June 1st, 1920. "My I'ansy plants from your seeds are producing the most. Wonderful blossoms I haw" (ver sen. Miss A. G." Packet, 100 sofis ïe. Trade packet

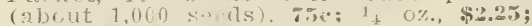
$02 ., \$ 5.63$.

72A A

Oux Mammoth 1,esthell P'insy Mixture afiords a chance to get the cream cfthe latest and locst sorts at a moderat outlay of money and time. It includes several famous strains of Giant Pansies, each with givat center blotches on the three lower, or all five petals, with edges of contrasting colors, sometimes solid, sometimes delicately veined and frilled. A splendid mixture. Packet, 100 seeds, 10e. Trade packet (about 1,000 seeds), כ0e.

DANISI BEAUTUES, OR WREDES Remarkably beautiful new strain of pansies in mixture, composed of rich self-colors and large flowers with curled petals. A bed of this class creates a peculiarly bright and light appearance. Packet, 100 seeds, 10c. Trade packet, $75 \mathrm{c}$.

Collection No. 113-One packet each of Giant Exhibition, Mammoth Blotched and Danish Beauty Pansies, 28e.

\section{GIANT NAMED PANSIES}

Plit., 100 seeds, each, 10e; 3 plits., 25c. Giant Blue. A splendid dark blue of immense size, the very best in blue. Giant IB1:ck. New, nearly all jet black, very rare.

Giant Bronze. The popular art shades ranging from burnished brass to old gold.

Giant Masterpiece, or Giant Frilled, giving the flower a unique, double effect. All colors mixed.

Giant Red, or Madam Perret. Dark wine, pink and red, beautifully veined and frilled.

Giant inite. The finest and largest all-white pansy grown.

Giant Yellow. Huge, deep yellow, some with dark centers, some all yellow. Tery showy.

Giant Lord Heaconsfield. Deep purple violet shaded to white.

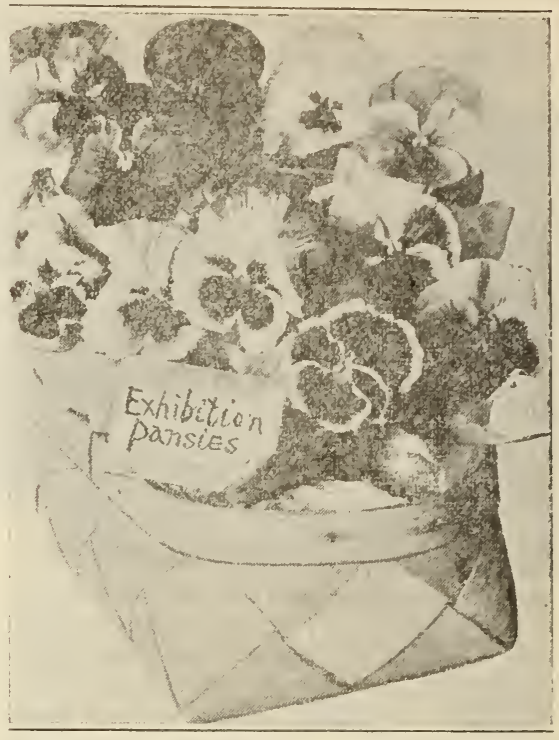

SWEET SCENTED PANSIES (Viola Cornuta)

Or Tufted Pansy. The latest fad in parks and gardens. They are a cross between the pansy and the violet, and have the delightful perfume of the latter with blossoms more like the pansy only much smaller. Plant them in masses and they will cover the beds with sheets of bloom throughout the season. Mixed. Pacliet, 100 seeds, 6c.

\section{FINEST MIXED PANSIES}

A splendid mixture, including all the best bedding varieties, together with numberless other shades and combinations, a rare mixture. Packet, 100 sceds, 5c. Trade packet (1,000 seeds) for 30e.

\section{NOLANA, or IITTLE BELLS}

Charming trailing plants for pots, rock work or hanging basliets, with pretty bell-shaped, blue flowers. Packet, 75 seeds, 5ீ.

\section{SENSITIVE PLANT}

Cultivated for its curious habit of closing its leaves at the slightest touch. Children always enjoy it. Tender annual. Packet, 40 secds, je. 


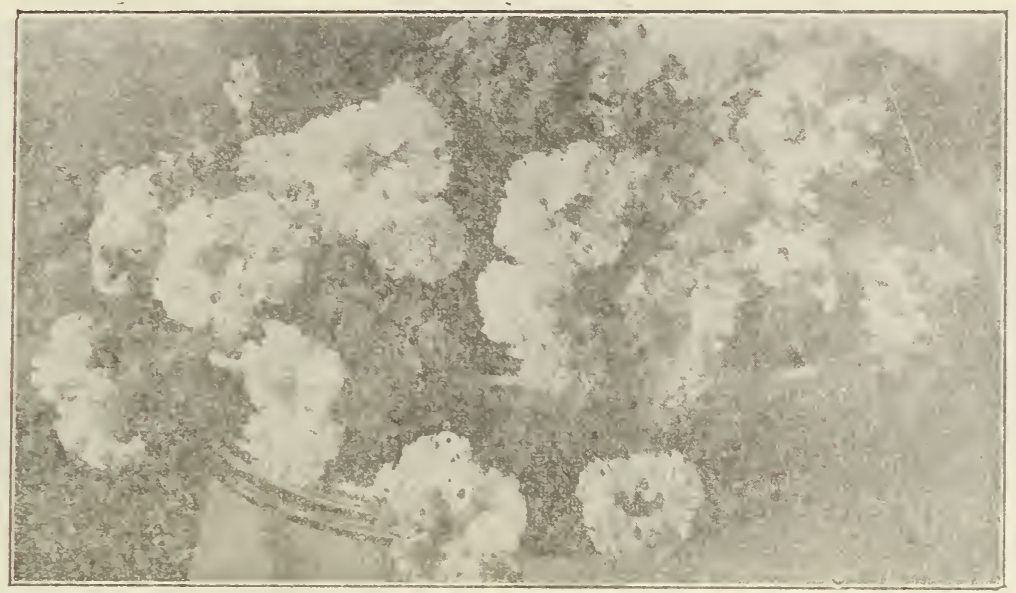

Petunia, "Flufiy Fuffles"

\section{LARGE FLOWERING PETUNIA}

Giants of California, Double Mixed. Mrs. Wadsworth, a New York customer, says: "The Double Petunias were the handsomest I ever saw. I had 15 rarieties and took first prize at our fair." Our mixture contains the very best strains of two expert growers who have devoted years to their development. Not all come double, but the seed will give a good percentage of deeply fringed, double flowers, in the brightest colors and most beautiful tints. Packet, 75 seeds, 15e.

Giants of California, Single Mixed. This mixture will give as handsome Petunias as any on the market. Some will measure four or five inches across, the corollas being ruffled, fluted or fringed. With extremely deep and large open throats. They appear in many shades and combinations, striped. blotched or solid in color. Splendid mixed. Pkt., 150 seeds, 10c.

"Flufiy Rufles." A superb strain of single petunias, the most deeply ruffled and fluted of all. Exceedingly delicate and graceful. Mixed. Packet of 100 seeds, 10c.

Balcony Queen. Large flowering or Grandiflora, rich dark velvety purple, one of the best plants for window boxes or group planting. Use white flowers with the Balcony Queen for best effect in window box. Packet, 15c.
BEDUNG P'PUNAS Price, each, per packet, 5c.

Petunias, Blotched and Striped

Beautifully striped and mottled, including Howard's Star, the handsomest starred variety. Exceptionally fine for basliets, vases or for massing. Packet, 400 seeds. 1-16 oz., $15 \mathrm{c}$.

\section{Petunia, Liliput, Mixed}

"Dwarf Inimitable." Compact plants covered throughout the season with richly self-colored, starred and mottled flowers; best for bedding. Packet, 400 seeds. 1-16 oz., 15c.

Petunia, Rosy Morz. Splendid for bedding, potting or edging. The little plant is covered with myriads of delicate pink flowers throughout the season. By far the handsomest named variety and a decided rose-pink. Packet, 300 seeds.

Snowball ['etunia. Dwarf plants with myriads of pure white flowers; fine for an edging. Packet, 300 seeds.

\section{SPECIAL MIXED PETUNIA}

All our single strains mixed. Packet, 400 seeds, 10e; $1-16$ oz., 30.

Violacia. Bedding strain of the Balcony Queen, plants and blooms smaller. Plit., јe. 


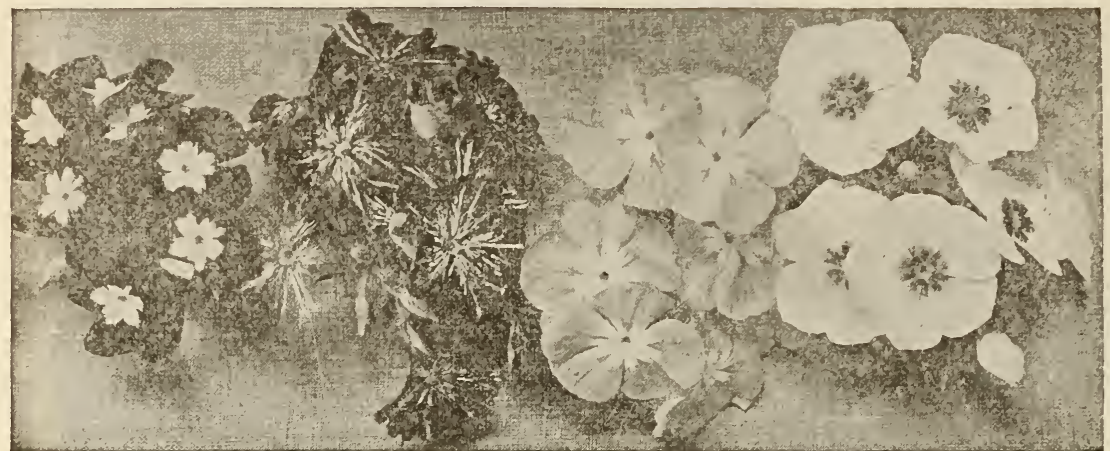

\section{GRANDIFLORA PHLOX}

The Phloxes are the showiest and most easily raised of all annuals. The Grandiflora is a large-flowering strain, both the single florets and the flower heads being very large and showy.

Price, pkt., 150 seeds, 6c; 3 pkts., 15c. Phlox, Salmon-Pink. Very effective in a mass by itself, or with white.

Phlox, Searlet. Almost as handsome for bedding as Geraniums.

Phlox, White Perfection. Pretty for the cemetery or design work.

\section{DWARE PHLOX}

The plants grow quite compact, the blossoms forming a floral crown for each little plant which will last for weeks. Splendid for edgings and ribbon bedding. Price, packet, 100 seeds, 6c.

Dwarf Pliox, Red. Blood red.

Dwarf Phlox, White. Pure white.

PHLOX, SPECIAL MIXED

All the preceding sorts and many other special cololrs mixed. Packet, 150 sceds, 6c.

\section{DOUBLE POPPY}

Packet, 500 seeds, 5e; any 3 packets, 12; $1 / 8$ oz., 1 5e.

Double Scarlet. Brilliant red.

white swan. Pure white, fringed edges.

Double Mixed. Splendid mixture of strains of Paeony-flowered, Carnationflowered, and almost every variety of double poppy grown.

\section{SIYGLE POPPY, Special Mixed}

In the craze for double flowers, the equally, and often more beautiful, single varieties are neglected. This splendid mixture includes the newest and best sorts, such as Shirley and several other choice named varieties. Packet, 500 seeds, 5e; 1/8 oz., 10.

\section{SHIRIEY POPIIES, Acme Mixture}

In an effort to offer the very best in this most popular poppy, I have prepared for this mixture a strain that cannot be excelled. Nothing makes a more beautiful display, either in the garden or for decorating, than the Shirley Poppy. They range from pure white and delicate pinks to rich, gaudv hues-all of so sheeny a lustre as to be called Silk or Ghost Poppy. One of the prettiest table decorations we have seen was a dainty basket of Shirleys. If picked before the sunshine strikes them, and base of stems dipped in boiling water, they last two or three days. No better assortment than ours. Packet, 500 seeds, 5c; $1 / 8$ oz., 15c.

\section{PERENNIAL POPPY}

Iceland Poppy, "Excelsior." The Iceland Poppy is among the earilest of spring flowers, and if not allowed to seed it stays with us a long time. It comes in shades ranging from white to deep orange-scarlet. double and single, with petals beautifully crinkled, like soft crepe paper. Pkt., 6c;1-16 oz., 15c. Iceland. Select double mixed in all the existing colors. Packet, 10c.

Oriental Poppy, "Excelsior." A special strain of these gorgeous flowers with their numerous blossoms in scarlet, crimson, orange and salmon shades. A grand mixture. Pkt., 6c; 1-16 oz., 15c. Oriental, Princess Victoria Louise. A beautiful salmon red. Packet, 10c.

\section{PopPIES, Special Mixed}

All our single and double annual varieties mixed. Packet, 400 seeds, 4c; 1/8 oz., 10e.

\section{COLLECTION OF POPPIES}

Dne full packet of each of our mixed sorts, double. Special Single, Shirley, Iceland and Oriental, five packets, 20c. 


\section{CHINESE PINKS \\ Dianthus sinenses}

Price, each, pkt., 200 seeds, 5c.

Fireball. A splendid new rariety. a dark blood red, very double.

snowdrift. A large double white.

Eastern Queen. Beautiful single variety with rose and white marbled flowers.

Double Diadem Mixed. Large double flowers, petals fringed and marked with a broad white edge.

\section{Imperial Chinese, Double Iixed}

Giant Heddewigi, or Japanese single Iixed. Finest selected single-flowered; mixed.

Collection, 6 full packets, $\mathbf{2 5}$.

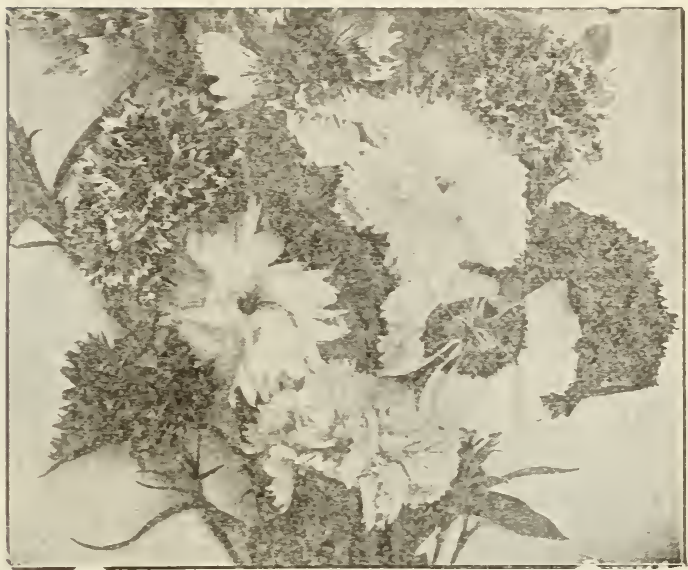

SCOTCH OR GRASS PINK

A magnificent new strain of perpetual blooming Pinks, with colors of exquisite beauty, and marked by a deep relvety-red ere and a cloverlike odor. Double and single, mixed. Packet, 75 seeds, 6c.

\section{PINKS, SPECIAL MIXED}

All the preceding kinds, mixed (excepting Scotch Pink). Packet, 200 seeds, 5c.

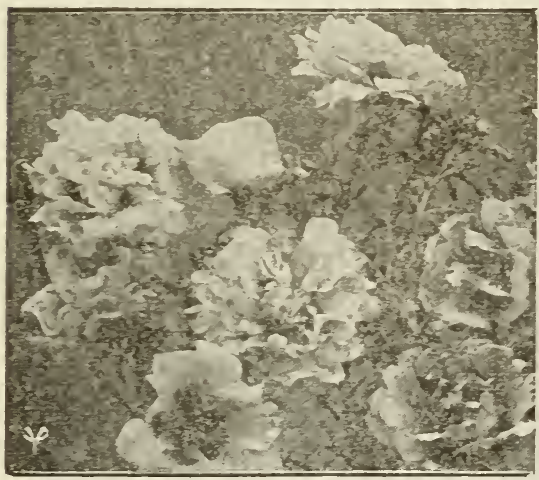

PORTLLACA, or Moss Rose

Double Portulaca. Mixed. Low trailing annuals, with double flowers like charming little roses. Many brilliant colors. Pkt., 200 seeds; Sc: 1-16 oz., 30c. Single Portulaca. Mixed. Pretty to mass in a bed or on some sunny slope. Packet, 400 seeds, 5̌c; $1 / 8$ oz., 10c.
Hardy Chinese and Scotch Pinks

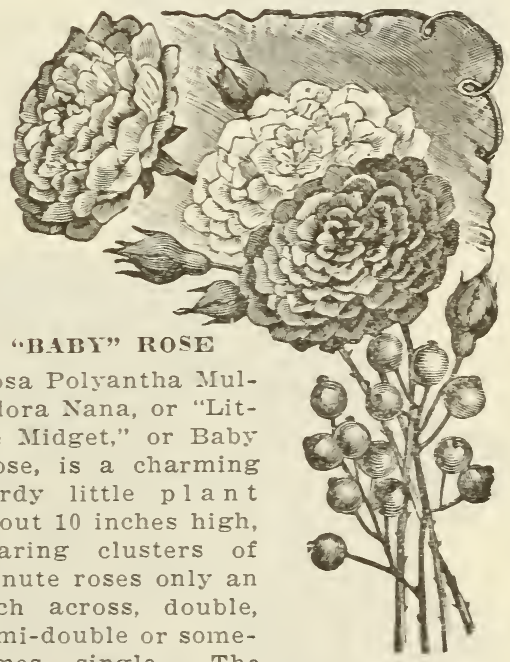

many flowered clusters look like a mass of double crab-apple blossoms. Te have taken pains to secure the best seeds and true to name. Not all the Rosa Polyantha seed is of this dwarf, early-flowering variety. It blooms the first season, though not attaining perfection until the second year. Packet, 35 seeds, $8 c$. 


\section{PJIE'IHILU IXIBIDUM}

'This class of Pyrethrum is greatly valued an account of the beautiful flowers it furnishes for cutting. The plants are hardy perennials of the easiest culture, and reach the height of two feet. They come in charming shades of red, white and pink and are wonderfully lasting when cut. Selected seeds, grown for us by a well known Danish flower seed specialist.

Superb mixture, saved from a grand collection of named varieties. Packet, 10c.

\section{SMILAX}

No climbing plant surpasses the Smilax, not only for the graceful beauty of the vine but for its value in decoration. Packet, 60 seeds, 5̃c; $1 / 8$ oz., 15c.

\section{STOKESIA CYANEA}

The Cornflower Aster, New Hybrids. Blue Stokesia is well known, but these new sorts, saved from blue, white, yellow and purple varieties, will give many attractive shades and tones, entirely new. Hardy perennial, 18 inches. Packet, 25 seeds, 5e.

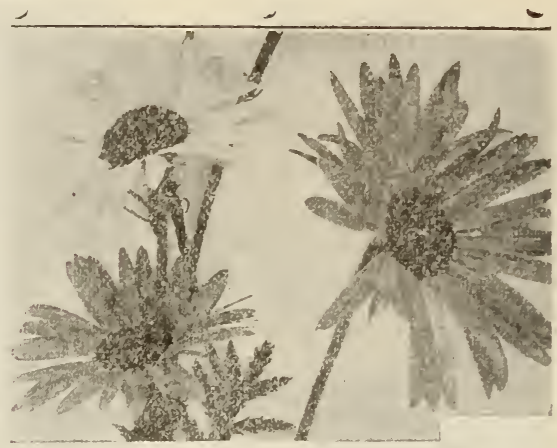

Pyrethrum Hybridum

SWEET-SCENTED S'TOCKS Evening-Scented Stock, Matthiola Bicornis. An old-fashioned annual with purplish flowers which emit a delicious fragrance during the evening and in early morning. 15 inches. Packet, 5c. Virginia Stock. Pretty annuals, blooming early in the season in fresh, bright colors and with sweet odor. Mixed. 6 inches. Packet, 5c.

\section{PRIMULA, Fringed Giants} (Chinese Primrose)

Primulas are easily raised from seed. See our "Culture of Flowers" for directions. They bloom year after year, but as new plants bloom more freely it is well to sow seed every year.

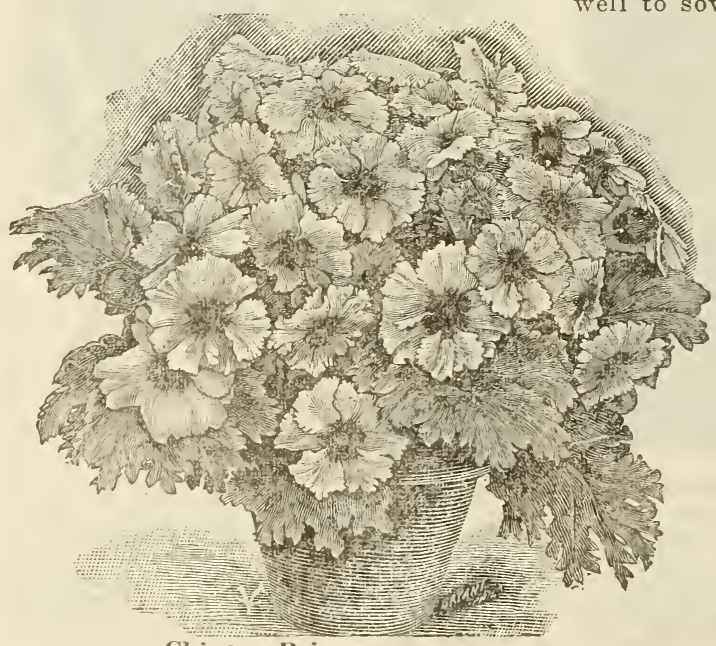

Fringed Giants, Mix ed. Splendid mixture of new fringed varieties, including our three named sorts. Packet, 40 seeds, 8c.

Primula Malacoides. The new Baby Primrose, with a profusion of lavender or white flowers, borne in whorls, along tall, graceful spikes, blooming in 4 to 5 months. Packet, 10c.

Primula obconica. An almost ever-blooming species. The blossoms are lilac-tinted, in showy clusters of from ten to fifteen flowers in a bunch. Packet, 150 seeds, 10c.

Hardy Primrose (Polyanthus). Low-growing perennials, hardy except in extreme north. A choice mixture. Packet, 10e. 
SALVIA SPLENDENS (Searlet Sage)

Price, any pkt., Se; any 3 pkts., 20e.

America, or Globe of Fire. Unquestionably the finest of all Scarlet Sages, being uniform in growth and coming early into bloom, remaining in good shape till the close of the season, Packet, 30 seeds.

Salvia "Bonfire." Also listed as "Clara Bedman." The plants form a symmetrical, oval bush from 2 to $21 / 2$ feet high, with large spikes of brilliant scarlet flowers, not infrequently 200 to a plant. By far the best variety for bedding. Packet, 60 seeds, 1-16 oz. (about 750 seeds), 25c.

Salvia Grandiflora. The original tall Salvia, with long spikes of brilliant scarlet. Taluable where tall effects are desired. 3 feet. Packet, 60 seeds, 1-16 oz., 25e.

\section{IIARDY SALVIAS}

Salvia Farinacea. The foliage is silvery-gray and it bears, throughout the season, hundreds of long spikes of a silvery lavender-blue, flowering the first season. Tery showy and attractive. 3 feet. Packet, 75 seeds, 6c.

Salvia Argentea. Silver-leaved Salvia. Prized for its showy, woolly-white foliage growing in a large tuft. The second year a tall spike is thrown up, crowned with a heavy panicle of whitish flowers. Biennial. Packet, 50 seeds, fe.

\section{SALPIGLOSSIS}

A splendid large-flowering mixture of this popular flower, which we make ourselves from named varieties, and we know that you cannot get anything any better or tliat will give greater variety. You will find yellow, orange, crimson, bronze, lilac, blue, purple and almost black shades, the petals in each being beautifully marbled and penciled. Annual. $1 \frac{1 / 2}{2}$ to 2 feet. Packet, 400 seeds, је; 1 -16 oz., 15е.

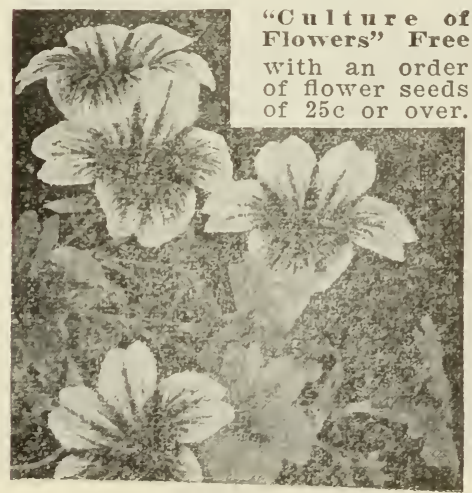

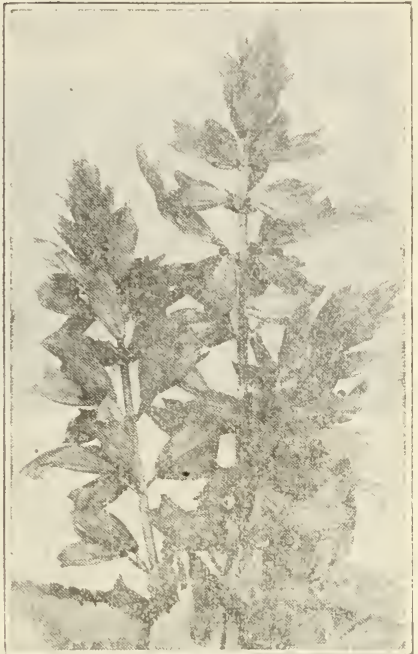

SALVIA

\section{SUNFLOWER}

Price, per pkt., 40 seeds, ãc; any 3 pkts., 12e. Chrysanthemum-Flowered. Magnificent flowers 4 to 6 inches in diameter, very double, with long fringy petals. 5 to 6 feet.

Double Mixed. A choice mixture, containing Mammoth Globosus Fistulosus, the Chrysanthemum-Flowered and several other sorts.

Single Mixed. New types of the Stella, or "Cut and Come Again" Sunflower. The plants are branching and bushy and the flowers are like great yellow daisies. All fine for cutting. 3 to 5 feet.

Special Mixed. A mixture of the above. An opportunity to try all our choice sorts.

\section{NEVV RED SUNELOUVERS}

A really unique Sunflower. Plants are from 5 to 8 feet high and much branched, with fiower heads varying greatly in size and color. Some produce rich chestnut-red blooms, some full rose, some red, tipped yellow, and others will be zoned with red, all very striking, though, as in most novelties, not every seed will come true.

New Rainbow Sunflower. Obtained by blending three distinct types. The colors run through all shades of yellow in many combinations with brilliant reds and bronzes. A row will make a gorgeous sight in your garden. Packet, 15 seeds, 8c. 


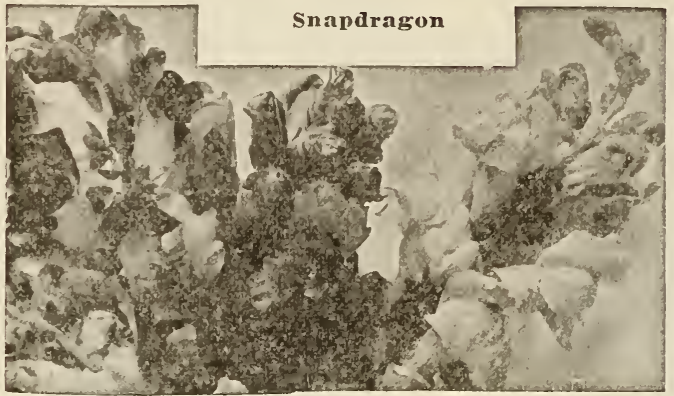

GIA NT SNAPDRAGON

One of the finest bedding plants, being constantly in bloom throughout the summer. Should be started early. 1 to $1 \frac{1}{2}$ feet. Price, each, per packet, 300 seeds, Јc.

Cottage Maid. Pink, white throat. Crimson Queen.

Defiance. Orange red.

Fawn. Terra Cotta pink and pale yellow; extra fine.

Golden Queen. Rich deep yellow.

Queen of the North. Pure white.

Firebrand. Rich deep red.

Collection No. 115-One full package each of the above 7 sorts, 28e.

Mixed Tom Thumb. This class produces pretty little bushes about six inches high and are specially adapted for edging.

Giant Mixed. A splendid mixture of these old fashioned favorites, including those named above, and many other brilliant shades. 1-16 oz., 15c.

\section{THUNBERGIA}

Pretty annual trailing plants for hanging baskets, vases, rock work or low fences. Flowers in buff, white or orange, with dark eyes, giving them the common name of Black-eyed Susans. Packet, 20 seeds, כ̌c.

\section{PERILLA}

A Coleus-like decorative plant, with ornamental leaves sometimes of bronzy purple, others of an extra deep reddish purple and many with frilled edges. Pretty for the border where tall effects are desired, or to edge a bed of Cannas or Castor Beans, $1 \frac{1}{2}$ feet. Packet, 100 seeds, כ̄e.

\section{VINCA ROSEI}

A tender perennial, blooming the first summer, used for the window or for bedding out. Blossoms are white or white with crimson center, or all crimson. Very profuse bloomer, continuing from early summer until frost. 20 inches. Packet, 100 seeds, 5c,

\section{GIANT SPIDER PLANT}

Sometimes listed as Electric Light Plant. A tall, bushy annual, each branch crowned with a huge, showy cluster of white or lilac flowers, which throw out long stamens curiously like spiders' legs. Use it in clumps, in beds with tall decorative plants, or as a screen. Bees like it and hover about it all day. Blooms from July until frosts. 3 to 5 feet. Packet, 75 seeds, 8c.

\section{WALLFLOWER}

Double Mixed. Extra choice. Packet, 25 seeds, 5c.

\section{SWEET WILLIAM}

Price, any packet, 5c.

Hardy Perennial. Height, 1 to $1 \frac{1 / 2}{2}$ feet.

The Three Beanties. A mixture of three new sorts, Black Beauty, dark crimson-maroon; Pink Beauty, splendid pink shades, and Scarlet Beauty, same color as the Christmas Poinsettia. Double Mixed. Beautiful, large-flowering varieties, solid, margined, and star-eyed, in white, lavender, pink, crimson and deepest velvety red.

Special Mixed. The above and other choice varieties; splendid mixture.

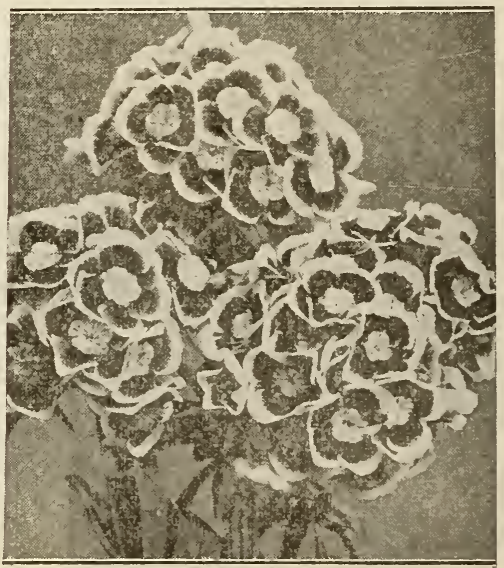

Sweet William 


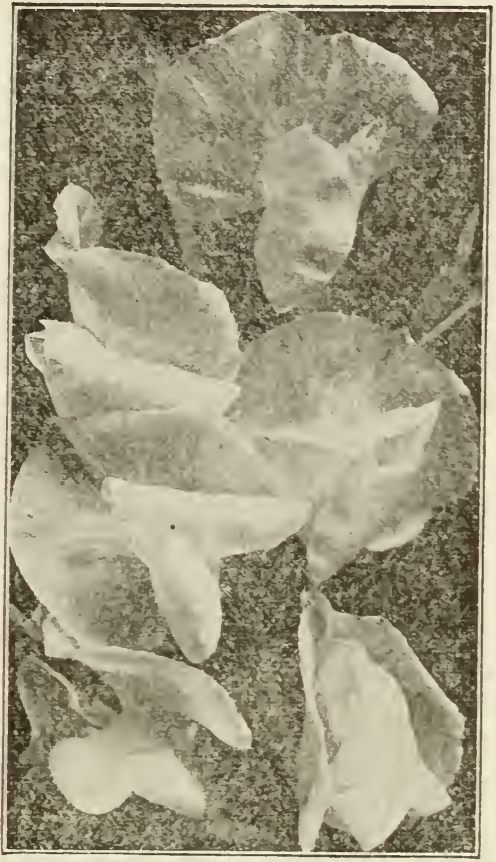

spencer sweet l'ea

EIRLY FLOWERING, LONG SEASON SPEYCER

Large waved flowers of the Spencer type, in bloom at least three weeks earlier than the ordinary Spencers and continue to bloom for a much longer period.

Early Ista Ohn. Lavender. Packet, 15e; $1 / 4$ Oz., 30e; Oz., \$1.00.

Early Liberty. Nammoth crimson. Packet, 15c; 1/4 oz., 25e; oz., 80c.

Early Melody. Rose pink. Packet, 15e; $1 / 1$ OZ., 20c; OZ., 65̄e.

Early Pink and White. Blanche Ferry type. Packet, 15e: 1/4 oz., 20c; oz., 65e. Early White Orchid. Large waved white. Packet, 15e; $1 / 4$ oz., 20c.

Early Songster. Beautiful lavender Packet, 15e: 1/4 oz., 25e; oz., 85e.

Early Songbird. Pale blush pink. A packet, 15e; 1/4 oz., 20e; oz., 65e.

Early Yarrawa. Bright rose pink with white wings. Packet, 15e; $1 / 4$ oz., 20e; oz., 6อ̄e.

Mixture of the above and other early flowering Spencer varieties. Packet, 15e; $1 / 4$ oz., 20e; oz., 65e.

"Exhibition" Collection No. 350-One packet each of 8 varieties of Early Flowering Spencers for $\$ \mathbf{1 . 0 0}$.

\section{SWEET PEAS}

Sclected Giant Spencer or Orchid Flowering

Our list includes 25 desirable standard sorts, tried varieties. All have the ruffled or wary effect that marks this unique and beautiful type. Price of named spencers, unless otherwise noted. packet, 10c.

Igricola. Faint lavender and lilac. 1/2 oz., 15ес; oz., 25e.

Asta Ohn. One of the best lavender. Packet, 15e; $1 / 2$ oz., 30c.

Conntess spencer. Large, handsome rose pink. 1/2 oz., 20e; Oz., 3ic.

Dobbie's Blue Picotec. White, violet blue edge. $1 / 2$ oz., 20e; oz., 35c.

Fifrida Pearson. Large pale pink, one of the best. $1 / 2$ oz., 25e; 1 oz., 45.

Fitta Dyke. Fine white. $1 / 2$ oz., asc; oz., $45 c$.

Firey Cross. Intense orange scarlet $1 / 2$ oz., 25e; 1 oz., $45 \mathrm{c}$.

George Ilerbert. Rose Carmine. 1 oz., z0e: Oz., 35e.

Helen Lewis. Orange pink. $1 / 2$ oz., 20e oz., 35e.

Henrietta. Cream pink, very frilled. Packet, 15e; 1/2 oz., 30e; oz., 50..

Hereules. Pale rose pink, giant flowers. Packet, 15e; $1 / 2$ oz.. 30e; oz., 50c.

Illuminator. Salmon orange, overlaid cerise pink. $1 / 2$ oz., 25e; 1 oz., 45c.

Jean Ireland. Cream colored edged with pink. Packet only 10e.

ling Edward VII. The best pure red Spencer. 1/2 oz., 20e; oz., 35e.

ling White. Gigantic flowers, pure white. Packet, 15e; $1 / 2$ oz., 30e.

King Manoel. Giant chocolate maroon. $1 / 2$ Oz., 25e; Oz., 45e.

King Mauve. Largest waved mauve. Packet only 15e.

Iady Evelyn Eyre. Blush pink, white ground. $1 / 2$ oz., 25e; oz., 45e.

Lord Nelson. Navy blue, large flower. $1 / 2$ oz., 20e; oz., 35e.

Marmaret Atlee. Rosy salmon on buff ground. $1 / 2$ Oz., 25e; oz, 45c.

Mrs. Cuthluertson. Standard rose pink, wings pinkish white. Packet only 15e. Othello. Deep maroon. $1 / 2$ oz., 20c; oz., 35c.

R. F. Felton. The best lavender. Packet only 15e.

The President. Glowing scarlet self. Packet only 15c.

Wedgewood. Lovely self blue, light. $1 / 2$ Oz., 25e; oz., 45e.

"Exhibtion" Collection No. 351-One packet each of 25 varieties Spencer Sweet Peas for \$2.50. 


\section{SIVETT PEA (Continued)}

\section{$S$ W E T T P E M I X T U R S BEST GIRANDIFLORA VARIETIES, MIXED}

This is our choicest mixture of Sweet Peas and cannot be surpassed in variety or richness of color or size and substance of bloom. We make it ourselves and include in it not only the 10 varieties described above-a proved list of standard sorts, the very best in cultivation today-but a number of other named varieties and also a large percentage of the popular new wavy Spencer and Unwin types, thus making it thoroughly up to date. Packet of 70 seeds, te; oz., 15e; 1/4 1b., $45 \mathrm{c}$.

\section{GIANT CALIFORNIA SWEET PEAS, MIXTD}

A very choice mixture of only largefiowering types containing a large proportion of light colors with enough dark for a contrast. This includes also what I have left over from my choice named varieties. Every one knows that Sweet Pea seed retains its vitality for several years, so this is practically as good as if all were fresh seed. A packet, 100 seeds, 5e; oz., 10c; 1/4 lb., iøe; 1 b., \$1.00.

\section{CIRISTMAS OR WINTER FLOVIER- ING GRANDIFLORA}

Earliest flowering sorts, blooming in about twelve weeks from sowing, called "Christmas" Sweet Peas because used by florists for forcing in winter, but they are used more for out-door early spring planting.

Mixture. Made up of all the very best sorts for the critical grower. Price, packet, 50 seeds, 5c; 1/2 oz., 15c; oz., 25e.

\section{Special Mixed Spencers}

Made especially from the 25 varieties listed and other select sorts which, owing to short crop, we did not receive in quantities large enough to list separately. A high grade mixture sure to please. Price, packet, 75 seeds, 10e; $1 / 2$ Oz., 2Ge; oz., 35e; $1 / 4$ ib., $\$ 1.00$.

Spencer Hybrids. A splendid mixture of late introductions of the ruffled type, together with the best sorts from the trial grounds of one of our best growers. Price, packet, 8c; $1 / 2$ oz., 15e; oz., 25e; $1 / 4$ lb., S5c.

\section{TEN WEEIKS STOCKS}

Price, any packet, 5c.

Nwarf Carly Stocks Mixed. Large flowering, brilliant shades and among the earliest to bloom. Packet, 75 seeds. Dresien Perpetual (Cut, and Come Again), Rose. Best for cut.

Special Mixed. A mixture of all the best types and colors.

\section{'TRITONA, Reil Iot Poker Plant} The FLAMETLOWER. Fine for bedding or for the conservatory. A plant with gorgeous scarlet spikes, rivalling the Canna in brilliancy and the Gladiolus as a cut flower. They bloom from June until November, and are hardy, with protection, in most sections. New mixed hybrids. Packet, 40 seeds, Sc.

\section{MATMOTH VERBENA}

Price of each, per packet, 100 seeds, se; any 6 packets, 25e; 1/8 oz., 25c.

Anrieula-Flowered. Large fiowers with distinct white eyes in the center of each floret.

Pink. Fine pink shades.

Italian Striped. Various colors striped on white ground.

Purple. Deep rich purple.

Scarlet Defiance. Beautiful scarlet.

White. Pure white, extra large.

Fordhook Mammoth Mixed. A splendid mixture, with exceptionally large flower trusses, including all our named varieties, also best strains of several prominent growers. As fine as any of the highest-priced inixtures.

\section{"HIT OR MISS" FLOTVER GARDEN}

This is made up of what I have left over of last year's seeds that upon testing were found to germinate, together with a large quantity of flesh seed. A customer says: "The Hit or Miss' package is not correctly named, for I am sure it never misses something worth while. It is real fun watching to see what will come. and I often get pleasant surprises." Sift out the fine seed so that it may be planted under different conditions from the coarser seed. Large packet, 4c; oz., 10c.

\section{PEONY}

It is interesting to grow Peonies from seed, and one often gets new and valuable varieties. They do not bloom until the second or third year, but once established they pay for the long waiting. Sow seed in the fall. Packet, 20 seeds, 10c; $1 / 4$ oz., soc.

oféther A. Fvenimg Primrose Our patch of Oenothera was as showy a thing as we had in our garden, the large saucer-shaped flowers opening towards evening, emitting a delightful perfume. This is a mixture of several annual sorts, including the large yellow, or true evening primirose. 1 to 2 feet. Packet, 250 seeds, 5e. 


\section{GIANT PICOTEE ZINNIA}

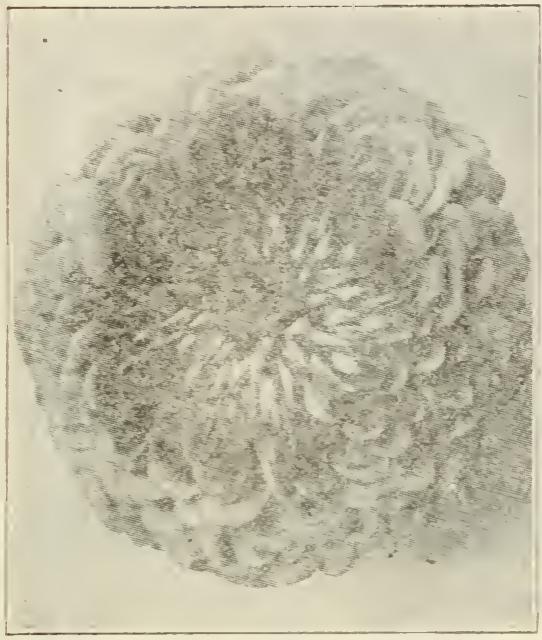

\section{ZIXNIA}

\section{Dahlia Flowered Zinnia}

These flowers have a very marked distinction from the ordinary giant flowered class, being a true Dahlia flowered type, and when plucked from the bush and placed by Dahlias it is difficult to distinguish one rrom the other. Te offer this in mixture in wide range of colors, ircluding Golden Iellow, Burnt Orange, Old Rose. Mauve, Cerise, beautiful shades of Pink and bi-color shades. Packet, 1úc.

\section{ZINNIA, DOLBLE GIAT, BLTTERCLP} This is a great improrement on any yellow of the giant class, being of a rich buttercup shade of yellow, and holds its color until the flowers commence to fade, when it changes to a deep cream color. Packet, 15e.

\section{GIANT VICTORY QUILLED ZINNIA}

The petals are quilled and twisted with a pin wheel effect in the center. The outside of the petals are of a coppergolden color and the under side shades of rose and illac. Packet, 15e.

\section{GIANT PICOTEE ZINNIA}

A remarkable new and distinct class with beautiful double flowers in shades of orange, flesh, lemon, pink and cerise, each petal being distinctly tipped with rarious shades of dark. resembling the Picotee Carnations-most attractive and pleasing. All colors mixed. Packet, 15 seeds, Sc.

\section{Golden Pheasant}

Vovelty.-A variety of the above, having flowers of a deep orange with maroon tips. Packet, $\mathbf{x} 5 \mathbf{c}$.

\section{ZITII. EPECIIL MIXED}

$A$ splendid mixture of all the large flowering varieties listed, including the Dahlia Flowered. Picotee, Buttercup and Quilled. Packet, Se: 2 for 15e.

\section{LARGE FLOWERING ZINNIA}

Zinnias in this section belong to the half dwarf class, having reference to size of plants, not to blossoms, as all are large flowering; more used for bedding timan any other class. All Zimnias are of rank growth, however, and one cannot get largest flowers from crowded plants. $11_{2}$ to 2 feet. Packet, 60 seeds.

Burnt orange. Bronze art shades, for which there is now quite a rage.

Bright Scarlet.

Jacqueminot. A dark velvety, geranium red, rivaling the Geranium for bedding.

Pink. Salmon-rose and flesh-pink.

Snowball. A very double white.

lellow. Lovely canary and other yel$10 \pi \mathrm{s}$.

Black Prince. Míaroon.

Improved Half Dwarf Mixed. Mixed or separate colors. Packet, 5e.

collection. One full packet each of $\overline{7}$ colors, 25e.

\section{NEW YIMUOTH ZINYIA}

The Largest and Best. A showy strain of Giant Zinnias, unsurpassed where somewhat tall, gaudy effects are desired. With proper conditions the flow$\in r s$ are of gigantic size and perfect form, in the most brilliant and best Zinnia colors. Should be 18 to 24 inches apart. Height, 21 ' to 3 feet. Packet, 30 seeds, 5e; 1/4 oz., zoe.

\section{MEXICAN ZINNIA}

Flowers are single, semi-double and double, size of a large daisy, in orange and bronzy yellow shades, resembling Dwarf Marigold. Very artistic for cutting and highly effective as an edging plant. 1 foot. Packet, 50 seeds, 5c.

\section{RED RIDING HOOD ZINNIA}

A little gem, covered throughout the season with small, intensely scarlet, very double flowers; highly effective for bedding. 1 foot. Pkt., 50 seeds, כe.

\section{LILIPCT ZINNIA}

Finest mixed double. 12 inches. The plants form handsome little bushes: flowers very double, about the size of an English Daisy. Bloom all sumner until killed by frost. Packet, 5c.

\section{CIRLED ATD CRESTED}

Double rixed. The flowers are large, the petals being $t w i s t e d$ and curved irito most graceful forms. Mlixture of all colors characteristic of the Zinnia. Packet, 5c. 


\section{SEEDS FOR THE PERENNIAL BORDER}

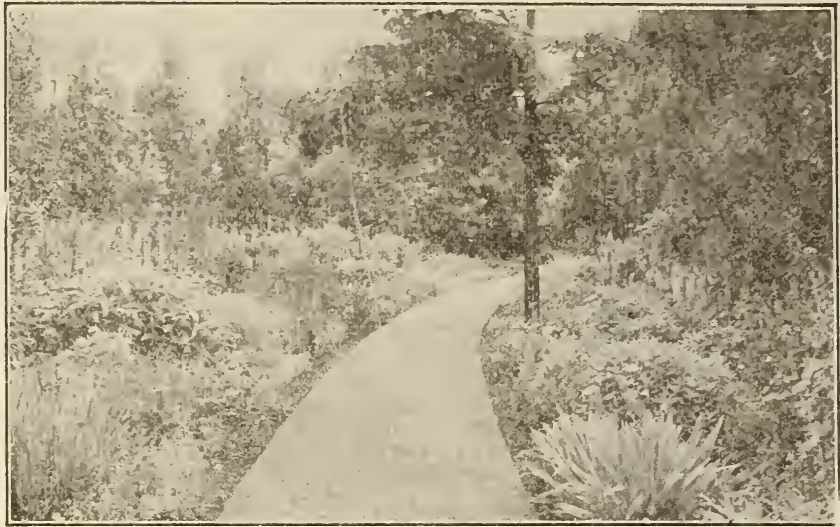

A Perennial Border

Price, each, per packet, $6 c$.

Botanical Name Common Name Period

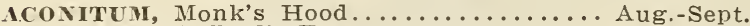
ADONIS Flos, Bird's-Eye....................... ALISSUM SAXATLLE, Basket of Gold....... May-June AGROSTEMMA CORONARI, Mullein Pink.. June-Sept. ANCHUSA CAPENSIS, Cape Forget-Me-Not.. June-Sept. A NCHUSI DROPMORE, Cape Forget-Me-Not. June-Sept. ANEMONE CORONARIA, St. Brigid's Poppy.. Aug.-Nov. BOCCONIA JAPONICA, Plume Poppy....... July-Aug. CAMPA NULA CARPATICA, Harebell....... June-Aug. COREOPSIS IANCEOLATA, California Sun-

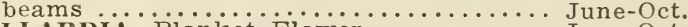
GAILLAIR DIA, Blanket Flower............ June-Oct. HEUCHERA, Coral Bells................ July-Aug. IBERIS GIBRALTRICA, Hardy Candytuft... April-May JAPANESE IRIS, Flowering Flag......... June

LUNAIRA BIENNIS, Honesty............. July-Aug. IUPINUS POLYPHYLLUS, Lupine................ LICHNIS HAAGEANA, Malcese Cross....... May-June MALV. MOSCHATA, Musk Mallow......... July-Aug. PHYSALIS FRANCHETTI, Chinese Lantern

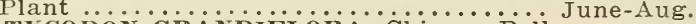
PLATYCODON GRANDifLoRA, Chinese Bell

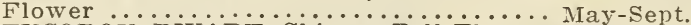
I'LATYCODON, DWARF, Chinese Bell Flower. May-Sept. VALERIANA, Garden Heliotrope..........June-July
PERFNNIAL BORDER in this connection means a large bed, often of irregular outline, bordering on, or b a c king u p against, a house, fence, shrubbery or trees, with low plants at the edge, $\quad \mathrm{gr}$ a d ing b a c k to tallest ones at the back. When once established. with proper selection, it will show bloom from early spring to late frosts. The following list includes the most popular sorts, aside from those described in regula $r$ alphabetical order.

Color

Blue or Mixed

Crimson

Yellow

Crimson

Blue

Blue

Mixed

Creamy White

Blue

Yellow

Yellow and Orange $2 \mathrm{ft}$. Mixed Reds $1 \mathrm{ft}$.

Lilac

Mixed

Purple

Mixed

Mixed

Pink and White

12 in.

$2-3 \mathrm{ft}$.

$2 \mathrm{ft}$.

$2-3 \mathrm{ft}$.

$1 \mathrm{ft}$.

$2 \mathrm{ft}$.

Scarlet Fruit

$2 \mathrm{ft}$.

Blue and White

Blue and White Mixed
$2-3 \mathrm{ft}$.

12 in.

$2-3 \mathrm{ft}$.

\section{MISCELLA NEOUS}

\section{PERENNIAL MITURES}

Price, each, per pkt., 10e; the 2 for 15e. This popular offer of mixed perennial seeds affords opportunity to try many varieties at small outlay. The two packets contain practically all the perennials we list. For planting instructions see page 8 of our "Culture of Flowers," which is free if asked for with an order for flower seeds of $25 \mathrm{c}$ or over.
Perennials, Mixed No. 1. This packet contains the first 15 varieties named above, and ten others described elsewhere.

Perennials, Mixed No. 2. This packet contains the last 15 varieties named above, also ten others not included in No. 1.

Old Perenuials (last year's seed). oz., 15e. 


\section{FLOWER AND VEGETABLE NOVELETIES}

\section{BLUE LACE FLOWER}

Didiscus Coeruleus. This Australian annual is worth a place in any garden for the rarity of its color and the delicacy of its bloom, the color being an azure blue and the cluster of tiny flowers arranged in a flat topped circle from one and a half to two inches in diameter is a beautiful subject for bouquets, a few of the lacy clusters with a little greenery giving a unique and beautiful efiect. Pkt., 10c.

\section{New Standard Spencer Sweet Peas}

Alexander Malcom. Glowing scarlet cerise. Pkt., 15c.

Market Pink. Rich pink, base of both standards and wings are cream. Pkt., 25c.

Hawlmark Pink. The richest colored Sweet Pea ever seen; rich, bright rose pink, deeply flushed and shaded salmon. This is the finest Sweet Pea introduced for several years. Pkt., 25c.

\section{CALENDULA, DANIA}

A desirable novelty of recent introduction, and should be tried by every flower grower. Compact, round bushes, flowers deep orange-red and of unusual size. Plants grow so evenly that they can successfully be used for edgings or borders. Packet, sc.

\section{GODETIA, CATTLEYA}

This splendid new Godetia is appropriately named after the beautiful orchid, of which it represents very faithfully the peculiar, pleasing lilac color. Fine border plant. Try it. Packet, 10c.

\section{KITCHENETTE SQUASH}

Accurately described this is a miniature Hubbard Squash, specially adapted for the small family, hence the name kitchenette. Hard shelled, color dark bronze, flesh bright orange-yellow, fine grained, thick, dry and richly flavored. Pkt., 15c; 5 for 50c.

\section{MLSKMELON-GOLDEN OSAGE}

New. Oval-shaped, outer skin greenish-yellow, flesh salmon yellow, thick and deliciously sweet. Recommended for both kitchen, garden or market Pkt., 15e; 5 for 50c.

\section{EARLY FLOWERING SPENCER} SWEET PEAS

Early Inethyt. Royal purple. Pkt., 25e.

\section{SWEET WILLIAY}

New Innual. A cross between the Chinese Pink and Sweet TVilliam, having the free and continuous blooming qualities of the former and hardiness of the latter. They bloom the first season. Mixed. Price, packet, 5c.

\section{LILLIPUT POPPY}

Papaver Rhoeas, Pumilum. A new annual single Shirley poppy. Plants 12 to 14 inches only, forming small, close bushes. Remarkably free blooming single plants producing 60 to 120 flowers $1 \frac{1}{2}$ to 2 inches in diameter; color, light or dark rose. A bed, group or border of these charming little plants offers a surprisingly beautiful sight. Fresh blooms appear daily and the blooming period lasts all over the summer months. Seed must be sown in the open ground in spring. Pkt., 10c.

\section{LIWN GRASS SEED}

Our lawn grass mixture is the one especially recommended by the U. S. Department of Agriculture and is the very best that can be made. If directions are followed, it will give a soft, close sod of uniform texture and rich emerald green. Allow $1 \mathrm{lb}$. for 350 to 400 square feet; 5 bushels per acre.

Directions: To secure the best lawn, the soil should be well drained and deeply plowed. and fertilized with well rotted manure or some good commercial fertilizer. Harrow or rake it as fine as possible and roll before the seed is sown. Sow as early in the spring as possible, or in september for fall sowing. For further instructions see Culture of Flowers, page 31 (free if asked for with an order of flower seed of 25e or over).

Lawn Grass, Highest Grade, 1/2 1b., 35e, postpaid; 1 lb., 60c, postpaid; 3 lbs., \$1.65, postpaid. One 1b. equals from $11 / 2$ to $13 / 4$ qts.

shady Place Lawn Grass. A mixture especially adapted for sowing under trees and other shady places. $1 / 2$ lb., 40c: 1 lb., 75c; 3 lbs., \$1.95, all postpaid.

Fientucky Blue Grass, High Grade. 1/2 1b., 40c: 1 lb., 75c; 3 lbs., \$1.95, all postpaid.

White clover, Sterling Grade. The past few seasons have been so unfavorable for the clover crop that stock is scarce and prices greatiy increased. 1 oz., 8c; $1 / 1$ lb., 25c; 1 lb., S5̌c, all postpaid.

\section{CORY-BANTAY EVERGREEN}

A cross between Golden Bantam and Sto well's Evergreen, thin hulled and fine quality. Ears 8 inches long, 12 rowed, matures 10 days to 2 weeks later than Golden Bantam. Grain broad, deep and a rich golden yellow. Large packet, $15 \mathrm{c}$; 1b., 40c; postpaid. 


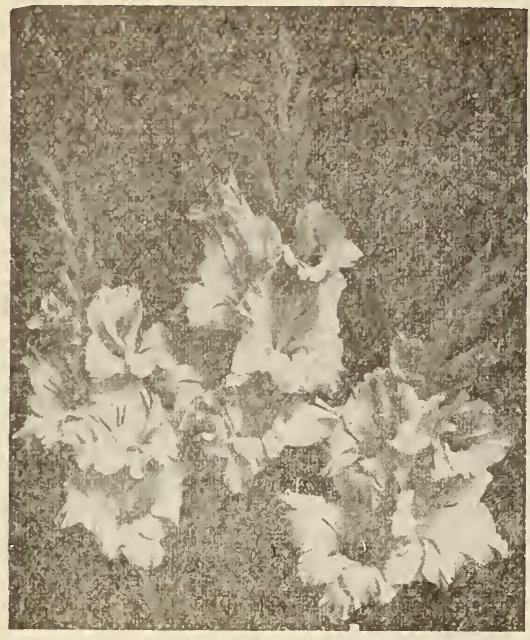

\section{GLADIOLUS}

The most popular of all summer flowering bulbs, of easy culture and almost free from disease and insects. Effective for planting with other flowers and an excellent cut flower. Plant six to eight inches apart and four inches deep.

\section{SUPERB GLADIOLUS OF RECENT INTRODUCTION}

Evelrn IKirkland. Color beautiful shade of rosy pink, darker at the edges, fading to shell pink in the center, with brilliant scarlet blotches on lower petals; the entire flower showing a glistening lustre. Very tall spike. Extra fine form and color. Each, 20c; dozen, $\$ 2.00$.

Hereda. Something entirely different but another good one. Blooms of immense size on tall straight spikes. Massive in every way. Color pure mauve, glistening and clear, with deeper markings in throat. A very attractive color. Each, 20c; dozen, \$2.00.

IRertrex. Color white with lilac throat; size and form of America. An excellent cut flower variety. Each, 15e; dozen, \$1.50.

Mrs. Frank Pendleton. Lovely salmon pink with brilliant deep red blotches on lower petals. A color combination rivaling the orchid in richness. Each, 1.ie; dozen, \$1.50.

Collection No. 401. One each of above 4 sorts, 60c.

Collection No. 402. Three each of above 4 sorts, $\$ 1.75$.
SIX SPLENUID SORTS THAT SHOULD

BE IN EVERY FLOWER GARDEN

War. Deep blood red, shaded crimson black. Very tall and conspicuous. Each, 26e; dozen, \$2.00.

Peace. Beautiful large white blooms on tall straight stems. Each, 10c; 1 dozen, \$1.00.

America. Beautiful soft flesh-pink, orchid-like in coloring and texture. Each, Ge; dozen, 60e.

Blue King. A really fine blue gladiolus, effective in conjunction with the yellow scrts. Each, 10e; 1 dozen, \$1.00.

1910 Rose. Tall rose pink. Fach, 12c; dozen, \$1.25.

Niagara. Cream, blending to canary yellow. Each, 10c; dozen, \$1.00.

Collection No. 403. One each of above 6 sorts, 60c.

Collection No. 404. Three each of above 6 sorts, \$1.65.

\section{TEN STANDARD GLADIOLUS}

Mrs. Watt. Clear wine red of the most pleasing color. Each, 12e; dozen, \$1.25. Halley. Very early salmon pink. Each, 7e; dozen, zic.

Mrs. Francis King. Brilliant vermillion scarlet. Most popular and effective variety for all occasions. Each, Ge; dozen, G0e; 100, \$в.Ј0.

Ida Van. Red, darker than Mrs. Francis King, large and one of the best reds. Each, 10c; dozen, \$1.00.

Panama. Rich rose pink; a favorite wherever ligh grade varieties are desired. Each, 10c; dozen, \$1.00.

Meadowrale. TVhite with line of pink on lower petals. Each, 12c; dozen, \$1.25.

Pride of Gioshen. Fuffled, giant salmon. Each, 15e; dozen, \$1.50.

Prineipine. Carmine red with white throat, very attractive. Each, 10e; dozen, \$1.00.

Schwaben. Pure canary yellow, shading to a soft sulphur yellow. Strong spike and sturdy plant. Each, 12e; dozen, \$1.25.

Blue Hybrid Seedlings. Best of blue shades. Each, 7e: dozen, 75c.

Collection No, 40.. One each of above 10 sorts, 95e, postpaid.

\section{GLADYOTUS MIXTURES}

Our Very Best Mixture. Made up of choice named rarieties, including lavender and blue shades, yellow, pink, red and crimson, white and all conceivable colors and combinations of colors. Price, 3 for 15e: dozen. 50c; 100 , \$3.50; 25 at 100 rate. Postpaid.

very Good Mixed. A splendid lowpriced mixture of good standard varities, 3 for 12e; dozen, 40e; 100,\$3.00; 25 at 100 rate. Postpaid. 


\section{ORNAMENTAL AND FLOWERING SHRUBS}

All hardy, popular varieties. Price, except Flowering Almond, Flowering Plum, and Hydrangeas, strong 2 year stock, 35e each; any 3 for $\$ 1.00$, postpaid.

Can furnish any of the varieties listed at 35c; in a stronger size at $50 \mathrm{c}$ each, by express, not prepaid.

Complete list and prices of shrubs, trees and nursery stock mailed on request.

Flewering Almond, Double White or Pink. Very early. 4 feet. In 2-year stock only. Price, each, 75c.

Barberry, Japanese, or Thunberg's. A dwarf variety. Nothing better for a low hedge. Especially showy in the iall when the foliage turns to brilliant reds. 2 to 3 feet.

Dogwood. Variegated-leaved red. Fine silvery and green foliage. 4 feet.

Euonymus Americanus. Strawberry Shrub or Burning Bush. Reddish brown flowers, with strawberry odor. followed by red fruits, which hang on all winter. Its fall foliage is intensely colored. 6 feet.

Cut-Leaf Elder. Perfectly hardy and highly ornamental. In passing through Wisconsin, its effectire use is seen in many of the station grounds. $\delta$ feet

Honeysuckle, Tartarian. White pink or red. One of the early bloomers. 6 to 8 feet.

Hardy Hydrangea, Everblooming Snowball. Bears immense pure wnite pan1cles, resembling those of the House Hydrangea, in bloom from June until September. Each, 50c.

Hardy Hydrangea, Paniculata Grandiflora. One of the hardiest shrubs, and not excelled by any other. 4 to 6 feet. Each. 50c.

Double Flowering Plum (Prunis Triloba). Very beautiful; flowers large. double, rosy pink. 8 feet. In 2 -year stock only, 75c.

Spirea, Anthony Waterer. Blooms all summer in clusters of rose-colored flowers. 2 feet.

Spirea, Golden. A fine golden foliage shrub. Does best in sunny places. 6 to 8 feet.

Spirea Sorbifolia. Mountain Ash leaved Spirea. Beautiful foliage and large heads of white bloom. Splendid landscape variety.

Spirea, Thunberg's. The earliest to bloom. The leaves are small and abundant, making it a fine hedge plant. 3 to 4 feet.
Spirea Van Houttei, or Bridal Wreath. No hardier, handsomer or better shrub. 5 feet.

Spirea Billardi, pink or white. Flowers in terminal rose colored or white spikes from July until frost. $1 \frac{1 / 2}{2}$ to 2 feet.

Syringia, Avalanche. Flowers are very sweet and produced so profusely that their weight bends the branches almost to the ground, the bush having the efiect of being covered with newlyfallen snow. 5 feet.

Weigelia Rosea. Rosy-pink flowers; very popular. 4 feet.

Snowball (Viburnum Sterilis). The well-known common Snowball. 8 to 10 feet.

\section{LILACS}

Common White or Purple. 1 to 2 feet, 35e each; 2 to 3 feet, 50c each.

Persian White or Purple. 1 to 2 feet, 50 e each; 2 to 3 feet, 75 e each.

The Newer sorts. The ordinary lilac suckers badly. but the newer sorts are mostly grafted on ash roots and do not sucker. With 25 distinct varieties, single and double, to choose from we will supply these new varieties as follows: 1 to 2 feet (your choice of color), 50e each; 2 to 3 feet (your choice of color), 75e each

EVERBEARING STRAWBERRIES Postpaid, 75e per 25; $\$ 2.50$ per 100. By express, \$2.25 per 100 .

Progressive. Tery productive.

Superb. The largest.

Dulnth (Minn. 1017). Thrifty and of good quality.

\section{STANDARD STRAWBERRIES}

Postpaid, 40c per 25; \$1.25 per 100.

By express, \$1.00 per 100 .

Bederwood. Early.

Brandywine. The latest.

Cncle Jim. Productive, large.

Senator Dunlap. The old favorite.

Iinnesota 3. New early berry of merit. Gibson. Large, firm, fine.

Pride of Michigan. Large, fine berry.

$$
\text { RHUBARB OR PIE PLANT }
$$

20c each; \$1.50 per 10;\$10.00 per 100 .

\section{ASPARAGUS}

2 year roots. 5e each; 40 e per $10 ; \$ \mathbf{\$ 2 0 0}$ per $100 ; \$ 15.00$ per 1,000 .

\section{HORSE RADISH}

10c each; 75e per $10 ; \$ 5.00$ per 100 .

\section{CANNAS}

(Dormant roots.) Choice Mixed, 20e each; \$1.50 per $10 ; \$ 10.00$ per 100 . Green or bronze foliage, 25c each; \$2.00 per 10 ; $\$ 15.00$ per 100 . 


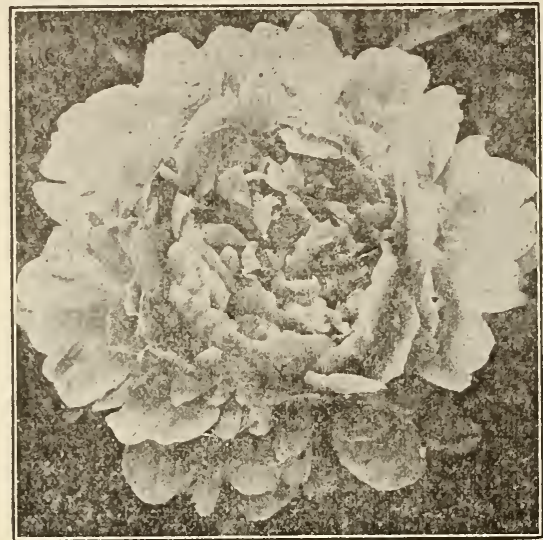

\section{PEONIES}

The most popular perennial for the garden. Being our home flower, perfectly hardy, one planting will do for a life-time and requires but little cultivation.

Spring orders should be in by the 1st of May, shipments made direct from the nursery.

Postpaid at prices listed.

Ask for our Catalog of Plants, Bulbs and Shrubs for Fall planting.

Collection No. 420. Three Peonies (our selection), \$1.00, postpaid. Single Peonies in White, Red or Pink Shaded, 50c each.

\section{WHITE PEONIES}

Festiva Maxima. Best early, fragrant, white with crimson markings in center. Each, 50c.

Madam d'Verneville. An extra fine, free bloomer with blushed pink center. Each, 75e.

Golden Harvest. Pink outside or guard petals and bright yellow center. Best yellow peony. Each, \$1.00.

Courrone d'or (Crown of Gold). Beautiful white with ring of golden stamens. Each, 75c.

\section{RED PEONIES}

Karl Rosenfield. The best late, dark red; large, strong, ideal. Each, \$3.00.

Louis Van Moutii. Early, bright crimson. Very free bloomer. Each, 50c.

Count Paris. Large, strong, rosy red. Each, 50e.

Felix Crousse. Choice, brilliant red. Each, 75c.

Andre Laures (Fragrans). Late, rosy red. Each, 50c.

Lamartine. Large, bright carmine. Each, 75c.

\section{PINK PEONIES}

Achillea. Early flesh pink, free bloomer. Each, j0e.

Edulis superba. Early, free, bright pink. Each, 50c.

Victoria Tricolor. Bright pink, free bloomer. Each, 50c.

La Tulip. A beautiful, late strong grower; outer guards and center striped with crimson. Each, \$1.00.

Etta. Choice, late flesh pink. Each, $\$ 2.00$.

Arthemise. Large bright pink.

Canary. Creamy white.

De Candolle. Choice red.

Duke of Wellington. Fragrant, white. Eclantante. Very dark red.

Francois Ortegat. Rich crimson.

Grandiflora Rubra. Late, tall dark red. Modesty. Rosy pink.

M. Krelage. Large dark red.

Madam Le Bow. Fragrant cherry.

Price, each, 50c; the 10 for \$4.50.

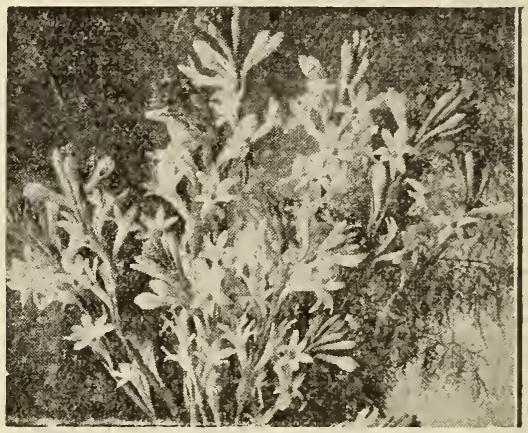

THE NEW MEXICAN TUBEROSE

A beautful variety, with pure white, single flowers of delightful fragrance. Each bulb sends up 5 to 15 flowers, showing a mass of white until cut down by frosts. Do not set out until settled warm weather. Hardy in the south and south central states. In the north treat same as Gladiolus bulbs. Price, 10c each; 3 for 25e; 12 for 90c. postpaid. 
HARDY PLANTS FOR PERENNIAL BORDER

Plants for either spring or fall delivery. For spring delivery get orders in, if possible, by May 1 . No orders filled after about May 10, All sent

prepaid either by mail or express.

Don't buy one plant of a kind and expect it to make much of a showing. Get at least six (at dozen rate) and group them together. In making selections, where different colors are given, be sure to state color wanted.

25 c each; \$2.00 per $10 ; \$ 15.00$ per 100 .

Collection No. 430. 30 sorts (our selection) for \$5.00.

Collection No. 431. 7 sorts (our selection) for $\$ 1.00$, postpaid.

Achillea Pearl

Coreopsis

Delphinium

Funkia, Variegated

Funkia, Grandiflora

Lily of the Valley

Platycodon

Sedum Veronica

Hardy Asters

Hardy Marguerite

Hardy Pinks

Hardy Ferns

Spec: Roseum Lily. 35c each.

Oriental Poppy. 35e each.

Anratum Lily. 35c each.

Bleeding Heart (common and everblooming), 50c each.

Butterfly Bush. 35e each; \$3.00 per 10.

lellow Lady slipper. 35 each.

white Lady slipper. 50c each.

\section{IRIS}

7 Iris (our selection), \$1.00, postpaid. Any 10 20c Iris for $\$ \mathbf{1 . 5 0}$, postpaid.

Any 10 25e Iris for $\mathbf{\$ 2 . 0 0}$, postpaid.

Siberian Blue. Late, rich violet. Each, 20c.

Siberian White. Dainty, pure white. Each, 20c.

Siberian snow Queen. Large, ivory white. Each, 25c.

Aurea. Strong growing, late, pure yellow. Each, 25c.

Augustine. Fellow, veined reddish brown. Each, 20c.

Blue Bird. Early, indigo blue. Each, 20 .

Bronze. Light yellow tinged with red. Each, 20c.

Celeste. Fragrant lavender. Each, 20c.

Donna Maria. Lavender, purple falls. Each, 20c.

Delicata. Fragrant, light yellow veined purple. Each, 20c.

Honorabilis. Orange, lower petals maroon. Each, 20c.

Her Majesty. Large, rosy red, veined maroon. Each, 25c.

L'Avenir. Choice, light blue. Each, 20c.

Mrs. Darwin. Pure white, veined lavender. Each, 25c.

Pyrethrum Hybrids
Tiger Lily
Campanula
Columbine
Gypsophila
Hibiscus
Lychnis
Lupine
Spirea Japonica
Elegans Lily

Madam Chereau. Tall, late, white with light blue edging. Each, 25c.

othello or Sapples. Velvety purple. Each, 20c.

Palcata. Lavender veined red. Each, 20c.

Pumilla. Dwarf type; earliest to bloom, light blue and dark blue sorts. Each, 20c.

Queen of Gypsies. Rosy bronze, tinged with blue. Each, 25c.

Rhine Nixe. Large, late, white, violet falls. Each, 25c.

silver King. Large, fine, nearly, lavender. Each, 25c.

\section{IRIS. AND PHLOX}

Unnamed or Mixed, 20c each; \$1.50 per $10 ; \$ 12.50$ per 100 . Named or any color, 25c each; \$2.00 per 10;\$15.00 per 100 .

Special. 7 Iris or 5 Phlox, postpaid, $\$ 1.00$.

\section{HEMEROCALLIS OR DAY LILY}

25c each; \$2.00 per 10;\$15.00 per 100 .

Graminea. Earliest dwarf yellow.

Flava or Lemon Lily.

Thunberg. Late, tall yellow.

Gold Dust. Dwarf, bronze.

Dumorteri. Dwarf, fragrant orange.

Kwanso. Double, tall orange.

Special. 5 Hardy Lilies (our selection), postpaid, $\$ \mathbf{1 1 . 0 0}$. 


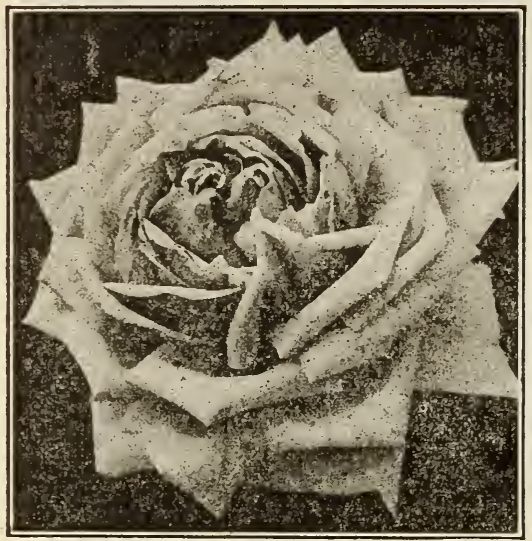

EVERBLOOMING ROSE

Columbia, 1 year, 35e; 2 years, 70 e

\section{ROSE AND MISCELLANEOUS PLANT DEPARTMENT}

Our Roses and other plants have attained a world-wide reputation for vigor, hardiness and blooming qualities. We send out only such plants as are young and thrifty and which will surely please.

We guarantee safe delivery.

Shipment. All plants forwarded from greenhouse day order is recelved, unless otherwise instructed. If plants are wanted shipped any special time, give definite date.

Postpaid. All plants sent postpaid (except where noted).

Please notify us if you don't receive plants witnin a reasonable time.

White Killarney. (S. H. W. P.) Pure white and free blooming. 1 year, each, 28c; 2 year, each, 75c.

Rena Robbins. (S. B. H. W. P.) Pure white with golden heart; unexcelled. 1. year, 30c; 2 year, 75c.

Radience. Pink American Beauty. (S. B. H. W. P.) A lovely rose pink color. sweet scented and free flowering. 1 year, each, 28c; 2 year, 75 .

Mrs. H. Winett. (S. B. H. W. P.) A bright crimson. Finest of red or crimson roses. Prized for fragrance. 1 year, 30c each; 2 year, 70c.
Francis Scott Key. (S. B. H. W. P.) In honor of the writer of the "Star Spangled Banner." A dazzling crimson globular rose of immense size. 1 year, 28c; 2 year, 75c.

Columbia. A perfect peach-blow pink which deepens as it opens. Long stiff stems, glossy foliage, and flowering freely during the whole season. Fragrant. 1 year, each, 35c; 2 year, 70c.

Perle Des Jardins. Color, cream-white: foliage, thick, dark, glossy red. 1 year, each, 28c; 2 year, 68c.

Kaisering Augusta Victoria. (S B. H W. P.) Pure white: continuous bloomer; nothing more fragrant. 1 year, 27 ; 2 year, 75c.

\section{COCHET BEDDING ROSES}

Crimson Cochet. Bright crimson flowers, large, fragrant and lasting. I year, each, 24c; 2 year, each, 68c.

White Maman Cochet. (S. B. H. W. P.) The best snow-white rose for open ground culture. 1 year, each, 22c; 2 year, each. 6sc.

Yellow Maman Cochet. (S. B. H. W. P.) The best hardy everblooming yellow rose. 1 year, each, 25c; 2 year, each, Foc.

Pink Maman Cochet. (S. B. H. W. P.) Perfectly double, superb flowers. Color, clear, rich pink, changing to silvery rose. 1 year, each, 24e; 2 year, each, 60c.

Red Maman Cochet. (S. B. H. W. P.) Flowers, long pointed; color, warm rose-crimson. 1 year, each, 20c; 2 year, each, 60c.

Collection No. 514. One each of thr above 5 Cochet Roses. 1 year, \$1.00; 2 year, \$3.00.

\section{POLYANTHA BEDDING BUSH ROSES}

Baby Ramblers, all summer blooming hardy with protection.

Jean D'Arc. Pure white, flowering trusses produce up to 100 blooms and buds. Long season of bloom.

Jessie. For bedding or pot culture. Cherry-crimson and do not fade.

Baby Rambler. Compact bushes about 2 feet, covered with clusters of rich crimson-red flowers through the whole season.

Baby Doll. An entirely new color. It is golden yellow, tipped with clear, bright cerise. Dwarf grower and a splendid bedder.

Price, each, 1 year, 25e; 2 year, 70c. Collection No. 516. 1 each of the above four Baby Ramblers. 1 year, 90c; 2 year, \$2.50.

Note: The following abbreviations used in the above descriptions denote:

(H. P.) - Hybrid Perpetuals.

(H. J. B.)-Hardy June Blooming.

(S. B. H. W. P.)-Summer Blooming Hardy with Protection. 


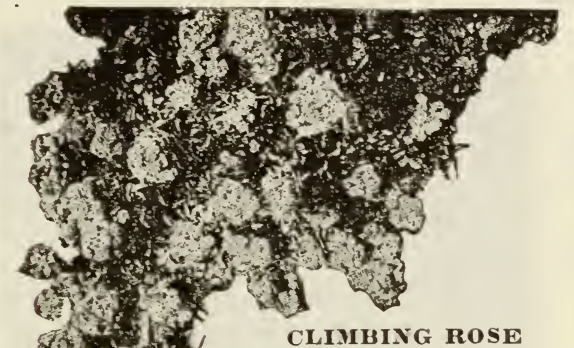

CLIMBING ROSE

Dorothy Perkins. 1 year, 25e;

H A R D Y J U N E CLIMBING ROSES

Climbing American B e a ut $\mathbf{y}$. H a r d $\mathbf{y}$, strong $\mathrm{grow}$ ing, making canes from 10 to 15 feet in a season. Rosy-crimson fl o w e r s, produced freely in June. 1 year, each, 30; 2 year, each, 75c.

Dorothy Perkins. The most graceful, free flowering and vigorous climbing rose; flowers produced in clusters, thousands on a single plant. Beautiful, fragrant shell-pink rose. I year, each, 25e 2 year,; each, 70c.

White Dorothy Perkins. A pure white sport of the Dorothy Perkins. Blooms at the same time. 1 year, each, 25e; 2 year, each, 65.c.

Shower of Gold. Deep golden-yellow and orange. 1 year, each, 25e; 2 year, each, 75e.

Dr. W. Van Fleet. The flowers, when open, measure over 4 inches in diameter, and are borne in profusion. Color, delicate shade of flesh pink, double and very fragrant. 1 year, each, 30c; 2 year, each, roc.

Christine Wright. (Pink Climb. American Beauty.) Double flowers, $31 / 2$ to 4 inches in diameter. A bright wild-rose pink. 1 year, 30c; 2 year, 75 c.

American Pillar. "Hardy as an Oak." Its mass of flaming-pink flowers, 3 to 5 inches in diameter fairly covers the bush. 1 year, 28c; 2 year, 70c.

Tausendschoen. (Thousand Beauties.) Colors run from rose through the shades of carmine, with white, yellow and other tints showing; strong grower, few thorns. 1 year, 27 e each; 2 year, 75e each.

Collection No. 518. 1 each of the above 8 Climbing Roses, 1 year, \$2.00; 2 year, 85.00 .

\section{HYBRID PERPETUAL OR JUNE ROSES}

Price, 1 year, each, 30c; 2 year, each, 75e.

Madame Masson. (H. J. B.) Crimson, symmetrically perfect and fragrant. Begins to bloom when plant is small and blooms over a long period.

Gloire De Lyonnaise. Salmon yellow. 1 year, each, 28c; 2 year, each, 75 e.

Clio. The Peony Rose. (H. J. B.) Flowers very large; color, flesh, shaded in center to pink. Hardy, vigorous grower and free bloomer.

General Jacquiminot. ( $H$. J. B.) Famous the world over as one of the most magnificent, hardy crimson roses ever produced.

Vick's Caprice. Large flowers; color, satin-pink, striped with carmine. It is beautiful in bud form. 1 year, each, 25c; 2 year, each, 70c.

Coquette Des Alpes. A flne formed, pure, large white rose; beautiful shellshaped petals.

Collection No. 510. 1 each of the above six 2 year roses for $\mathbf{\$ 3 . 7 5}$.

Collection No. 512. 1 each of the above six 1 year roses for \$1.25.

\section{HARDY JUNE ROSES (Continued)}

Madam Chas. Wood. Hardy in the north without protection. The flowers are large, perfectly double and of dazzling scarlet-crimson color.

Eugen Furst. Brilliant cherry red. Fine form and fragrant. Excellent cut flower. 1 year, each, 28c; 2 year, 75 c.

Madam Plantier. A white rose of exceptional beauty, withstands drought, therefore adapted for cemetery planting. 1 year, each, 25c; 2 year, each, 70c. Gloire De L'Exposition De Brussels. The black rose. One of the largest and best garden roses. Velvety crimson rose, with flrey center. 1 year, each, 30c; 2 year, each, 75c.

Black Prince. Awarded National Rose Society Gold Medal. Fine dark crimson and one of the most fragrant roses in cultivation. 1 year, each, 25e; 2 year, each, 70c.

Anna De Diesbach. Brilliant pink, long, pointed buds and large, fineformed flowers. 1 year, each, 28c; 2 year, each, 75c.

\section{CARNATIONS}

25e each; 3 for 72 .

Enchantress. Popular light pink.

Harlowarden. Dazzling crimson.

Rose-Pink Enchantress. The prize winner.

Matchless. Unexcelled white.

Gaiety. White, penciled red. Spicy fragrance.

victory. A scarlet necessity. 
BRILLIANT BEDDING SALVIAS

Price, each, 20c; dozen, \$2.00.

Salvia Splendens Bonfire. (Flowering Sage.) Flaming scarlet.

White Salvia. Identical with Splendens. Spotted Salvia. (Audubon.) Yellow blotched leaves; flowers bright scarlet. The Hyacinth Flowered Salvia. St. Louis. Flower spikes are longer and more double than Splendens.

\section{OLEANDERS}

Price, each, 25e; 5 for $\$ \mathbf{1 . 1 0}$.

Handsome specimens in tubs for veranda or yard. Can be wintered in the cellar.

Oleander Rosea. Double pink, an old favorite; fragrant.

oleander Lilian Henderson. Double white.

Oleander Rubra. Semi-double, watermelon red.

\section{DOUBLE GERANIUMS}

Price, 24c each; 3 for 65e; 6 for \$1.15. Alphonse Ricard. Very large, semidouble vermillion-scarlet flowers. Blooms freely all the season.

Beaute Poitevine. Best salmon pink; a great bloomer, always in great demand.

Bertha De Pressily. The only pure delicate pink Geranium that does not fade in summer.

Buchner. Pure snow white.

Jean Viaud. Immense semi-double flowers of clear rosy pink; white eye.

S. A. Nutt. Dark, rich velvety red. Used more for bedding than any other.

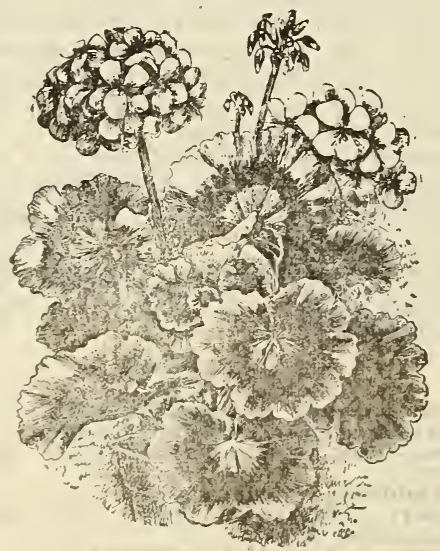

Salmon Geranium, Beaute Poitevina

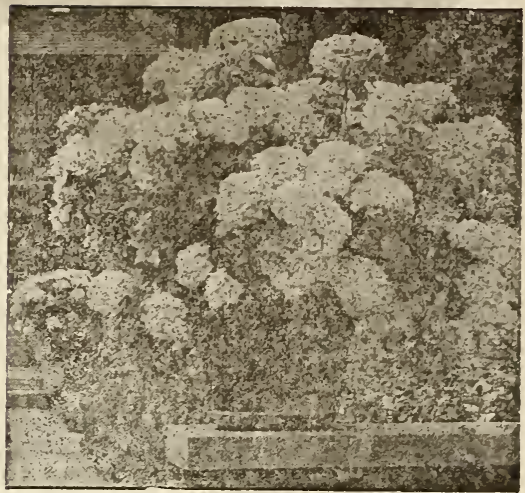

\section{PORCH HYDRANGEA La France, 30c}

\section{PORCH HYDRANGEAS}

\section{Summer Flowering}

Mad. Emile Mouillere. One of the finest. Large pure white, with carmine rose eye. Price, 30c.

Bouquet Rose. Large trusses of well formed flowers. Color, rose. Price, 30c.

La France. Beautiful fringed delicate rose. Price, 30c.

Monstrosa. Large flowering pink.

\section{CHRYSANTHEMUMS}

Price, 24c each; 3 for 70 c.

Black Hawk. Deep blood red.

L'Infant. Best white Ostrich Plumed Mum.

Chieftan. Largest pure pink.

Major Bonafion. A yellow 8 inches across.

Ivory. White; exquisite form and finish.

\section{HIBISCUS \\ Giant Flowering}

Price, each, 25e;

Aurentiaca. Beautiful double orange flowers.

Miniatus Semi-Plena. Bright vermillion-scarlet flowers.

Peachblow. One of the finest: flowers are double, of rich, charming, clear pink. New and beautiful shade.

\section{GLADIOLUS COLLECTION}

No. 390. 18 choice named sorts in mixture. Price, 75c, postpaid.

No. 391. 30 Trial Ground Mixed Gladiolus. Price, \$1.00, postpaid. 


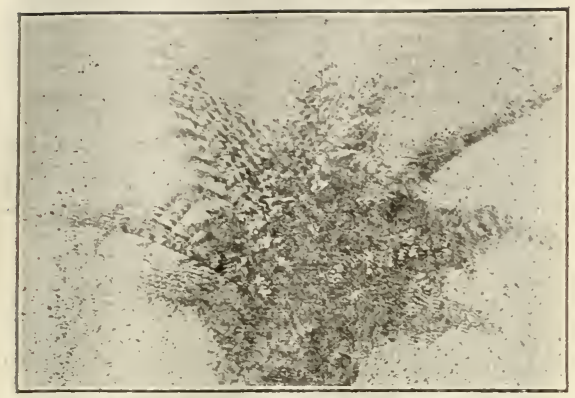

Ostrich Plume Fern, 30c-60c

DFCOR I TIVE FERNS

The Ideal Roosevelt. Fronds are broad and heavy, the divided pinnae or miniature fronds give the plant a light lacey effect. Tery pretty. Price, each, 30c; large plants, 60c. Postpaid.

The Gold Vedal Fern. Valuable on account of its easy culture. Fronds are broad and heavy. Very graceful. Price, each, 30c; large plants, 60e. Postpaid.

Whitmanii or Ostrich Plume Fern. The fronds are finely cut, giving a most graceful plumy effect. Thrives in the house. Price. each, 30c; large plants, 60c. Postpaid.

The Boston Fern. The most popular fern in cultivation.

"Teddy, Ir." A sprout of the Roosevelt fern, fronds shorter, slightly drooping, forming a shapely, graceful plant.

Lace Fern, Asparagus Plumosus. One of the most popular follage plants of the century. May be grown as a pot plant. a bushy form or climber. Price. each, 25c; large plants, 50c.

Feather Fern, Asparagus Sprengeri. Unsurpassed for window boxes or for hanging baskets. Price, each, 25e; large plants, 50c.

\section{SWEET-SCFNTED GERANIUMS}

Now extensively grown for their fragrant foliage; sometimes used among cut flowers which have no perfume of their own. Price, except where noted. 25e; 3 for $\mathbf{2 c}$.

Cut-I.eaf Rose. Richly scented rose. Balm. Excellent for bouquets. Lilaccolored flowers.

oak-Leaved. Leaves somewhat resemble those of the Oak; striking.

Jady Mary. Nutmeg scented; bright pink flowers. 27e each.

\section{MISCELL I NEOUS PLANTS}

Weeping Lantana. Blooms continually winter and summer. Lavender. Price, each, 25e; 3 for $7 \mathbf{2 c}$

Tritoma Phitserii. An improved variety of the popular Red Hot Poker plant. Large spikes of brilliant flame color. Price, each, 40c; 3 for $\$ 1.00$.

Wandering Jew. A variegated rapid growing vine, much used for hanging baskets and porch boxes. Price, each, 201: dozen, \$2.00.

Vinca, Variegated Perwinkle. Trailing vine admirably adapted for hanging baskets, vases and window boxes. Leaves variegated white and green. Price, each, strong plants, 40c; 3 for \$1.10: dozen, \$4.00: small each, 20c; 3 for 5ృc; dozen, \$2.00.

\section{SINSEVIFRA}

Snake Plant. A new decorative plant for the house or porch box. Its swordlike, striped leaves are very striking and give it its name of Snake Plant. No other plant so well endures the gas or dust of the living room, and it thrives under all sorts of neglect. Price, 25c; large plants, 75c.

\section{CI.EMATIS PANICULATA}

Considering its almost miraculous habit of growth, its pleasing white fowers, which appear in wonderful pr fusion in August and continue until late fall, its fragrance, this plant is the choicest and most satisfactory flowering vine we grow. Adapted for porches, trellises, etc. Hardy. 25c each; larger plants, 50c; field-grown plants, \$1.00.

For covering brick or stone walls, fences, etc. Foliage deep green, changing to bright crimson in fall. Hardy everywhere. Price, 25e; extra large plants, 60c.

\section{CHINESE CINNAMON VINE}

The most rapid grower we know of. The glossy heart-shaped leaves and clusters of white flowers make arbors and verandas bowers of beauty. Hardy. Price, 16c each; 3 for 45e.

\section{WEFPING I, NTANA}

Of drooping habit; blorms the year around, producing clusters of lavender flowers. Its use is unlimited. Price, nice plants. 25c each; 3 for $\mathbf{7 2 c}$

\section{FIRE CRACKER PLANT}

The plant is of slender, arching, drooping nabit, literally covered with brilliant coral-red buds and flowers. Adapted to hanging baskets, porch boxes, etc. 25c each; 3 for $\mathbf{6} 2$.

\section{NIGHT BLOOMING JASMINE}

Something to be appreciated; greenish white flowers of delightful fragrance, which is dispensed during the night only. 35e each; 3 for $\$ 1.00$. 


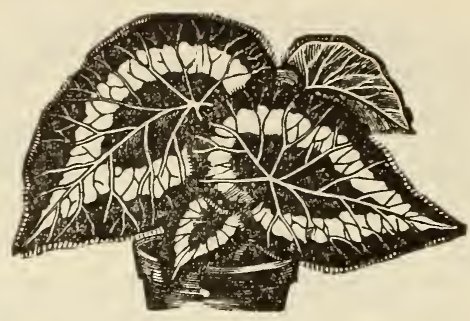

REX BEGONIAS

In no other class of plants do we find colors ranging from bright green to a rich plum color as are found here. Plants are grown exclusively for their unequaled mammoth leaves. 40e each.

\section{HARDY BEGONIA}

A producer of clusters of waxy pink flowers. Can be left out during winter. Thrives anywhere. "Nothing is more satisfactory:" 45 each.

\section{TUBEROUS ROOTED BEGONIAS}

Bears graceful flowers the season through in any nook or corner in complete shade; fine for bedding. Make selection from following colors: Red, Pink, White, Yellow. 40c each; 3 for \$1.15.

\section{DWARF ORANGE}

A true Orange of dwarf habit. Plants, regardless of size, flower and bear fruit. When blooming; plants seem to be all flowers, which emit a delicate yet powerful fragrance. Blossoms are waxy-white. 30c each; larger plants, 60c; extra large plants, $\$ 1.00$.

\section{EVERBEARING LEMON}

Fruit weighing over four pounds has been taken from a tree. Flowers are as fogrant as the orange blossoms which they resemble. For making pies, etc., the fruit excels ordinary lemons. 30e; larger plants, 60c and \$1.00; one Orange and one Lemon for $\mathbf{5 7 c}$.

\section{LANTANAS}

Excellent for bedding as well as for pot or tub culture; make splendid specimens for porch or lawn. Select from following colors: White, variegated vermillion, red, yellowish crimson, lavender. 24c each.

\section{WATERMELON BEGONIA}

Leaves are distinctly variegated white and green, and are thick and waxylike; very interesting. $30 \mathrm{c}$ each.

\section{HOLT'S MAMMOTH GARDEN SAGE}

Leaves 4 to 5 inches long. Prized as an ingredient in soups, salads, etc. Price, nice plants, 20e each; 3 for 57 c.
STRAWBERRY GERANIUM

Exceedingly rare and beautiful. Leaves nearly round are striped silver-white blooms borne on spikes nearly 12 inches high. Price, 25e each; 3 for $72 c$.

\section{BUTTERFLY BUSH OR SUMMER LILAC}

Flowers not unlike the Lilac; blooms from July until cut by frost; it succeeds everywhere and flowers the first season planted and is always attractive. Hardy. Nice plants, 25e each.

\section{PANSY GERANIUM, EASTER}

\section{GREETING}

The color is difficult to describe-a fiery amaranth red; petals are marked with a dark brown or black spot bordered with scarlet penciled with crimson. Price, 35c each.

\section{LEMON VERBENA}

Every garden should have a few plants of this fragrant favorite. Its sweetscented foliage goes well with any flower. Price, 25e each; 3 for $72 c$.

\section{LITTLE GEM FEVERFEW}

The great value of the Feverfew for cut flowers the year around is well known. Flowers are pure white and of perfect form. 20e; 3 for 57c.

ROYAL PURPLE PLANT

A universal favorite. Its foliage surpasses the finest Coleus, Begonia, or Bertolonias in the exquisite colorings of the leaves. $27 \mathrm{c}$ each.

\section{BLUE MOONFLOWER}

A quick, handsome climber. Grows about 20 feet in one season. It flowers in bunches, rich violet blue. Each, 24c. GIANT WHITE MOONFLOWER

Ipomea Maxima. Large fragrant white flowers; rapid grower. Each, 25c.

\section{UMBRELLA PLANT}

An ornamental plant of easy culture; throws up stems about two feet high surmounted with a whorl of leaves. Rivals the Palm for decorating. Nice plants, 25c each; large plants, 50c each. BRAZILIAN PLUME PLANT

Beautiful pink plume-like flowers are borne on ends of long shoots in wonderful profusion. Grown successfully everywhere. 35c each; 3 for $\$ \mathbf{\$ 1 . 0 0}$.

\section{THE COMET PLANT}

Acalpha Sanderii. Leaves are dark green, from the axel of each springs a long, drooping spike of glowing crimson-scarlet, nearly an inch in diameter and from 18 to 24 inches long, resembling a long piece of brilliant chenille. Always in bloom. Price, each, 40c.

\section{SPOTTED CALLA}

The Richardia Alba or Spotted Calla is a magnificent plant. Leaves of the richest green, spotted with pure white. The flowers are white, with delicate chocolate throat. Price, each, 35c; 3 for 95 c.

\section{PLUMiBagos}

Plumbago Capensis. Light blue flowers. Always in bloom.

Plumbago Capensis, Flora Alba. Color is clear white. Price, each, 30c. 


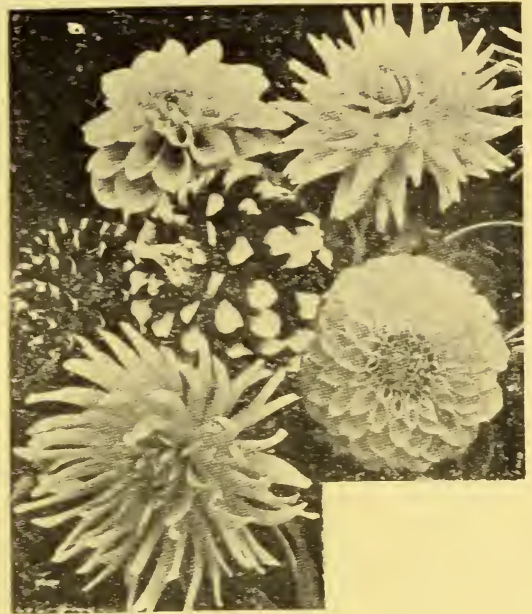

MIXED DAHLIA

\section{D.IHIII ROOTS}

We have purchased the entire collection of choice named Decorative, Show, Peony and other Dahlias from a grower who sold his home and was forced to dispose of his plants. The mixture contains some of the high priced popular varieties. Our price 3 for 45e: dozen, \$1.50: 100 for \$11.00. Mail or express prepaic?

Individed Field clumps. 30c each; dozen, s:3.00 by express not prepaid.

\section{CINYAUON VIXE BULBS}

Beautiful leares, dainty flowers, exquisite perfume, grows in shade or sun, wet or dry. No insects ever trouble.

A charming climber that will quickly surround vour arbor. window or veranda with a wonderful profusion of rines covered with handsome, glossy. heart-shaped leaves, while its clusters of relicate white fiowers emit a delirious fragrance. Very hardy, thriving almost everywhere. though perhaps not so well adapted to the extreme north. The first year the vines run about 10 feet, but eventually reach a height of about 25 to 40 feet. See my "Culture of Flowers" for dire tions" Two or three roots, one foot apart. on each sicle of a door or winclow will quickly cover it. They do best in a warm, sunny location. though thriving almost anywhere.

Extra Quality-Sure to grow. Price. 1 strong root. sie: 3 roots, 2ee: 12 roots 7.e: all postpairl.

\section{FLORICILTIRE GIIDES}

"ClTLTRE OF FLOITERS FROM SEED." Our booklet of practical directions, with special instructions for Asters, Pansies, Swcet Peas, Roses and Greenhouse Seeds, free, if asked for, with an order for flower seeds of $25 \mathrm{c}$ or over. Otherwise, the price is ze. "HOME FLORICULTURE." A guide to srowing seeds, plants and bulbs in the house or garden. A book of 175 pages, all about the puzzling things a flower lover wants to know, gathered from the author's experience of 25 years. Price paper-bound, :3 cents, postpaid.

() ur Leaflets on Aster and on Vegetable seed Culture are free with an order for each, respectively, of 1te or over.

\section{BIRGIIN}

Vegetable follection No. 501 soc

Beans, large packet.

Peas, large packet.

Carrot

Beet

Lettuce, Heart

Lettuce, Leaf

Parsley

Tomato

Rarlish

Spinach

Cucumber

\section{WHITE DIISY}

\section{Imerican Iegion Omicial Flower}

A her of these free blooming annuals should be in every garden. Pkt., 10c.

\section{B.IRG.IIN}

Flower sced Collection No. 502 15 packets Choice Annuals, 50c.

\section{CHHLDIREN'S COHIAECTIOY}

6 packets for 15e: total worth 29c. Popular varieties of easy cultivation. The children may enjoy having their own flower garden.

Ister. Choice mixed.

cosmes. Early. All sharles mixed.

"Hit or Viss" Anmuals. Mixed.

Issturtiums. Mixed colors.

Poppies. Mixed.

sweet Peas, Giants of California. Mixed. 

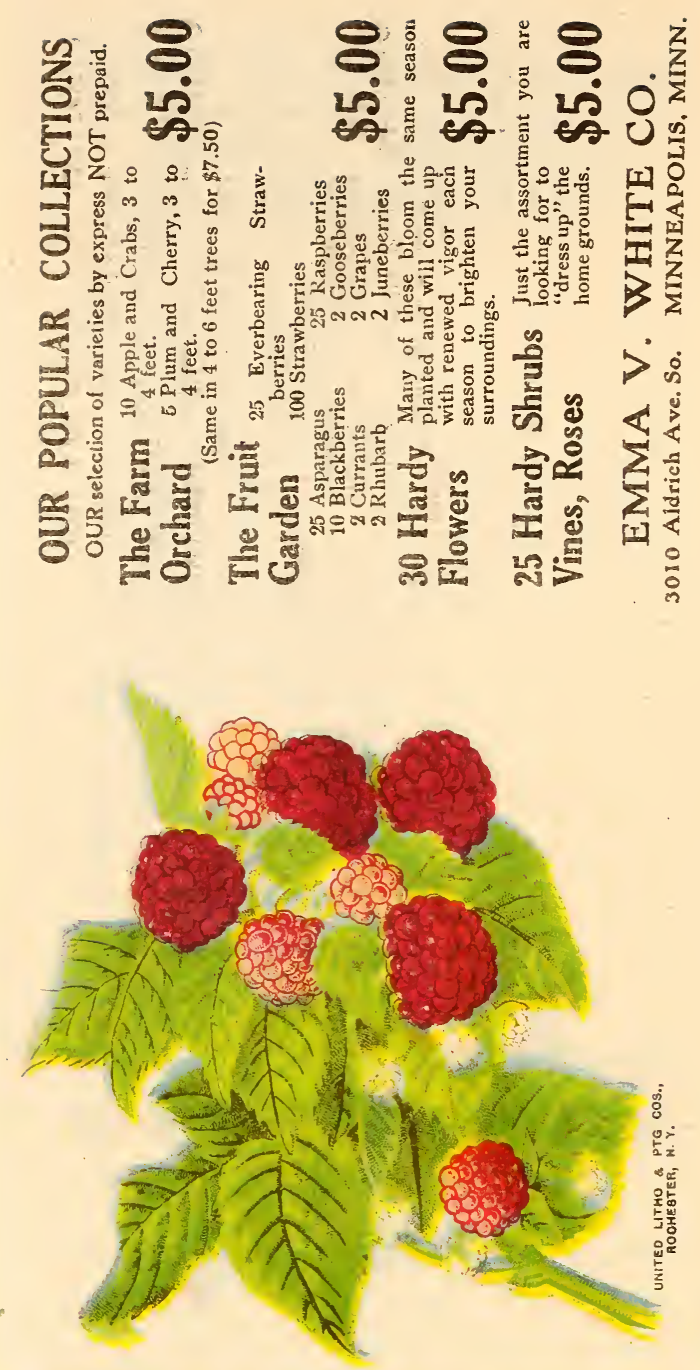

3 Apples 2 years old.

3 Homer (herry (onn roots.)

10 Plum Seedlings, 1 yr.

2 Plum or Cherry 3 to 4 teet.

3 Grapes, assorted.

5 Rhubarb on Pieplant.

50 Asparagus

j0 Raspberies (red.)

25 Błackberries or lewberries.

15 Black Raspberry.

4 Juneberry.

3 High Bush Cranberry.

100 Strawberries, Standard

50 Strawberries, Everbearing.

5 I)ahlias, assorted.

30 Gladiolus. Choice Mired.

15 Gladiolus. Choice Named Sorts.

7 Hardy Perennials, assorted.

7 Hardy Iris.

3) Roses assurted.

5 Hardy t'hlox.

3 Lilacs, assoried.

5 Hardy Lilies.

t Uardy shrubs.

3 Peonites, assorted.

4 Hardy Vines.

4 E ergreen Transplants, 6 to 12 in.

2 Evergreen Transplants, 1:2 to $18 \mathrm{in.}$

10 Bitternut. 12 in.

200 Willow or Poplar Cuttungs

25 Willow or Poplar, $2 \mathrm{ft}$.

100 Bos Elder. 6 to 12 in.

25 Caragana,

25 Russian Olive, “.

4 Ormamental trees, assorted, 3 to $4 \mathrm{ft}$.

4 Niobe Weeping Golden Willow, 3 to $4 \mathrm{ft}$.

\section{EMMA V. WHITE CO.} 3010 Aldrich Ave.So. MINNEAPOLIS. MINN.

ASK FOR OUR NURSERY PRICE LIST 
In the Giarden. Kills all hugs that injure plants.

In the MreInar. Destroys insects injurious to trees.

In the Homsehola. Jixterminates moths, cockroaches, bed-bugs.

In the Ifennel. Feens dogs free from fleas and vermin.

Iu IIe Iomltry aril. Prevents all lice that infest fowl.

Is Indorsed by the Enited States Department of Agriculture and is highly recommended by Florists and Nursery$111+11$.

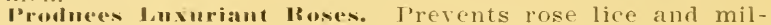
de

Helps to lirow healthy plants and beautiful flowers, and is non-injurious to the tenclerest growth; absolutely safe t() $11: 110 \mathrm{ll} \theta$

'Jhe Cowt Is 'Trifling: 3-oz. calie, Ife. makes $1 \frac{1}{2}$ gallons

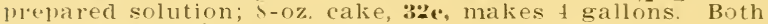
mailed postpaid.

S'I III. So'ICI. With every order for Sulpho Tobacco soap we mail a hooklet. "The Window Garden," by Eben 1:. Rexford, free, giving valuable information on flowers and plants in the house and garden; also helpful hints alout how to exterminate troublesome insects.

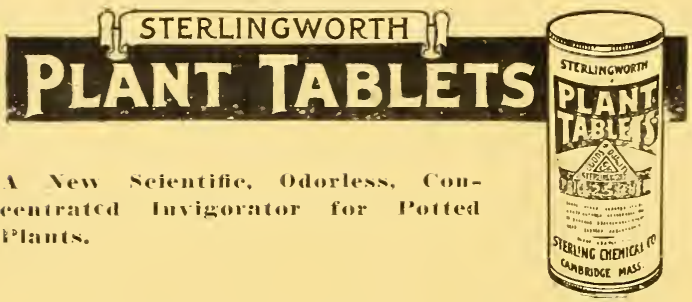

\begin{abstract}
STEIRIIITIURRTH

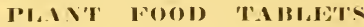
Talies the place of liquid manure. User by dissolving in water. They quickiy start the plants into a healthy and vigorous growth and make them grow and bloom luxuriantly.
\end{abstract}

They are odorless, non-poisonous, uninjurious and are clean and easily handled. and are far superior to plant fertilizers composed of waste material and useless filler. They will make your plants do well.

i'rice, Trial-size Bc x suffeient for jo plants 3 months, 11 e, postnair: lonx sufticient for 35 plants for 3 months, 2!e, postpaid; box sufficient for 35 plants for 5 months, itr. postpaid.

I. I

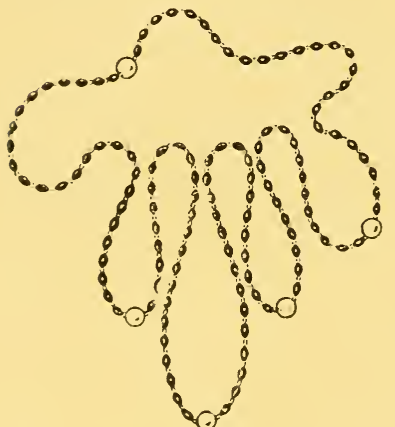

\title{
ICICII I,OPANTHI
}

Beautiful, half-hardy trees or shrubs with finely laciniated foliage and long racemes of small yellow flowers. In the North they can be used as conservatory plants only, lut are perfectly hardy for the Southern states. Before planting, soali seerls in hot water until they swell. The hard, shiny lack seed. either alone or combined with bears. make lovely necklaces. For this purpose they must he soaked in hot water (near boiling) until they swell. They should be strung as they swell and hecome soft. If all do not swell at once, keep the rest soaking in the hot water. After arying. the seerls go back to their natural size and color. Oneralf ounce makes a nice necklace. ['acket, ie: EMMA V. WHITE COMPANY 

